


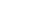




\section{Digitized by the Internet Archive in 2007 with funding from Microsoft Corporation}



$\eta 2$

ELEMENTARY RUSSIAN GRAMMAR 
THE UNIVERSITY OF CHICAGO PRESS CHICAGO, ILLINOIS

THE BAKER \& TAYLOR COMPANY NEW YOBY

THE CAMBRIDGE UNIVERSITY PRESS LONDON

THE MARUZEN-KABUSHIKI-KAISHA TOKYO, OSAKA, KYOTO, PUKUOKA, BENDAI

THE MISSION BOOK COMPANY BEANGHA 


\title{
ELEMENTARY \\ RUSSIAN GRAMMAR
}

\author{
By \\ E. PROKOSCH \\ Bryn Mawr College
}
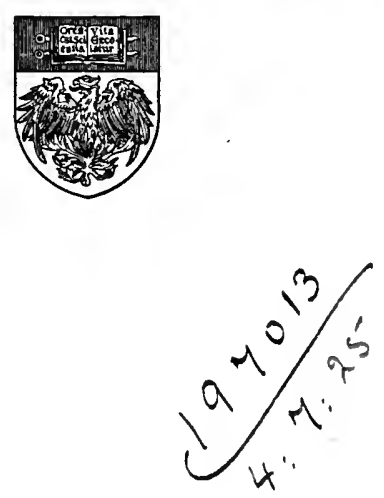

THE UNIVERSITY OF CHICAGO PRESS CHICAGO, ILLINOIS 
Copyright I920 By

The University of Chicago

All Righis Reserved

Published September 1920

Composed and Printed $\mathrm{By}$ The University of Chicago Press Chicago, Illinois, U.S.A. 


\section{PREFACE}

About a year ago the University of Chicago Press invited me to write a brief elementary grammar of Russian with the prime object of introducing the students in a reasonably short time to the reading of simple texts, such as are accessible, for instance, through Harper's adaptation of Boyer-Speranski's Russian Reader.

While I undertook the interesting task with some eagerness, I was well aware of its difficulty. It would have been easy indeed to compile a satisfactory tabulation of rules and paradigms for cursory study and systematic reference, and such a booklet might have proven fairly useful for the needs of traditional "reading" by means of translation. But my ingrained conviction of the limitations of such a study of a modern foreign language turned me from that line of least resistance and made it incumbent upon me to embody even in this modest booklet the most essential features of what is generally termed the "direct method," representing both my theoretical views and the results of twenty years' experience in the teaching of several foreign languages, Russian among them. This implied a number of peculiar complications.

The first requirement consisted in an exposition of Russian pronunciation on a phonetic basis, unavoidably connected with phonetic transliteration. The elusive elasticity of Russian articulation on the one hand, and the need of the greatest simplicity attainable on the other hand, involved many embarrassing problems and demanded considerable deviations from the standard of the Association phonétique, which I should have preferred to adopt in its entirety.

Another feature of the direct method, the inductive presentation of grammatical principles, though apparently beset with serious difficulties in the study of Russian, resulted in some rather interesting simplifications of traditional grammar, especially in the virtual elimination of the numerous declensional classes and the reduction to a minimum of the intricacies of the Russian verb. The frequent conflicts between pedagogical expediency and philological accuracy have almost uniformly been decided in favor of the former; for instance, the imperfective form of the verb is consistently quoted in 
the first place, although the perfective aspect is extremely often the primary, the imperfective aspect the derived, form.

The third essential feature of this method is the oral approach to an elementary vocabulary through object teaching. Given sufficient time and space, this ought to prove unusually attractive in the case of Russian, partly on account of its apparent remoteness from the English vocabulary, partly owing to the morphological vigor of the Russian language. However, in the narrow compass of this primer but meager attention could be devoted to this intrinsically important first phase of vocabulary building. The very few months generally allotted to elementary grammar are also obviously insufficient for the second phase, the accumulation of a more extensive vocabulary through the study of connected texts; the brief selections presented in this book must be supplemented by copious reading from other sources.

Notwithstanding these handicaps the author hopes that his booklet may in a measure help to accomplish these ends: a consciously correct pronunciation, an intuitive feeling for grammatical structure, and, above all, the foundation of an endeavor to read foreign literature, from the simplest to the most involved style, without the crutch of translation. Of course, this presupposes that teachers and students co-operate from the outset in the avoidance of translation, replacing this by intensive study and practice of the texts.

The typographical side of the book should be judged with some leniency, since the typesetting was done by the author himself, for whom this was the first venture into Guttenberg's black art. His crude workmanship was happily mended by the skill and patience of the expert staff of the University of Chicago Press, and he takes pleasure in expressing his thanks for their efficient help. Likewise, he acknowledges a debt of gratitude to the officials and instructors of the Lanston Monotype Company of Philadelphia for their valuable aid in the composition of the book.

Sauk City, Wis.

. E. Prokosch

June 1920 


\section{CON'TEN'TS}

\section{PART ONE-LESSONS}

PAGE

The Russian Alphabet . . . . . . . . . . . . . . 2

TEXT LESBON BECTION

11 1. Stops and Spirants . . . ' . . . . . . 3

2. Voiced and Voiceless . . . . . . . . 3

3. Characteristics of Russian Consonants . . . 3

4. Script Forms . . . . . . . . . . . . 4

5. Table of Consonants . . . . . . . . $\quad$. 5

2 6. The Vowel Triangle . . . . . . . . 6

7. Russian Accented Vowels . . . . . . . 6

3 8. The Sibilants . . . . . . . . . . 7

9. Unaccented Vowels . . . . . . . . . 8

10. Diphthongs . . . . . . . . . . . 9

4 Review . . . . . . . . . . . . 9

11. Consonant Changes . . . . . . . . . 10

12. Vowel Variation . . . . . . . . . . 11

I. The SCHOOL

5 Reading . . . . . . . . . . . . 12

6 13. Gender-Hard Endings . . . . . . . 12

14. Agreement . . . . . . . . . . . 13

7 Questions . . . . . . . . . . . 13

8 15. Palatalization . . . . . . . . . . 14

16. Soft Vowels . . . . . . . . . . . . 15

9 17. Palatalization of Consonants . . . . . . 16

18. Unaccented Soft Vowels . . . . . . . 17

19. Final Palatal Vowels . . . . . . . . 17

10 20. The Hard and Soft Signs . . . . . . . 18

21. Palatalization of Vowels . . . . . . . . 19

11 Review . . . . . . . . . . . . 19

II. The School (continued)

Reading . . . . . . . . . . . . 21

13

22. Gender-Soft Endings . . . . . . . . 21

23. Adjectives, Attributive Endings . . . . . 22

14

24. Possessive Pronouns . . . . . . . . 22

Questions . . . . . . . . . . 23 
III. Teacher and Pupil

25. Present Indicative 24

26. Imperative . . . . . . . . . . . 24

Questions . . . . . . . . . . 25

IV. Objects in the Classroom

V. WRITING

30. Vowel Variation . . . . . . . . . 30

31. Accusative . . . . . . . . . . . 30

32. Instrumental . . . . . . . . . . 30

33. Vowel Variation . . . . . . . . . 30

Questions . . . . . . . . . . 31 Review . . . . . . . . . . . . 31

VI. The Morning

Reading . . . . . . . . . . . . 32

36. Reflexives . . . . . . . . . . . 35

Questions . . . . . . . . . 36

VII. The House

Reading . . . . . . . . . . . . 36

37. Plural of Nouns . . . . . . . . . . . 38

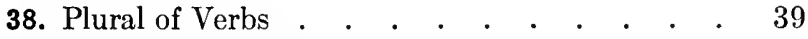

31 39. Plural of Adjectives . . . . . . . . . 40

40. Plural of Pronouns . . . . . . . . . . 40 Questions . . . . . . . . . . 41

VIII. The Divisions of Time

Reading . . . . . . . . . . . . 41

34 41. The Cardinals . . . . . . . . . . 43

35 42. The Ordinals . . . . . . . . . . . . 44

43. Lengthened Noun Stems . . . . . . . 44 
IX. A. Winter-B. The Russian Language

44. Irregular Plurals . . . . . . . . . 47

45. Personal Pronouns . . . . . . . . . . 48

46. Definitive Pronouns . . . . . . . . 48 Review

X. Two Anecdotes

41

42

43

44

45
Reading

47. Formation of the Present

48. First Conjugation, Vocalic Class

49. First Conjugation, Consonantic Clas

50. Consonant Softening

51. Predicative Comparative . . . . . . . 54

52. Adverbs . . . . . . . . . . . . 54

XI. Peter I and the Peasant

48

54. Presents with Consonant Softening . . . . 57

55. Imperative . . . . . . . . . . . 58

49

50

57. Attributive Comparative . . . . . . . 60

58. Possessive Adjective . . . . . . . . . 61 Questions

XII. The Sick Tsar

60. The Past Tense. Questions

XIII. The Squirrel AND the Wolf

62. Simple and Compound Verbs

XIV. The Wolf and the Cat 
XV. Mothers' Tears

63

Reading

PAGE

64

66. The Future

XVI. The Two Peasants and the Cloud

65

Reading . . . . . . . . . . . . 79

66

67. Verb Prefixes Questions

67

XVII. A Picture

68

Reading . . . . . . . . . . . . 82

69

68. The Verbal Adjectives . . . . . . . . 83

69. The Russian Verb System . . . . . . . 84

PART TWO-SYNOPSIS OF GRAMMAR

LETTERS AND Sounds

BECTION

1. The Russian Language . . . . . . . . . . . . . $\quad$. 89

2. The Russian Alphabet . . . . . . . . . . . . . . . . . . 89

3. Phonetic Transcription . . . . . . . . . . . . . . . . . $\quad$. 89

4. Pronunciation . . . . . . . . . . . . . . . 90

5. Sound Changes . . . . . . . . . . . . . . . 92

6. The Russian Accent $\quad . \quad$. . . . . . . . . . . . . . 92

Declension-The Noun

7. Gender . . . . . . . . . . . . . . . . . 93

8. Case . . . . . . . . . . . . . . . . . . 93

9. Number . . . . . . . . . . . . . . . . . 94

10. Hard and Soft Nouns . . . . . . . . . . . . . . 94

11. Table of Endings . . . . . . . . . . . . . . . . . 94

12. Paradigms . . . . . . . . . . . . . . . . 95

13. Lengthened Noun Stems . . . . . . . . . . . . 96

14. Masculines . . . . . . . . . . . . . . . 96

15. Feminines . . . . . . . . . . . . . . . . 98

16. Neuters . . . . . . . . . . . . . . . 98

The Pronoun

17. Personal Pronouns . . . . . . . . . . . . . . . . . . . . 99

18. Possessive Pronouns . . . . . . . . . . . . . 100

19. Demonstrative Pronouns .. . . . . . . . . . . 100 
SECTION

20. Interrogative Pronouns

21. Relative Pronouns . . . . . . . . . . . . . . 102

22. Indefinite Pronouns . . . . . . . . . . . . . 102

23. Definitive Pronouns. . . . . . . . . . . . 102

24. Predicative Declension . . . . . . . . . . . . . 103

25. Attributive Declension . . . . . . . . . . . . . 104

26. Possessive Adjectives . . . . . . . . . . . . . 105

27. Comparison . . . . . . . . . . . . . . . . 106

The Numeral

28. The Cardinals . . . . . . . . . . . . . . . 107

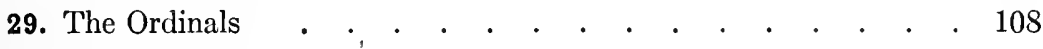

The Preposition

30. Prepositions

Conjugation-The Verb

31. The Two Conjugations . . . . . . . . . . . 110

32. The First Conjugation . . . . . . . . . . . . 110

33. The Second Conjugation . . . . . . . . . . . . 111

34. Irregular Presents . . . . . . . . . . . . . . 111

35. The Imperative . . . . . . . . . . . . . . . . . 112

36. The Infinitive . . . . . . . . . . . . . . . 112

37. The Past Tense . . . . . . . . . . . . . . 112

38. The Verbal Adjectives . . . . . . . . . . . . . 112

39. Perfective and Imperfective Aspect . . . . . . . . 113

40. Definite and Indefinite Aspect . . . . . . . . . . 113

\section{VOCABULARIES}

Special Vocabularies for Texts I-VIII . . . . . . . . $\quad 117$

Vocabulary for Lesson XXXVII . . . . . . . . . . . 122

General Vocabulary . . . . . . . . . . . . . . . 123 


$$
\text { , }
$$


PART ONE

\section{LESSONS}




\section{'THE RUSSIAN ALPHABE'T}

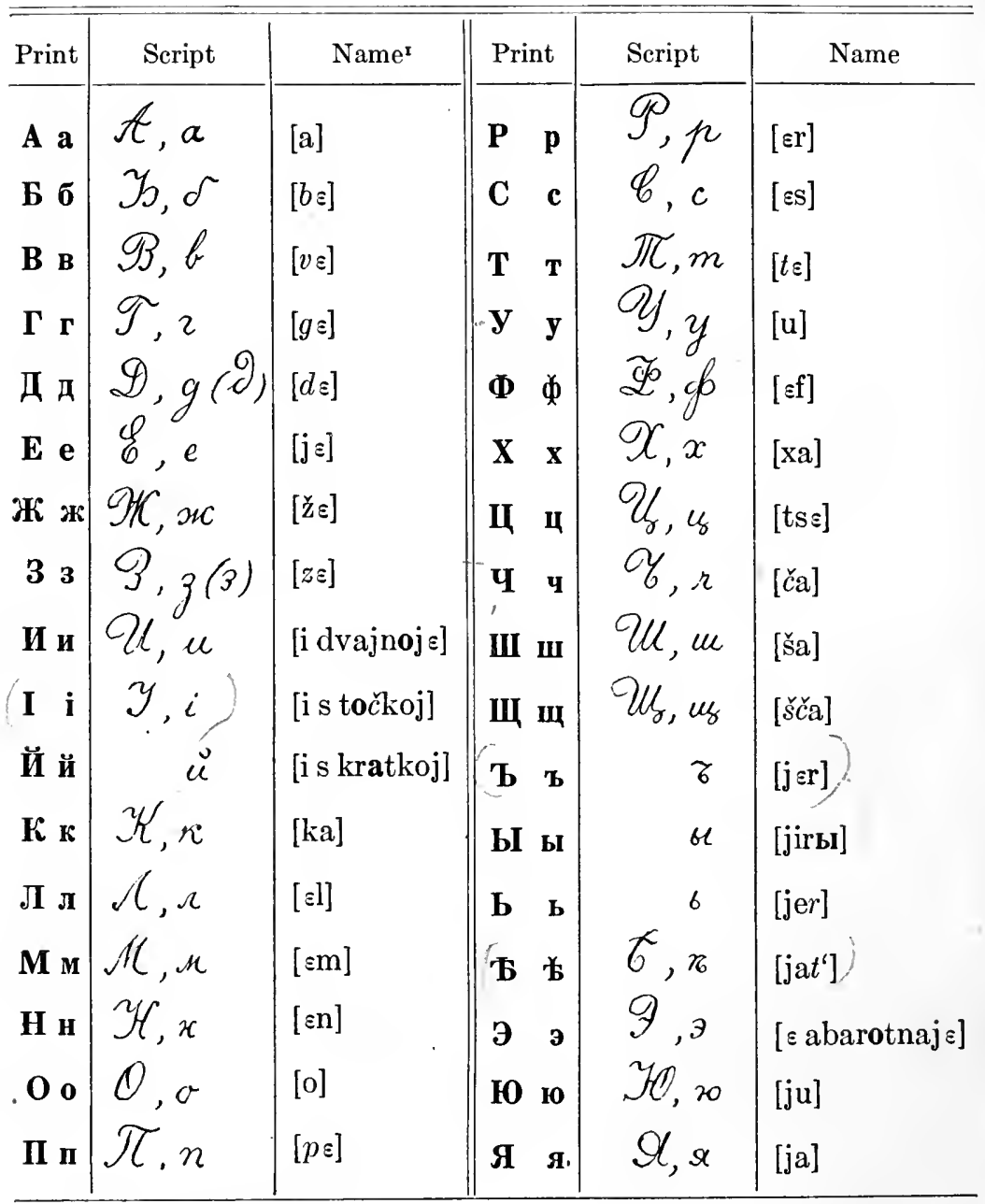

1 Phonetic signs; see I 3 and I 4 . 


\section{ПЕРВЫЙ УРОКЂ}

\section{First Lesson}

Phonetic Transcription. In Russian, as in most languages, traditional spelling represents the sounds of the language in a very imperfect way. For this reason, this book uses a phonetic transcription, based on the system of the International Phonetic Association. Each letter of this system denotes approximately the same sound under all conditions and in all languages.

Phonetic transcriptions are set in brackets: [...].-Accented vowels are set in bold-face type.

References. Bold-face figures refer to the sections of Part One, light-face figures preceded by I, to Part Two of the book.

\section{THE NORMAL CONSONANTS}

1. Stops and Spirants.-Consonants are called stops if the breath is entirely stopped in the mouth, either by closing the lips, or by pressing the tongue against the teeth or the roof of the mouth. The English stops are: $p, b, m ; t, d, n ; k, g, n g$. With spirants, on the other hand, the breath passes through a narrow passage in the mouth. The English spirants are: $w, f, v ; t h, s, z ; s \dot{h} ; l, r ; l$ and $r$ are often called liquids; $s, z$, and $s h$ are termed sibilants.

2. Voiced and Voiceless.-Before entering the mouth the breath passes between the vocal chords, a pair of cushion-like, elastic ligaments in the throat (larynx). If the vocal chords touch one another, the breath causes them to vibrate; the sound of these vibrations is called 'voice,' and speech sounds accompanied by such vibrations are termed voiced sounds; if the vocal chords move apart, the breath passes between them without vibration and produces voiceless sounds.

The English consonants $b, d, g, m, n, n g, v$, th (in then), $z, l, r$ are voiced; $p, t, k, c, f$, th (in thin), $s$, sh are voiceless.

\section{Characteristics of Russian Stops and Spirants.}

Note.-Pronounce Russian $\mathbf{a}=[\mathbf{a}]$ like $a$ in far, $\mathbf{y}=[\mathbf{u}]$ like oo in foot, $\mathbf{0}=[\mathbf{0}]$ like $\boldsymbol{o}$ in Lord, $\mathbf{и}=[\mathbf{i}]$ like $e e$ in meet. $\mathbf{\mathbf { b }}$ is never pronounced. Bold-face type denotes accent. 
(1) English $p, t, k(c)$, especially in initial position, are aspirated voiceless stops, i.e., they are followed by an audible breath, like a weak $h$ : pool, tool, cool $=[\mathrm{p}(\mathrm{h}) \mathrm{u}: \mathrm{l}, \mathrm{t}(\mathrm{h}) \mathrm{u}: \mathrm{l}, \mathrm{k}(\mathrm{h}) \mathrm{u}: \mathrm{l}]$. But Russian II, T, $\mathbf{k}$, like French, Italian, Spanish [p, t, $\mathrm{k}]$, are pure, or without this $h$ : полъ, тамъ, гакъ $=$ [pol, tam, kak].

(2) $\boldsymbol{\sigma}, \boldsymbol{д}, \boldsymbol{\Gamma}=[\mathrm{b}, \mathrm{d}, \mathrm{g}]$ are uttered with more 'voice' than English $b, d, g$ : буду, домъ, гага $=[\mathrm{budu}, \mathrm{dom}$, gaga $]$.

(3) The Russian spirants $\boldsymbol{\phi}, \mathbf{B}, \mathbf{c}, \mathbf{3}$ correspond exactly to English $f, v, s, z$ : футъ, воду, сонъ, зима = [fut, vodu, son, zima].

(4) Russian voiced stops (except the nasals $\mathbf{M}, \mathbf{H}=[\mathrm{m}, \mathrm{n}]$ ) and spirants become voiceless when final or before voiceless consonants: губъ, водъ, радъ, могъ, разъ, губка, водка, разка, лавка = [gup, vot, rat, mok, ras, gupka, votka, raska, lafka].

(5) Russian $\mathbf{T}, \mathbf{д}, \mathbf{H}=[\mathrm{t}, \mathrm{d}, \mathrm{n}]$ are 'pure dentals': the tip of the tongue touches the upper (or upper and lower) teeth as in French, instead of the roof of the mouth, as in American English.

(6) $\mathbf{x}=[\mathrm{x}]$ is like Spanish $j$ in bajo (somewhat weaker than German ch in Bach). To learn it, pronounce hoot and sharpen the $h$ by slightly raising the tongue towards the soft palate: [hut...xut] $=$ худъ.

$\mathbf{K}$ before $\mathbf{T}$ and $\boldsymbol{\varphi}$ is also pronounced $[\mathbf{x}]$ : кто $=[\mathrm{xto}]$.

In a small number of words, e.g., in Бога 'God's', благо- 'well', когда 'when,' $\mathbf{r}$ has the sound $[\gamma]$, like $g$ in North-German wagen, bogen. To learn it, pronounce $f-v, s-z$, th (in thin) - th (in then), and add the analogous pair of voiceless and voiced 'guttural' spirants $[\mathrm{x}-\gamma]$ : [bo $\gamma \mathrm{a}$, bla $\mathbf{a} \mathrm{a}, \mathrm{ka \gamma da}] .-\mathbf{r}$ before voiceless consonants and in the word Богъ 'God' has the sound [x]: легкко = [lixko].

(7) The Liquids.-Russian $\boldsymbol{\Omega}$ resembles American $l$ : The tip of the tongue articulates towards the roof of the mouth, behind the upper gums, barely touching it, and the back of the tongue is strongly (more so than with American $l$ ) raised towards the soft palate. The front half of the tongue is decidedly 'hollow': ловъ, столъ, полъ, стулъ $=[$ lof, stol, pol, stul $]$.

Russian $\mathbf{p}$ is 'trilled tongue tip-r': The tip of the tongue is pressed against the upper gums, and a forceful current of breath causes it to vibrate: разъ, ротъ, трудъ, грубъ $=$ [ras, rot, trut, grup].

4. Script Forms.-The written forms of $A, D, E, K, M, O, a, e, i, o, z$ are the same in the English and Russian alphabets. The script forms of English $B, C, P, T, U, X, b, c, g, m, n, p, r, u, x, y$ occur with different meanings. The other script characters are peculiar to the Russian alphabet, although 'some of them resemble certain English letters. 
Read and copy the following several times, referring to the table of the Russian alphabet on page 2 :

Kagy, naba, nana. Hygy, dadka; dodro. Zymms, goazans, scoge. Bama, barows, boms.

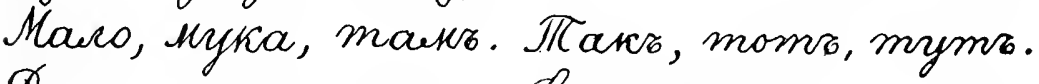
Dama, gocka, gyma. Bygr, cydorma, cagr.

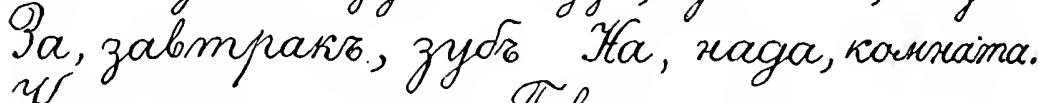
Momo, kyga, naika. Tobopro, wagons, norga.

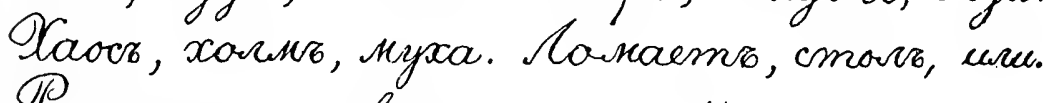

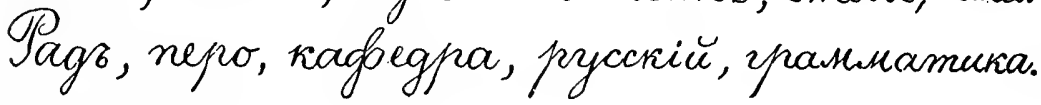

\section{Table of Consonants:}

\begin{tabular}{|c|c|c|c|c|}
\hline \multirow{2}{*}{ SoUnd } & \multirow{2}{*}{$\begin{array}{c}\text { ApProxi- } \\
\text { MATE } \\
\text { ENGLISH } \\
\text { EQUIVALENT }\end{array}$} & \multirow{2}{*}{$\begin{array}{c}\text { RUSsian } \\
\text { LETTER }\end{array}$} & \multicolumn{2}{|c|}{ Russian Instances } \\
\hline & & & Orthographic & Phonetic \\
\hline $\begin{array}{l}{[\mathrm{p}]} \\
{[\mathrm{b}]} \\
{[\mathrm{f}]} \\
{[\mathrm{v}]} \\
{[\mathrm{m}]}\end{array}$ & $\begin{array}{l}\text { grape } \\
\text { bat } \\
\text { fat } \\
\text { vat } \\
\text { mat }\end{array}$ & $\begin{array}{l}\text { II (б) } \\
\sigma \\
\phi(B) \\
\text { B } \\
\text { M }\end{array}$ & $\begin{array}{l}\text { паду, рабъ } \\
\text { буду } \\
\text { футъ, ловъ } \\
\text { вата } \\
\text { матъ }\end{array}$ & $\begin{array}{l}\text { [padu, rap] } \\
\text { [budu] } \\
\text { [fut, lof] } \\
\text { [vata] } \\
\text { [mat] }\end{array}$ \\
\hline $\begin{array}{l}{[\mathrm{t}]} \\
{[\mathrm{d}]} \\
{[\mathrm{s}]} \\
{[\mathrm{z}]} \\
{[\mathrm{l}]} \\
{[\mathrm{r}]} \\
{[\mathrm{n}]}\end{array}$ & $\begin{array}{l}\text { rate } \\
\text { date } \\
\text { seal } \\
\text { zeal } \\
\text { lot } \\
\text { rot } \\
\text { not }\end{array}$ & $\begin{array}{l}\text { T ( }) \\
\text { म } \\
\mathrm{c}(3) \\
\mathrm{s} \\
\mathrm{J} \\
\mathrm{p} \\
\mathrm{H}\end{array}$ & $\begin{array}{l}\text { такъ, пудъ } \\
\text { дама } \\
\text { садъ, разъ } \\
\text { задъ } \\
\text { ловъ } \\
\text { роть } \\
\text { ну }\end{array}$ & $\begin{array}{l}\text { [tak, put] } \\
\text { [dama] } \\
\text { [sat, ras] } \\
\text { [zat] } \\
\text { [lof] } \\
\text { [rot] } \\
\text { [nu] }\end{array}$ \\
\hline $\begin{array}{l}{[\mathrm{k}]} \\
{[\mathrm{g}]} \\
{[\mathrm{x}]} \\
{[\gamma]}\end{array}$ & $\begin{array}{l}\text { lake } \\
\text { give } \\
\text { (bajo) } \\
\text { (wagen) }\end{array}$ & $\begin{array}{l}\mathrm{K} \\
\mathrm{r} \\
\mathrm{x} \\
\mathrm{r}\end{array}(\kappa, \Gamma)$ & $\begin{array}{l}\text { купа, другъ } \\
\text { губа } \\
\text { муха, кто, Богъ } \\
\text { Бога }\end{array}$ & $\begin{array}{l}\text { [kupa, druk] } \\
\text { [guba] } \\
\text { [muxa, xto, box] } \\
\text { [bora] }\end{array}$ \\
\hline
\end{tabular}

The sound of English $n g$, as in sing, does not exist in Russian. 
II

ВТОРОЙ УРОКЬ

Second Lesson

THE NORMAL VOWELS

6. The Vowel Triangle.-In the following diagram the place of each vowel sign designates the position to which the back of the tongue is raised in the pronunciation of that vowel.

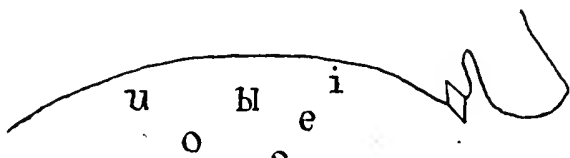

0

$\varepsilon$

a

\begin{tabular}{|c|c|c|}
\hline Sign & Instance & Description \\
\hline [i] & Ger. nie, Fr. dit & Narrower than ee in deed \\
\hline$[\mathbf{e}]$ & Ger. See, Fr. été & $\begin{array}{l}\text { Narrower than } a \text { in mate, and with- } \\
\text { out diphthongal glide }\end{array}$ \\
\hline$[\varepsilon]$ & Ger. recht, Fr. bête & Between $e$ in bed and $a$ in bad \\
\hline [a] & Engl. far & \\
\hline [0] & $\begin{array}{l}\text { Fr. mort, Ger. Mord } \\
\text { Ger. Boot, Fr. beau }\end{array}$ & $\begin{array}{l}\text { Similar to } o \text { in Lord } \\
\text { oa in boat but without diphthongal } \\
\text { glide }\end{array}$ \\
\hline$[\mathbf{u}]$ & Ger. $M u t$, Fr. ou & $o o$ in $\operatorname{mood}$ \\
\hline$[\mathbf{b}]$ & Russian b & $\begin{array}{l}\text { Sound between Ger. } \ddot{u} \text { in Gliick and } \\
\text { Fr. } e \text { in le }\end{array}$ \\
\hline
\end{tabular}

\section{Russian Accented Vowels:}

Articulation. Russian accented vowels are articulated with more tension of the tongue and lips than English vowels, but with less tension than French vowels. They come closest to German accented vowels, except that with Russian y the lips are not rounded as much as with German $u$.

Quantity. Russian accented vowels are generally half-long (about as in American $\operatorname{man}$ ), unaccented vowels are rather short. The difference in quantity is much less marked than in English.

Accent. Russian accent is one of stress, as in English, not of pitch, as in French. This means that accented syllables are stronger (louder) than unaccented ones. The place of accent is variable; a number of general rules will be given in subsequent lessons. 
Table of Russian Normal (= Non-Palatal) Accented Vowels.

\begin{tabular}{|c|c|c|}
\hline Sound & Letter & Instance \\
\hline [i] & И & ива [iva] \\
\hline [a] & $\mathbf{a}$ & да [da] \\
\hline$[\varepsilon]$ & $\mathbf{3}$ & әто [عto] \\
\hline$[\mathbf{u}]$ & & пудъ [put] \\
\hline [o] & o & поль [pol] \\
\hline [ы] & bI & сынъ [sbin] \\
\hline
\end{tabular}

$\boldsymbol{э}$ is called э оборотное [ع abarotnaj s] 'inverted e.'

ы is called еры [jirы]. To pronounce it, the tongue takes a position intermediate between [i] and [u], though slightly lower. The lips are neutral, i.e., neither withdrawn, as with [i], nor protruded, as with [u].

$\mathbf{b}$, called [jer], is never pronounced ( $\$ 15)$.

Russian [o] is generally 'open,' like $o$ in lord, but in some parts of Russia close [o], as in boat, is heard.

[ы] is very frequently pronounced as a diphthong, [ы-j] (сp. 10), especially at the end of words: вы $=[\mathbf{v ы ]}$ or [vыj].

Pronounce:

[iva, era, ana, omsk, ural] Ива, Эра, Анна, Омскъ, Ураль [igo, etam, abram, omut, us] Иго, этомъ, Абрамъ, омуть, усъ [mir, kups, mal, mok, muxa] Міръ, купэ, малъ, могъ, муха [milo, mыlo, mul; bil, bыl, bulka; pilka, pыl, puk; sыn,.sыnы] мило, мыло, мулъ, биль, быль, булка, пилка, пылъ, пук, сынъ, сыны.

\section{III}

\section{ТРЕТІЙ УРОКЬ}

8. The Sibilants.-In addition to $\mathbf{c}$ and $\mathbf{3}$ Russian possesses the following sibilants:

\begin{tabular}{|c|c|c|c|}
\hline Sound & $\begin{array}{c}\text { Approximate English } \\
\text { Equivalents }\end{array}$ & Letter & Instance \\
\hline $\begin{array}{l}{[\mathrm{ts}]} \\
{[\check{s}]} \\
{[\check{z}]} \\
{[\check{c}]} \\
{[\check{s}]} \\
{[\check{s} \bar{c}]}\end{array}$ & $\begin{array}{l}t s \text { in hats } \\
s \text { in sure } \\
s \text { in measure } \\
\text { ch in chin } \\
\text { sh-ch in fish chowder }\end{array}$ & $\begin{array}{l}\mathbf{~} \\
\mathbf{I I} \\
\nVdash \\
\mathbf{4} \\
\mathbf{u}\end{array}$ & $\begin{array}{l}\text { цугъ [tsuk] } \\
\text { шапка [šapka] } \\
\text { жарко [žarko] } \\
\text { чинъ [čin] } \\
\text { пица [pišča] }\end{array}$ \\
\hline
\end{tabular}


The sibilants ц, ш, $\boldsymbol{ж}$ (but not c, 3, ч, щ) have a muffling effect upon a following $\mathbf{и}$, giving it a sound between [i] and [ы], resembling German wide $\ddot{u}$ in Glïck. In English, many speakers use a similar sound for $i$ before [ $\check{s}$ ], especially after $r$ and in unaccented syllables: Frisian, attrition, childish; also before $l$ : milk, children. Our transcription indicates this muffled и by the sign [i].

Pronounce:

[tsatsa, tsuk, tsïrk, tsïkl] [šak, šapka, škola, šïna, šïlo] [žaba, žarko, žïvo, žïža, žïl] [čas, často, čudo, čugun, čin] [ščuka, rošča, pi

Цаца, цугъ, циркъ, циклъ

Шагъ, шапка丿, пкола, шина, шило Жаба, жарко, живо, жижа, жиль Часъ, часто, чудо, чугунъ, чинъ ІІука, роща, пища, борщъ, щи.

\section{Copy :}

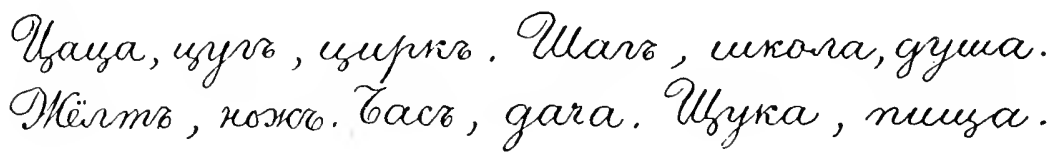

9. Unaccented Vowels.-In Russian, as in English, unaccented vowels are more or less 'slurred.' Much depends upon the rate of speech and upon emphasis, but the following broad statements fairly represent the average usage:

(1) With unaccented vowels, the muscles of the tongue, cheeks, and lips are less tense than with accented ones.

Since all accented vowels are set in bold-face type, it will be understood that vowels in light type are more or less slurred, and no special signs are necessary to indicate this.

(2) In unstressed syllables the tongue tends to assume the Russian 'basis of articulation' (the favorite position of the tongue, 15): With back vowels (compare diagram on page 6) the tongue is apt to be lowered, with front vowels it is apt to be raised. Therefore:

Unaccented $\mathbf{o}$ tends to become [a]: доска $=$ [daska].

Unaccented e tends to become [i]: перо $=$ [piro].

Unaccented a after ц, ш, $\approx$ moves in the direction of the 'muffled' vowel [ï]: шажіокъ, жара $=$ [šižok, žïra].

Unaccented a after ч, щ approaches [i], or at least [e]; our transcription uses the sign [I], to represent this slurred, intermediate vowel: часокъ $=[\check{c}$ Isok $]$. 
(3) This weakening is least noticeable with final vowels and most marked with vowels that precede the accent by more than one syllable. For instance, the word сло́во (nominative) can be easily distinguished from сло́ва (genitive), if pronounced slowly: [slovo, slova]. But in fluent speech the two forms are pronounced alike, [slova]; головá is pronounced [golova, galova, galava, gəlava] ( $\partial=e$ in mother), according to the rate of speech.

NoтE.-The distribution of accent appearing in the last example differs from English habits. In Russian голова the ratio of stress is $1: 2: 3$, while in English grenadier it is $2: 1: 3$.

The vowels $y$ and 9 remain practically unchanged in unaccented position.

Practice:

(1) [daska, akno, patalok, (patolok, pətalok), astro, visako, eta (eto), slova (slovo), xarašo (xarošo, xərašo), piro, kafidra, čirna, čısok, žïlta, ščržu, šĭ̌̌ok, žïra, tsïrapal, dača, kaša, naša, tožs].

(2) доска, окно, потолокъ, остро, высоко, это, слово, хорошо, перо, кафедра, черна, часокъ, желта, щажу, царапаль, дача, каша, наша, тоже.

10. Diphthongs.-The second element of all genuine Russian diphthongs is $\mathbf{и}$, called и съ краткой [i skratkoj] 'ee with the breve' corresponding to $y$ in English boy: май, мой, пожалуй, нашей $=[\mathrm{maj}$, moj, pažaluj, našej].

\section{IV \\ ЧЕТВЕРТЫЙ УРОКЬ}

REVIEW

\section{Consonants}

1. Unaspirated п, т, к: полъ, палъ, потолокґ, такъ, э́тотъ, кýna, каранда́шъ, кýnно.

2. Pure dentals (д, т, н): тотъ, э́тотъ, домъ, доска́, надъ, ну.

3. Strongly voiced б, д, г: бу́ду, бáбка, да́ма, га́га, гово́ръ.

4. Velar spirants, x, г: хорошо́, хо́лодно, кто, Богъ, Бо́га, бла́го-, когда́.

5. Unvoicing of final voiced stops and spirants: рабъ, грубъ, радъ, го́родъ, другъ, могъ, ла́вка, ра́зка.

6. Trilled tongue tip-r: радъ, разъ, другъ, разгово́ръ.

7. Very hollow л: поль, па́лка, потоло́къ. 


\section{Accented Vowels}

8. The 'Vowel Triangle'-tense articulation: [i-e-e-a-o-u].

9. Russian o is open: домъ, столъ. Russian a is like $a$ in far: садъь, па́лка. The sound of eṕ́ is between [i] and [u], but slightly lower: сыни́, ри́бы.

10. и after ц, шш, ж resembles ы or German wide $\ddot{i}$ : циркъ, жидъ.

\section{Unaccented Vowels}

11. Unaccented vowels are 'wide' (the muscles are relaxed); compare $i$ in bit, $u$ in but, $a$ in artistic, opera.

12. Changes:

Unaccented o sounds like [a]: доска́, xорошо́. •

Unaccented e sounds like [i]: перó, черна́.

Unaccented a and e after ц, ш, ж have the sound [i]]: жарá.

Unaccented a after ч, щ has the sound [I] or [e]: часóкъ.

Final weakened unaccented vowels are less subject to weakening than vowels in other positions.

Practice:

(1) tom, mužïk, vos, zdarova, druga, drava, drugoj, tak, tayda, tam, zatılok, padumal, sprašĩval, maladoj, prombslaf, pašla, maros, bыlo, vdruk, zaxnыkala, galubuška, gavarit, službu, pakrыl, box, patamu, papal, pakazal, žĩvotnırx, vыstupal, xvost, dražit].

(2) том'ь, мужікљ, возъ, здорова, друга, дрова, другой, такъ тогда, тамъ, затылокъ, подумалъ, спрашивалъ, молодой, промысловъ, пошла, морозъ, было, вдругъ, захныкала, голубушка, говоритъ, службу, покрылъ, Богъ, потому, попалъ, показалъ, животныхъ, выступал'ъ, хвостъ, дрожитъ.

11. Consonant Changes.-Neighboring consonants influence each other in all languages (compare English grabbed and wrapped $=$ wrapt), but particularly so in Russian.

1. Assimilation of neighboring consonants, not only within words but also between preposition and noun:

(a) б, Д, r, в, 3 become voiceless before voiceless consonants $(3,4$ : ла́вка, ра́зка).

(b) $\mathbf{c}=[\mathrm{z}]$ before б, д, г: сбыва̊льь, сдалъ, сгораль [zbыval, zdal, zgaral]; съ братомъ, съ даромъ, съ года $=$ [zbratam, zdaram, zgoda]. 
(c) $\mathbf{T}=[\mathrm{d}]$ before б, д, г, з, ж (not before в): отдалъ, отбой, отъ брата, отъ дочки, отъ зари = [addal, adboj, ad brata, ad dočki, ad zari].

(d) $\mathbf{k}=[\mathrm{g}]$ or $[\gamma]$ before $б$, д, г: къ брату, къ дому, къ городу

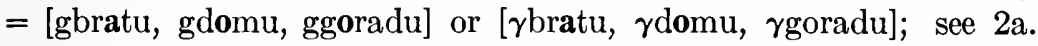

(e) c, $\mathbf{3}=[\check{z}]$ before $ж,=[\check{s}]$ before ч, п, щ: возжелальь, извозчикъ, съ шапкой, съ чортомъ = [važžĭlal, izvoščik, ššapkoj, šcortam] (italics will be explained later).

2. Dissimilation and similar changes.

(a) $\mathbf{K}$ and $\mathbf{r}$ are frequently pronounced $[\mathrm{x}]$ before $\mathrm{T}$ and $\mathrm{K}$, and $[\gamma]$ before б, д, г, i.e., stops before stops turn to spirants: кто, легко = [xto, lixko]; тогда, когда, къ брату $=[\operatorname{ta} \gamma \mathrm{da}, \operatorname{ka\gamma da}, \gamma b r a t u]$.

(b) ч and щ are often pronounced [š] before н: скучно, изящный $=$ [skušno, izjašnurj]. Also in other positions щ is often pronounced [š], especially when the following vowel is unaccented: существо $=$ [sušistvo].—что 'what' is always pronounced [što].

л is silent in солнце [sontse] 'sun.' Also final ль (20) is often silent: рубль [rup]. Д and $\mathbf{r}$ are silent in the groups здн, стн: праздникъ, властный [praznik, vlasnыj].

\section{Vowel Variation:}

Note.-This paragraph need not be studied until referred to in the lessons on declension, where examples will be found. The explanation of these orthographic and phonetic peculiarities belongs to the field of historical grammar.

A. After the velars $(\mathbf{k}, \mathbf{r}, \mathbf{x})$ and the sibilants $\mathbf{ц}, \mathbf{\amalg}, \mathbf{щ}, \boldsymbol{ж}, \mathbf{ч}$ (but not after $\mathbf{c}, \mathbf{3})$ certain vowels are inadmissible:

1. $\mathbf{9}$ and $\mathbf{ю}$ cannot stand after any of them.

2. b may stand after sibilants, but not after velars.

3. ы may stand after ц, but not after any of the other consonants mentioned.

4. o in unaccented endings is permissible after the velars, but not after the sibilants.

Where inadmissible, these vowels are replaced by $\mathbf{a}, \mathbf{y}, \mathbf{z}, \mathbf{u}, \mathbf{e}$.

B. $\mathbf{b}$ after $\mathbf{i}$ is replaced by $\mathbf{и}$. After vowels, $\mathbf{n}$ is used instead of $\mathbf{b}$.

C. Vowel Insertion. Whenever two consonants before final $\mathbf{b}$ or $\mathbf{b}$ would form a group that, for Russian habits of speech, would be difficult to pronounce, $\mathbf{o}$ or $\mathbf{e}$ is inserted between them; generally, $\mathrm{o}$ is used before or after $\kappa, \Gamma, \mathrm{x}$, unless these are preceded by a palatal sibilant. 


\section{ПЯТЫЙ УРОКЪ}

\section{TEXT I}

A

\section{Школа}

Эта комната широка и высока. Окно высоко; потолокъ высокъ.

Вотъ кафедра и стулъ. Вотъ шкапъ. Вонъ окно. Вотъ полъ, вонъ потолокъ. Вотъ доска и палка. Стуль жёлтъ. Кафедра тоже желта.

Вотъ карандашъ, перо и ножикъ. Этотъ карандапгъ жёлтъ, а это перо чёрно. Доска тоже черна. Мой карандашъ тупъ, но это перо остро. Бумага гладка. Столь тоже гладокъ.
B

škola

1. Read column B many times. Cover column A with a strip of paper during the first few times; begin to compare it with column B when your pronunciation is becoming fairly fluent.

2. Read column A many times, at first constantly comparing it with B, but later without this.

3. Copy text A several times in Russian script.

4. Both when reading and writing a sentence, visualize its meaning: Concentrate your thoughts upon the persons, objects, and actions mentioned. But do not indulge in the worse than useless pastime of 'translating' these simple sentences into English. The approximate English equivalents of all words are given in the word-lists at the end of the book, for occasional reference, but it would be a mistake to memorize those lists. Memorize sentences and whole texts as much as you can, but not isolated words.

\section{VI \\ IIЕСТОЙ УРОКЂ}

\section{Gender.-'Hard Endings.'}

Стулъъ, шкапъ, каранда́шъ, нбжикъ, потоло́къ, полъ are masculines. Комната, ка́федра, доска́, бума́га, па́лка are feminines.

Окно́, перб́ are neuters.

The gender of Russian nouns is determined primarily by their endings; ' $, \mathbf{a}, \mathbf{o}$ are called the 'hard' terminations of the masculine, feminine, and neuter respectively. 


\section{Agreement:}

IIIкапъ-высо́къ.

$\vartheta^{\prime}$ тотъ шкапъ.

Доска́-высока́.

Окно́-высоко́.

Э’та доска́.

Э’то окно́.

Вотъ каранда́ш'ъ; онъ тупъ.

Вотъ доска́; она́ широка́.

Вотъ окно́; оно́ высоко́.

The predicate adjectives-высо́къ, -á, -ó; широ́къ, -á, -ó-, the demonstratives-э́тоть, э́та, э́то-, and the personal pronouns-онъ, она́, оно́-are in agreement as to gender and number with the noun which they modify or refer to.

Note.-A dash is often used between subject and predicate noun or adjective, where English would use 'is' or 'are.'

The accent and other peculiarities of predicate adjectives cannot be determined by definite rules, but must be learned by practice; observe carefully the forms given in the word-lists at the end of the book.

With the nouns and adjectives contained in the text, form as many sentences of the type Окно́ высоко́ (subject+predicate adjective) as the sense permits. Speak each sentence before you write it. Mark the accents.

(E.g., Окно́ высоко́. Окно́ широко́. Окно́ гла́дко.)

\section{VII}

\section{СЕДЬМОЙ УРОКЂ}

\section{Questions-Bompócы}

These questions serve a twofold purpose: Aside from familiarizing the student with the more common types of Russian questions, they are intended as a basis for a thorough practice of the text. Each Russian question should suggest one or several Russian sentences as possible answers.

After having read the text often and carefully, read and answer the questions repeatedly. When you can answer them without hesitation, copy them and write the answers.

Make it a habit to mark the accents in writing.

1. Что э́то? (Это ко́мната...стулъ...па́лка...). 2. Какова́ э́та ко́мната? (Она́...) 3. Како́въ э́тотъ шкапъ? 4. Каковó э́то окно́? 5. Како́въ э́тотъ стулъ (потоло́къ, каранда́шъ, но́жикъ, поль)? 6. Какова́ э́та доска́ (па́лка, ка́федра, бума́га)? 7. Каково́ э́то перо́? 8. Что широко́? Что высоко́-жёлтоту́по-остро́-гла́дко? 


\section{VIII}

\section{ВОСЬМОЙ УРОКЂ}

15. Palatalization.--In every language there exists a habitual preference for a certain position of the tongue both when at rest and during the utterance of speech sounds. In English, especially as spoken in America, the tip of the tongue is apt to be withdrawn from the teeth and raised in the direction of the front palate, while the body of the tongue is comparatively inert, being neither raised nor lowered to any marked extent.

Such a preferred position of the tongue is called the 'basis of articulation' of that language.

In Russian the tongue tends to be pushed forward. The tip is likely to be pressed against the lower teeth or gums, and the front third of the tongue approaches or touches the front palate along a considerable stretch. The following diagrams illustrate this contrast between the American and Russian basis of articulation:
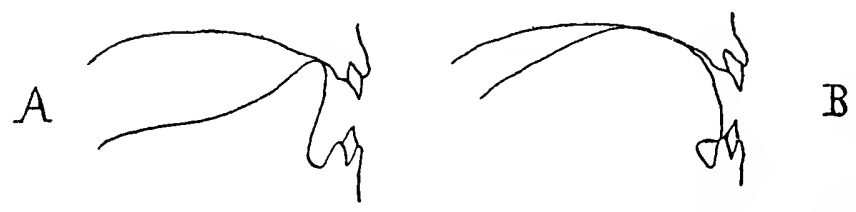

' $\mathrm{A}$ ' shows the articulation of American $n(t, d, l)$, 'B', that of a very frequent type of Russian $\mathrm{H}$ ( $\mathrm{T}, \mathrm{д}, \pi)$, described below.

Position ' $\mathrm{B}$ ' is the typical 'palatal' position of the tongue: Its tip touches the lower teeth or gums, and its back is in contact with a rather large portion of the hard palate.

The tendency towards palatal articulation, i.e., the inclination of the tongue to assume this palatal position, is the most conspicuous characteristic of Russian speech. For a full understanding of its effects it is essential to realize that it is generally not restricted to one sound, but spreads over whole groups of sounds, so that we might speak of palatal syllables rather than of palatal sounds.

It is absolutely necessary to acquire this habit of palatalization, for this tendency, more than anything else, lends to Russian that peculiar pliability which has been called by a well-known phonetician 'the insinuating grace' of Russian. 
16. Soft Vowels.-All Russian vowels exist in pairs: a non-palatal or 'hard' sound and a 'palatal' or 'soft' sound.

The hard vowels have been treated in 7. From the English point of view they may be called 'normal vowels.'

The soft vowels are those that start with the tongue in palatal position. The gradual transition of the tongue to vowel position (6) produces the 'prepalatal spirant' [j], the sound of English $y$ in yes, year. Thus, Russian possesses the following palatal or soft vowels:

$[j i, j e, j \varepsilon, j a, j o, j u]$.

The [j]-glide is distinctly audible when a soft vowel stands at the beginning of a word or after a vowel, thus beginning a syllable, as in ядъ, моя́ [jat, maja]. After a consonant it is less distinct or disappears entirely, as explained in 17.

Table of Accented Soft Vowels:

\begin{tabular}{|c|c|c|c|}
\hline & Sound & Letter & Instances \\
\hline 1. & [ji & $\mathbf{n}, \mathbf{i}$ & имъ, ихъ [jim, jix] \\
\hline 2. & {$[\mathrm{j} \varepsilon]$} & $\mathbf{e}, \mathbf{b}$ & 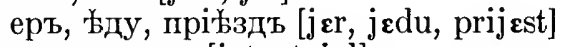 \\
\hline 3 . & {$[\mathrm{j} a]$} & я & ядъ, стояль [jat, stajal] \\
\hline 4. & [jo] & $\ddot{\mathbf{e}}$ & ёжъ, пріёмъ [još, prijom] \\
\hline 5 & [ju] & ю & юбка, пріють [jupka, prijut] \\
\hline
\end{tabular}

1. и is called и двойное [i dvajnoj $\varepsilon$ ] 'double $e e$,' $\mathbf{i}$ is called і съ точкой [i stočkoj] ' $e e$ with the dot,' й (10), и съ краткой [i skratkoj] ' $e e$ with the breve.' Initial и has the [j]-glide only in the words имъ, ихъ, ими [jim, jix, jimi], plural forms of the pronoun of the third person; elsewhere it is [i]: иго, стоить [igo, stait]. $\mathbf{i}$ is used only before vowels, e.g., пріхздъ [prijest], except in the word мірь 'world, community' (but мирь 'peace').

2. The difference between $\mathbf{e}$ and $\boldsymbol{t}$ is a purely orthographical one. Their pronunciation is the same.

3. я corresponds exactly to the hard vowel a, and $ю$ to $\mathbf{y}$.

4. The diacritical mark upon ë [jo] is not used by Russians, but appears quite generally in elementary books for foreigners, as a crutch soon to be discarded. Observation, assisted by a few general rules, will soon teach when accented $\mathrm{e}$ has the sound [jo]. In a few words, e.g., зв'ззды 'stars', гн'ъзда 'nests', accented also pronounced [jo].

Copy:

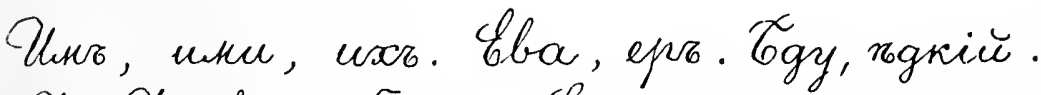

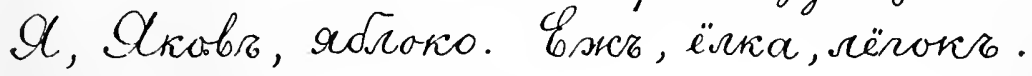
Hpiй, closo, robopro. 
Pronounce:

[jim, jimi, jix]

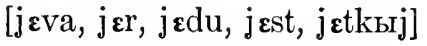

[ja, jakaf, jablako, jama]

[još, jolka, jolačka, jorš, jomkuj]

[jurij, jupka, juk, jurist]
Имъ, импा, ихъ

Ева, еръ, Њду, Һстъ, ьдкій

Я, Яковъ, яблоко, яма

Ежъ, ёлка, ёлочка, ёршъ, ёмкій

Юрій, юбка, югъ, юристъ.

IX

\section{ДЕВЯТЫЙ УРОКЂ}

17. Palatalization of Consonants.-When a consonant is followed by a soft vowel, the tongue assumes palatal position during or before the pronunciation of the former. This affects consonants in different ways:

1. ч, щ, ж, ш are entirely or partly palatal anyway; consequently, a following soft vowel does not influence them.

This is recognized by spelling inasmuch as the letters $я$ and $\mathrm{a}$ and $\mathrm{y}$ after these consonants; see $12 \mathrm{~A} 1$.

2. The Dentals, т, д, н, л, become genuine palatals, with the tongue in the position described in $\mathbf{1 5}$. In the transition to the vowel the contact with the tongue is gradually released so that a rapid [j]-glide is plainly audible before the vowel. Palatal $\mathrm{T}, \mathrm{д}, \mathrm{H}, \pi$ are transcribed by $[t, d, n, l]$, the italic type indicating both the palatal quality of the consonant and the following glide.

To learn the pronunciation of $[t, d, n, l]$ place the tip of the tongue against the lower teeth or gums and bring the back of the tongue in contact with the front pa!ate, as shown in 15; try to pronounce $[t, d, n, l]$ as well as this position permits, and the result will be the articulation of $[t, d, n, l]$. Pronounce: $[t \mathrm{i}, d \mathrm{i}, n \mathrm{i}, l \mathrm{i}$; te, $d \mathrm{e}, n \mathrm{e}, l \mathrm{e} ; t \mathrm{a}, d \mathrm{a}, n \mathrm{a}, l \mathrm{a}]$.

The articulation of $\mathbf{p}$ is not perceptibly influenced by a following soft vowel, but a slight glide is often audible: $[r e, r a, r o, r u]$.

The dental sibilants, $\mathbf{c}$ and $\mathbf{3}$, before soft vowels differ from 'hard' $c$ and 3 merely by a slight lisping; the tip of the tongue touches the lower teeth. The glide is hardly noticeable: [si, zi, se, ze, sa, za, so, $z \mathrm{o}, \mathrm{su}, z \mathrm{u}]$.

Pronounce:

[tixo, dita, ni, litso, ris, six, zima] Тихо, дитя, ни, лицо, рисъ, сихъ

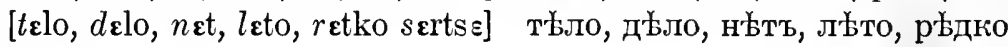


[tapka, sona, lass, rat, sak] тяпка, Соня, лясы, рядъ, сякъ [totka, kladot, logak, birot, sola] тётка, кладётъ, лёгок, берётъ, сёла [turma, dužina, nuxnu, rumka] тюрьма, дюжнна, нюхну, рюмка.

3. The Labials, $\mathbf{I}, \boldsymbol{\sigma}, \mathbf{M}, \stackrel{\phi}{\phi}, \mathbf{B}$, do not change their articulation proper before soft vowels. Nevertheless, the tongue assumes palatal position

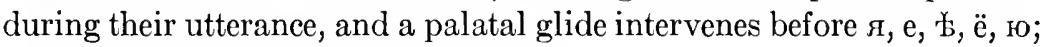
before In it is practically imperceptible.

Pronounce:

[pivo, $p \varepsilon c ̌ k a, p a t a j \varepsilon, p o t r]$ [bil, belыj, bodra, bust] [mir, mera, maso, morzlыj] [fizika, $f \varepsilon p$, fodar, vina, $v \varepsilon s t]$ пиво, печка, пятое, Пётрь

билъ, бълый, бёдра, бюсть миръ, м̌̀ра, мясо, мёрзлый

физика, Фебъ, Фёдоръ, вина, вестъ

4. After the Velars, $\mathbf{\kappa}, \mathbf{\Gamma}, \mathbf{x}$, the soft vowels $я$ and (12 A 1); e after velars is always pronounced [e, $\varepsilon$ ], never [o]; the glide is audible before e, $\mathrm{w}$, but hardly ever before $\mathrm{n}$ :

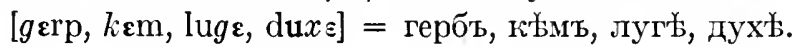

\section{Unaccented Soft Vowels:}

Unaccented

All other unaccented soft vowels approach more or less the sound [ji] if initial, [i] after consonants. Unaccented $\mathrm{r}$, like unaccented a after ч, щ $(9,2)$, is variable: According to the rate of speech it ranges from $[j \varepsilon, \varepsilon]$ in slow, careful utterance to slurred [ji, i]. Our transcription uses the sign [ji, I].

Pronounce:

[jivropa, jimu, jidva, jizda] Европа, ему, едва, Һзда [derivo, diržu, nimu, nečit] дерево, держіу, нему, нечетъ [jadra-jıdro, jızыk, jirmo] ядра-ядро, языкъ, ярмо [još, jižы, sola, silo, stokla] ёжъъ, ежжы, сёла, село, стёкла

19. Final Soft Vowels generally preserve their quality even when unstressed, though in rapid sentence connection final unaccented e, $\mathrm{b}$, and even я, may sometimes appear as [i, I]. Final accented e is always

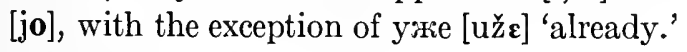

[jiščo, majo, pol $l$, učilišč $\varepsilon, \min \mathbf{a}, d \mathbf{a} d \mathrm{a}$, gavaru, čitaju] ещё, моё, поле, училище, меня, дядя, говорю, читаю. 


\section{$\mathrm{X}$ \\ ДЕСЯТЫЙ УРОКЬ}

20. The Hard and Soft Signs. - $\mathbf{\text { t }}$ and $\mathbf{b}$, called еръ or твёрдый знакъ [jer, tvordыj znak], and ерь оr мягкій знакъ [jer, maxkыj znak], are mere signs of pronunciation. In an early period of the language ъ was a hard vowel, slurred $u$, and b a soft vowel, slurred $i$. At present, $\boldsymbol{B}$ denotes the non-palatal-hard, normal-articulation of the preceding consonant, $\mathrm{b}$ its palatal quality.

NoTE.-The function of $\mathrm{s}$ being a merely negative one, namely, to show that the preceding consonant is not palatalized, it might as well be discarded altogether as has been the practice of some Russian publications for many years. In 1918 the Soviet government declared its complete abolition, together with some other sensible simplifications of spelling, but for an elementary book it seems preferable, for the time being, to retain the old spelling.

With few exceptions, b occurs at the end of words. Its effect is the same as that of a palatal vowel: The tongue is in palatal position during the utterance of the preceding consonant. The results are:

1. The dental stops, $\mathbf{T}$ and $д$, followed by $ь$, become genuine palatal stops, in the sense described in $\mathbf{1 7 , 2}$. The [j]-glide, which is very marked, becomes voiceless in final position; it is indicated by ['] in our transcription. This voiceless glide closely resembles a weak German ch as in $i c h$, or English $h$ in human. Medially, it is a very rapid, halfvoiced glide: суть, будь, судьба $\left[\mathrm{su} t^{6}, \mathrm{bu} t^{t}, \mathrm{sud} d^{\prime} \mathrm{ba}\right] ;$ будьте $=[\mathrm{bu} t \varepsilon]$.

2. Also н and л become pure palatals, just as before palatal vowels, but a slight palatal glide (not indicated in the transcription) precedes them: соль, роль, только, тоныше, лунь, конь, коньки [sol, rol, tolko, tonšs, lun, kon, konki]; соль, конь sound almost like soil, coin, with the $i$ barely suggested.

3. pъ (rare) is weakly trilled or altogether untrilled, and often preceded by a slight glide, like ль and нь: дурь, царь $=$ [dur, tsar $]$.

4. $\mathbf{~ c \mathbf { b }}$ and $\mathbf{3 b}$ are hardly discernible from hard $\mathbf{c}$ and $\mathbf{3}$. There is no perceptible glide, but only a slight palatal affection of the preceding vowel (21). The same is true of пь, бь, фь, вь, мь: моська, Русь, кровь, Обь, семь [mоska, rus, krof, op, sem].

5. After $\Gamma, \kappa, x, ц$ the soft sign does not occur; after ж, пा, ч, щ it is very rare and has no effect whatever.

Pronounce:

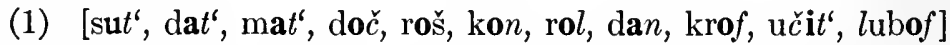

(2) суть, дать, мать, дочь, рожь, конь, роль, дань, кровь, учить, любовь. 
21. The Palatalization of Vowels.-The palatalizing influence of the soft vowels and the soft sign extends even beyond the preceding consonant: It affects the vowel of the preceding syllable.

1. $\mathbf{3}, \mathbf{e}, \mathbf{b}$ are pronounced [e] instead of [z], thus moving in the direction of [i] within the 'vowel triangle': это, секта, Һсть, 'дуу =

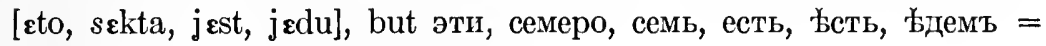
[eti, semira, sem, jest', jest', jedim].

2. Very many Russians pronounce a before hard vowels (in the next syllable) like French $a$ in pas, but a before soft vowels like French $a$ in la: With the former sound, the back of the tongue is slightly raised, with the latter, the front. Our transcription does not indicate this distinction, which is by no means generally observed; however, a trained ear will often perceive the difference between 'back-a' in áвгустъ, да́ромъ, я́года and 'front-a' in а́льбумъ, царь, ня́ня.

3. o, e, y, $\mathbf{0}$ show a well-marked palatal glide $(20,2)$ before palatal $\boldsymbol{\mu}$ and $\mathrm{л}$, but before other consonants their palatal affection is hardly noticeable; the contrast between вонъ and вонь, волъ and воль, is quite obvious, but the shade of difference between объ and Обь, топка and топь, is hard to detect: [von, von, vol, vol, op, op, topka, to $p$ ].

The vowels и and ы are not affected by any following sounds.

Before $u$ and $\amalg$ the pronunciation of accented e, $\mathrm{b}$ is always [e], never $[\varepsilon]$; before $ж, \mathrm{II}, ц, \pi k$ it is always $[\varepsilon]$, never $[\mathbf{e}]$ :

вечеръ, печка, рбчка, вепь, ббжишь, бълка, бълки

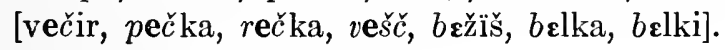

\section{Pronounce:}

[eti, stat, $t$ \&kst, tiper, davolno] [abst, vet', xatet $t^{\prime}$, smatret $\left.t^{t}\right]$ [smatr $\mathbf{l}$, zametili, $\mathrm{m} n \varepsilon$, atvet] [atvetit', direvna, deriva, den] [delo, dele, son, sona, dan, dan]

эти, этотъ, текстъ, теперь, довольно оббдъ, вьдь, хотьть, смотрђть смотрблъ, замбтили, мнъ, отвъть отвђтить, деревня, дерево, день дъло, дьльь, сонъ, соня, данъ, дань.

\section{XI}

\section{ОДИННАДЦАТЫЙ УРОКЂ}

\section{REVIEW}

I. The General Principle of palatalization: The tongue tends to assume the 'palatal position'-tip toward lower teeth, surface touching the front half of the hard palate.

II. Soft or Palatal Vowels: .и, е, †, я, ё, ю. 
A. Initial-Accented [ji, je, ja, jo, ju]. Unaccented: $\mathbf{g}=[\mathrm{jr}]$, $\mathrm{e}, \mathrm{b}=[\mathrm{ji}]$ :

пмъ, еръ, ‘'ду, ядъ, ёжъ, югъ; ядро́, ери́, łзда́.

(ë is always accented; in unaccented position it is replaced by $\mathrm{e}=[\mathrm{i}]$.)

B. Medial-Palatalization of Consonants.

1. т, д, л, н followed by soft vowels become genuine palatals, transcribed by $[t, d, n, l]$; the italic type signifies both the change of articulation and the palatal glide after the consonant.

2. p, c, 3, п, б, ф, в, м remain virtually unchanged, but a slight [j]-glide is heard before the vowel (indicated by italic type for the consonant): рбдко, Пётръ, бълый, мясо, Фёдоръ, вестъ $=[r \varepsilon t k o$, potr, $b$ \&lыj, maso, fodar, $v \varepsilon s t]$.

3. The glide before [i] is hardly perceptible, except after $\mathrm{T}, \mathbf{д}, \mathrm{H}$ : [tixo, dita,] but [piwo, six].

C. Final-Final soft vowels are unchanged even when unstressed: дядя, зданіе, поль, дъълаю, = [da $d \mathbf{a}$, zdanij $\varepsilon, p o l \varepsilon, d \varepsilon l a j u]$.

III. The Soft Sign. The hard sign, $\mathbf{b}$, merely denotes the absence of palatalization; the soft sign, $\mathbf{b}$, palatalizes final (rarely medial) consonants:

1. Voiceless glide after ть, дь: есть, будь $=\left[\mathbf{j e s t} t^{6}, \mathrm{but} t^{t}\right]$.

2. нь and ль are distinctly palatal, рь, сь, зь are slightly palatal, the other consonants before $\mathrm{b}$ are non-palatal.

3. The palatal affection of $[\mathrm{o}, \mathrm{u}]$ is distinct before нь, ль, but very slight before other consonants and $\mathbf{b}$.

IV. Palatalization of Vowels. Accented e, b, э before palatals = [je, e]. Accented a, я before palatals is often 'fronted' (like French $a$ in $l a$ ). Other vowels show a slight palatal glide: э́ти, есть, 'ьсть, семь, царь, ня́ня, только, Русь.

Practice:

[loš, dveri, živuščij Јожь, двери, живущее, слёзы, звъ'зды, спаси́, меня́, то́лько, её, ей,

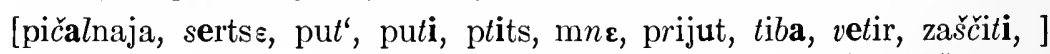
печа́льная, се́рдце, путь, пути, птицъ, мнъ, пріютъ, тебя, ветьрьз,за[prasba, sud'ba, znajiš, vdvajom, atvetili, budiš, glavoju, stoit] щити, просьба, судьба, знаешь, вдвоёмъ, отвђтили, будешь, главою [tvaim, jimi, ani, atčajınije, načrlo, načalo, gavarili, bratım, стонтъ, твоимъ, ими, они, отчаяніе, на́чало, нача́ло, говорили, [staniš, zimla, zemlu]

братьямъ, станешь, земля, землю. 
XII

ДВБНАДЦАТЫЙ УРОКЂ

\section{TEXT II}

\section{Учили ще}

Это болышое зданіе-школа или учнлище. Я-учитель. Моё имя-Владимирь; моя фамиліяЧеховъ. Вы-ученикъ; онаученица. Я учу, а вы учитесь. Вы хотите изучать русскій языкъ.

Вотъ моя книга. Эта книгарусская грамматика. Вотъ русско-англійскій словарь. Моя грамматпка тонка іг легка, но мой словарь большой. Ваша тетрадь тонка и легка.

имъ, ихъ, или, хотите, книга есть, Һстъ, ьду, какое, зданіе я, имя, моя, русская, большая моё, ещё, своёмъ, жёлтый даю, какую, девлаю, говорю.

\section{učilišč $\varepsilon$}

eta balšoje zdanijø — škola

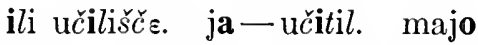
ima - vladimir; maja familija - čеxaf. vы - učinik. ana - učinitsa. ja uču, a vы učitis. уы хаtitє izučat ruskыj jızыk. vot maja kniga; sta kniga ruskaja gramatika. vot ruskaangliskыj slavar. maja gramatika tanka i lixka, no moj slavar balšoj. vaša titrat tanka i lixka.

jim, jix, ili, xatit $\varepsilon, k n i g a$ jest', jest, jedu, kakoj $\varepsilon$, zdanij $\varepsilon$ ja, ima, maja, ruskaja, balšaja majo, jiščo, svajom, žoltıj daju, kakuju, delaju, gavaru.

Read both text columns repeatedly; read the phonetic practice following them; return to the text and read it until you have achieved perfect fuency. Then copy the left-hand column.

\section{XIII}

\section{ТРИНАДЦАТЫЙ УРОКЬ}

22. Gender.-Soft Endings. (Hard endings, see 13.)

Masculines
учи́тель
слова́pь
геро́й hero
бой fight

Feminines
тетра́дь
дверь door
фами́лія
а́рмія army

Neuters зда́ніе учи́лище по́ле field и́мя

1. Nouns in $\mathbf{b}$ or $\ddot{\mathbf{n}}$ are masculines.

2. Nouns in $\mathbf{a}$ or $\boldsymbol{g}$ are feminines.

3. Nouns in $\mathbf{b}$ are either masculines or feminines.

4. Nouns in $\mathbf{0}, \mathbf{e}, \mathbf{м я}$ are neuters. 
23. Adjectives.-Attributive Endings. (Predicative endings, see 14.)

Masc. Слова́рь толстъ. То́лстый слова́рь, си́ній слова́рь.

Fem. Кни́га толста́. То́лстая кни́га, си́няя кни́га.

Neut. Зда́ніе высоко́. Высо́кое зда́ніе, си́нее зда́ніе.

A. Зда́ніе высоко́ The building is high.

Predicative adjectives have practically the same endings as nouns: $\mathbf{b}, \mathbf{b}-\mathbf{a}, \mathbf{g}-\mathbf{0}$, e.

a. The predicative form of soft adjectives, especially for the masculine, is used very rarely. Большо́й and adjectives in -скій (ру́сскій, а́нглійскій) have no predicative forms.

b. Notice these accent types of predicative adjectives:

The accent remains on the stem: здоро́въ, здорб́ва, здорб́во healthy.

The feminine stresses the ending: мо́лодъ, молода́, мо́лодо уоung; гла́докъ, гладка́, гла́дко; новъ, нова́, но́во nеw.

The accent is on the last syllable in all forms: ширб́къ, пиярока́, широко́; высо́къ, высока́, высоко́; тяжёлъ, тяжела́, тяжело́; остёръ, остра́, остро́; тупъ, тупа́, тупо́.

В. Вотъ то́лстый слова́рь.

То́лстый is an attributive adjective. Attributive adjectives have these endings for the Nom. Sing.:

\begin{tabular}{llcc} 
& \multicolumn{1}{c}{ м } & F & N \\
Hard: & ый, (ій), ой & ая & ое \\
Soft: & ій & яя & ee
\end{tabular}

то́лстый, то́лстая, то́лстое широ́кій, шпро́кая, широ́кое

большой, болша́я, болышо́е си́ній, си́няя, си́нее

a. The accent of attributive adjectives remains on the same syllable in all forms.

b. The hard masculine ending is ой, if it is accented.

c. After $\mathrm{r}, \mathrm{k}, \mathrm{x}$ and $\mathbf{~ \amalg , ~ ж , ~ ч , ~ щ ~ t h e ~ e n d i n g ~ ы и ̆ ~ i s ~ r e p l a c e d ~ b y ~ і и ̆ , ~ i n ~ a c c o r d a n c e ~}$ with 12 A 3 . But by analogy this in̆ is generally pronounced [ыj]. Very many Russians pronounce the ending ый (ій) without the diphthongal glide: [tolstы, šïrokы], instead of [-ыj].

\section{Possessive Pronouns:}

\begin{tabular}{|c|c|c|c|c|c|c|c|}
\hline person & мой & слова́рь & моя ' & тетра́дь & моё & перó & $m y$ \\
\hline & на шъ & & нá ma & & на́ ше & & our \\
\hline $\begin{array}{l}\text { person } \\
\text { person }\end{array}$ & $\begin{array}{l}\text { ва штъ } \\
\text { свой }\end{array}$ & 6 & $\begin{array}{c}\text { ва́ ша } \\
\text { своя́ }\end{array}$ & "6 & $\begin{array}{l}\text { ва́ ше } \\
\text { своё }\end{array}$ & " & $\begin{array}{l}\text { your } \\
\text { his, her, its. }\end{array}$ \\
\hline
\end{tabular}


1. Use the new adjectives in this text as predicates and as attributes with nouns of text $I$; see word-list, page 117, for accents.

2. Use the following adjectives as attributes with one suitable masculine, feminine, and neuter each: ма́ленькій small, большо́й big, дли́нный long, коро́ткій short, молодо́ї young, но́вый new, ста́рый old.

XIV

\section{ЧЕТЫРНАДЦАТЫЙ УРОКЪ}

\section{Вопро́сы}

1. Что э́то за зда́ніе? 2. Каково́ ва́ше у чи́лище-ма́ленькое и́ли большо́e? 3. Кто учи́тель? 4. Кто онъ? Кто она́? 5. Что я дъ'лаю? 6. Что вы дъ'лаете? 7. Какова́ э́та кни́га? 8. Лёгокъ ли б́тотъ слова́рь? (Нъ̆тъ, онъ...) 9. Тяжела́ ли вáша кни́га? 10. Кото́рая кни́га толста́, а кото́рая тонка́? 11. Какъ ва́ше и́мя? 12. Какъ ва́ша фами́лія?

\section{ПЯТНАДЦАТЫЙ УРОКЬ \\ TEXT III}

\section{Учитель и ученикъ}

Я учитель. Я говорю по-русски. Я не говорю по-англійски. Я говорю, а вы слушаете. Я спрашіваю по-русски, и вы отвъчаете порусски. Надо почти всегда говорить по-русскі.

Я не говорю скоро, я говорю медленно. Если вы не понимаете, вы должны спрашивать. Когда вы спрашиваете, вы говорите " $Я$ не понимаю, объясните мнъ это, пожалуйста." Тогда учитель даётъ объясненіе,и вы говорите "Благодарю васъ" или "Спасибо".

Этотъ урокъ не труденъ; онъ очень лёгокъ. Мы читаемъ кажғдый урокъ очень часто, но нам'ь не нужно переводить то что читаемъ. Теперь наше произношеніе плохо, но оно скоро будетъ хорошо. učitil i učinik

ja učitil. ja gavaru pa-ruski. ja ni gavaru pa-angliski. ja gavaru, a vы slušïits. ja sprašivaju pa-ruski, i vы atvičajitء pa-ruski. nada pačti fsirda gavarit' pa-ruski.

ja $n \mathbf{i}$ gavaru skora, ja gavaru medlino. jesli уы $n$ i panimajits, vы dalžnы sprašïvat $t^{6}$ karda уы sprašivajitє, vы gavaritє "ja $n$ i panimaju. apjısnit $\varepsilon m n \varepsilon \varepsilon t a$, pažalsta." tayda učitil dajot apjisnenije, і уы gavarite "blaradaru vas" $\mathbf{i} l \mathrm{i}$ "spasiba". stat urok $n \mathrm{i}$ trudin. on očin logak. mы čitajim každ̆jj urok očin casto, no nam ni nužna pirivadit $t^{r}$ to što čitajim. tiper naš $\varepsilon$ praiznašenij $\varepsilon$ ploxo, no ano skoro budit xarašo. 


\section{NOTES}

Всегда́: в before voiceless sounds = [f]; the suffix -гда is generally pronounced [rda]: когда, тогда.

Пожа́луйста: Contracted to [pažalsta] in pronunciation.

Practice:

[i] учи́тель, учени́къ, почти́, чнта́емъ, спаси́бо.

[e] э́ти, тепе́рь, пронзнопе́ніе, ме́дленно, е́сли.

[в] э́то, на́ше, текстъ, говори́те.

[a] на́до, всегда́, я, понима́ете, спра́шнвать.

[o] ско́ро, уро́къ, о́чень, что, даётъ.

[u] ' ру́сскій, слу́шаю, тру́денъ, говорю́, благодарю́.

[ы] вы, должнь́, ка́ждый.

[i] спра́шиваю.

NoтE.- - , being the typical palatal vowel, is always soft, b always hard.

\section{XVI \\ ШЕСТНАДЦАТЫЙ УРОКЂ}

25. Present Indicative.-Learn these paradigms; explanation will follow.

\begin{tabular}{|c|c|c|c|c|}
\hline & я & он'ъ, она́, оно́ & мы & вы \\
\hline $\left.\begin{array}{l}a .\{ \\
b . \\
c .\end{array}\right\}$ & $\begin{array}{l}\text { дъ'лаю } \\
\text { бу́ду } \\
\text { даю́ } \\
\text { говори́ }\end{array}$ & $\begin{array}{l}\text { дй'лаетъ } \\
\text { бу́детъ } \\
\text { даёть } \\
\text { говори́тъ }\end{array}$ & $\begin{array}{l}\text { дъ' лаемъ } \\
\text { бу́демъ } \\
\text { даёмъ } \\
\text { говориимъ }\end{array}$ & $\begin{array}{l}\text { ды'лаете } \\
\text { бу́дете } \\
\text { даёте } \\
\text { говори́те }\end{array}$ \\
\hline
\end{tabular}

Endings:

\begin{tabular}{l|l|l|l|}
\multicolumn{2}{c}{1 st } & \multicolumn{1}{c}{$2 \mathrm{~d}$} & \multicolumn{1}{c}{$3 \mathrm{~d}$} \\
\cline { 2 - 4 } $\begin{array}{l}\text { Sing. } \\
\text { Plur. }\end{array}$ & $\begin{array}{l}\text { уо } \\
\text { емъ, ёмъ, имъ }\end{array}$ & ете, ёте, ите & етъ, ётъ, итъ \\
\hline
\end{tabular}

\section{Imperative:}

дь' 'лайте, понима́йте, говори́те.

Write the same forms for the following verbs:

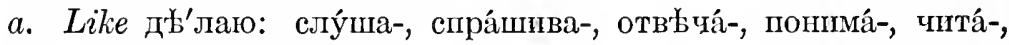
объясня́-, изуча́-, вызыва́-.

b. Like говори́: благодар-, уч- (the latter in -y, instead of -ю, according to $12 \mathrm{~A} 1$; the accent is on the ending in the 1st sing., on the stem in the other forms). 


\section{XVII}

\section{СЕМНАДЦАТЫЙ УРОКЪ}

\section{Вопро́сы}

1. Кто у́чить, п кто у́чится? 2. Что ды安'лаеть учи́тель? 3. Что ды'лаеть учени́ца? 4. Что вы хоти́те пвуча́ть? 5. Говори́тъ ли учи́тель по-а́нглійски? (Нъ̆ъ, онъ...) 6. Что вы

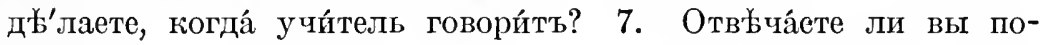
ру́сски? 8. Отв Ұча́ете ли вы по-а́нглійски? 9. Какъ на́до говори́ть почти́ всегда́? 10. Говори́ть ли учи́тель ско́ро? 11. Что вы должны́ ды́'лать, е́сли вы не понима́ете? 12. Что вы говори́те, когда́ вы не понима́ете? 13. Что дъ‘'лаеть учи́тель, когда́ вы спра́шиваете? 14. Что вы говори́те пото́мь? 15. Какъ э́тотъ уро́къ? Тру́денъ ли онъ и́ліг лёгокъ? 16. Что вы д'ъ'лаете, когда́ вы изуча́ете уро́къ? 17. Перево́дите лा вы ка́ждый уро́къ? 18. Хорошо́ ли тепе́рь ва́ше произноше́ніе ?

\section{XVIII}

\section{ВОСЕМЬНАДЦАТЫЙ УРОКЬ}

\section{TEXT IV}

\section{Ве щи въ школь}

Въ нашей комнат в кафедра, столъ, классная доска и. т. д. (и такь далґ̌е). На этомъ столь⿱⺊口灬 книга, карандашъ и перо. Въ столь' ящииъ, и въ этомъ ящикъ мълъ пг бумага.

У читель сидитъ на своёмъ большомъ кресль; я сижуу на маленькой скамейк歺 или на простомъ стуль. Учитель встаётъ пІ пдёть къ классной доскъ. Онъ держить въ рукъ мбль; онъ пишетъ на этой доскъ. У ченикъ пишетъ на бълой бумагъ или въ своей тетради. Когда мы пишемъ, наша бумага лежінт на нашемъ столь. vešči f školı

v našej komnat $\varepsilon$ kafidra, stol, klasnaja daska i tak dalijs. na etam stale kniga, karandaš i piro. f stalı jaščik, i v etam jaščiks $m \boldsymbol{\varepsilon}$ i bumaga.

učitil sidit na svajom balšom kresls; ja sižu na malinkoj skamejk $\varepsilon \mathbf{i} l i$ na prastom stul $\varepsilon$. učitil fstajot $\mathrm{i}$ idot $\mathrm{k}$ klasnoj

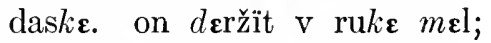
on pišit na etoj daske. - učinik pišit na beloj bumag $\varepsilon$ i $l i$ f svajej titradi. $\quad k a \gamma d a$ mï pišïm, naša bumaga ližit na našim stale. 
Столь стоить на полу. Въ одномъ углу стоитъ шкапъ, и въ этомъ шкапу лежитъ бумага, перо и карандашъ. Бумага принадлежить ученику, а карандашъ принадлежить учителю. Учитель даёть карандашъ этому ученику; онъ даётъ перо этої ученицъ.

Когда мы приходимъ къ нашему учителю или къ другу, мы говоримъ "Здравствуйте", и когда мы уходимъ, мы говоримъ "До свиданія" или "Прощайте". stol stait na palu. $\mathrm{v}$ adnom uglu stait škap, i v etam škapu ližit bumaga, piro i karandaš. bumaga prinadližït učiniku, a karandaš prinadližit učitilu. Učitil dajot karandaš etamu učiniku; on dajot piro etoj učinitse.

kayda mы prixodim $\mathrm{k}$ našĭmu učitilu ili g drugu, mы gavarim "zdrastvujte", i karda mы uxodim,mы gavarim "da svidanija" ili "praščajte".

\section{NOTES}

Въ своёмъ, встаёте, къ дру́гу: Assimilation (11, 1 a, d).

Стойтъ: Remember that if is pronounced with [j]-glide only in the words ихъ, имъ, и́міг.

Здра́вствуйте: In the group вств, the first в is generally silent.

Practice:

$$
\begin{aligned}
& \text { б-[b] бума́га, [b] бъ' лый, [p] грубъ. } \\
& \text { г-[g] кни́га, }[\gamma] \text { когда́, }[\mathrm{k}] \text { могъ, }[\mathrm{x}] \text { легко́. } \\
& \text { д-[d] доска́, }[d] \text { спди́ть, [t] надъ, [t] тетра́дь. } \\
& \text { в--[v] въ на́шей, [f] въ свое́й. } \\
& \text { 3-[z] здра́вствуйте, [s] изъ. } \\
& \text { п- }[\mathrm{p}] \text { поль, }[p] \text { пять. } \\
& \text { к-[k] каранда́шъ, [x] кто. } \\
& \text { T- }[\mathrm{t}] \text { э́то, }[t] \text { учи́тель. }
\end{aligned}
$$

ACCent.-Constant, careful observation and practice are the only safe way of learning the Russian accent. Read the right-hand column over and over again covering the phonetic text with a strip of paper, until you place all accents correctly without hesitation.

\section{XIX}

\section{ДЕВЯТНАДЦАТЫЙ УРОКЂ}

27. The Locative Case indicates the place where something is; it is always used in connection with certain prepositions and is therefore also called the Prepositional Case. 
Masc.

въ (на) столњ'
въ кла́ссł
въ я́щикł́
на полу́
въ углý

$$
\text { Neut. }
$$

NOUNS

на кре́сль

въ учйлищ'

на по́ль

въ зда́ніи

объ ймени
Fem.

въ шко́ль

на скаме́йкъ

въ рукњ́

о фами́ліи

въ тетра́ди

\section{PRONOUNS AND ADJECTIVES}

на э́томъ...
въ на́шей...
въ своёмъ...
въ кла́ссномъ...
в’ большо́мъ... на э́той.

въ на́шей...

въ свое́й...

на бъ'лой...

на большой...

Endings:

Nouns

Pronouns and Adjectives

\begin{tabular}{|l|l|}
\multicolumn{1}{c}{ M.N. } & F. \\
\hline $\begin{array}{l}\text { †-и, ý } \\
\text { омъ-емъ }\end{array}$ & $\begin{array}{l}\text { Ћ-и } \\
\text { ой-ей }\end{array}$ \\
\hline
\end{tabular}

The following take и:

a. Feminines in ь and neuters in мя (тетра́ди, и́мени).

b. Feminines in ія and neuters in ie, according to 13 В (фами́ліи, зда́ніи).

The ending $\hat{\mathbf{y}}$, always accented, occurs with a number of masculines after the prepositions въ and на (въ углу́, на берегу́ on the shore).

28. The Dative is the case of the indirect object; it is also required by certain prepositions.

$$
\text { Masc. }
$$

Neut.

Fem.

\begin{tabular}{|c|c|c|c|}
\hline$\underset{\text { Hard: }}{\text { Hard }}$ & $\begin{array}{l}\text { ученики́ } \\
\text { дру́гу }\end{array}$ & $\begin{array}{l}\text { кре́слу } \\
\text { учи́лищу }\end{array}$ & 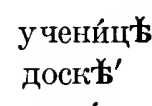 \\
\hline Soft: & учи́телю & по́лю & \\
\hline
\end{tabular}

\section{NOUNS}

\section{PRONOUNS AND ADJECTIVES}

ә́тому

на́шему, своему́

широ́кому э́той

на́шей, свое́й

широ́кой 
Endings:

Nouns
Pronouns, Adjectives

\begin{tabular}{|l|l|}
\multicolumn{1}{r|}{ M.N. } & \multicolumn{1}{c}{ F. } \\
\hline $\begin{array}{l}\text { y-ю } \\
\text { омy-емy }\end{array}$ & $=$ Loc. \\
\hline
\end{tabular}

Form the locative and dative singular of all nouns in texts $I$ and $I I$, adding a suitable adjective or pronoun to each noun (e.g., къ на́шемy столу́, на на́шему стол‘́’').

$\mathrm{XX}$

\section{ДВАДЦАТЫЙ УРОКЬ}

\section{Вопро́сы}

1. Гд⿱⺊口 вы тепе́рь? 2. Что есть въ ва́шей кла́ссной ко́мна-

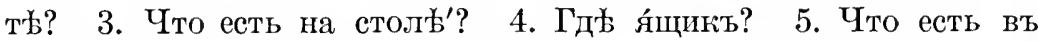

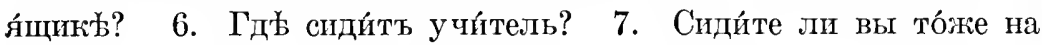
кре́сль⿱宀 8. Куда́ идёть учи́тель? 9. Что онъ де́ржить въ

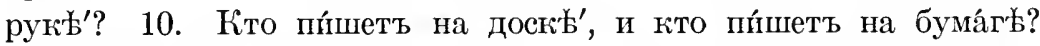

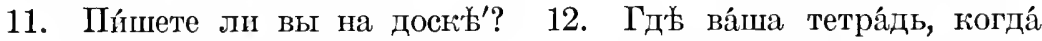
вы пи́шете? 13. Гдъ стои́тъ столъ? 14. Что стои́тъ въ углу́? 15. Что лежи́ть въ шіапу́? 16. Кому́ прннадлежи́́ть бума́га в’ь шкапу́? 17. Комý прпнадлежи́́ть перо́? Кому́ каранда́шъ? 18. Кому́ даётъ учи́тель каранда́шъ и перо́? 19. Что вы говори́те, когда́ вы прихо́дите къ ва́шему дру́гу? 20. Когда́ вы говори́те "До свида́нія"?

\section{XXI}

\section{ДВАДЦАТЬ ПЕРВЫЙ УРОКЬ}

\section{TEXT V \\ Писаніе

$$
\text { pisan } \ddot{i j} \varepsilon
$$

Въ началь урока учитель вызываеть къ классной доскь у ченика или ученицу. Учитель стопть возл'ъ окна. Онъ открываетъ свою́ книгу и читаетъ вслухъ вопросъ. У ченик' пишетъ отв'ьть. Когда онъ дйлаетъ ошибку, учитель поправляеть её. Потомъ учитель опять закрываетъ книгу и объясняетъ новый урокъ безъ інпигі. v načal jit učinika ili učinitsu k klasnoj daske. učitil stait vozl akna. on atkrovajit svaju knigu i fslux čitajit vapros. učinik pišit at-

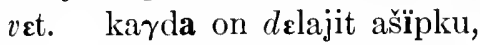
učitil papravlajit jijo.

patom učitil apat' zakrırvajit knigu i apjısnajit novыj urok $b \varepsilon s \mathrm{k} n \mathbf{i} g \mathrm{i}$. 
У учителя русскій учебникъ и русскій словарь; у ученика учебникъ, тетрадь и перо. Мы пишемъ въ тетради перомъ, а на бумагъ часто пишемъ карандашомъ вмйсто пера; на доск' пишемъ ме́лломъ. Когда мы пишемъ урокъ, мы вынимаемъ изъ ящика тетрадь или бумагу и кладёмъ её на столъ. Пишемъ правой рукой и держимъ бумáry лŁ́вой рукой. $\mathrm{У}$ меня́ въ карманґ ножикъ; когда мой карандашъ тупъ, я вынимаю ножикъ изъ кармана пा чнню карандашт ножиком'b.

u učitila ruskbj učebnik i ruskij slavar; u učinika učeb$n i k, t i t r a t^{6}$ i piro. mo pišïm f titradi pirom, a na buma $g \varepsilon$ často pišïm karandašom $v m \varepsilon$ sto pira; na daske pišïm melam. karda mы pišïm urok, mы vыnimajim iz jaščika titrat $t^{6}$ ili bumagu i kladom jijo na stol. pišǐm pravoj rukoj i deržïm bumagu levoj rukoj. u mina f karman $\varepsilon$ nožik; karda moj karandaš tup, ja vыnimaju nožik is karmana i činu karandaš nožikam.

\section{NOTES}

Prepositions.- - Bъ, нa require the locative when rest is denoted, but the accusative when motion is denoted: Каранда́шъ на стол'ъ', въ карма́нъ._Кладу́ каранда́пъ на столъ, въ карма́нъ.

Къ requires the dative: Ученйкъ идётъ къ клта́ссной доскъ'.

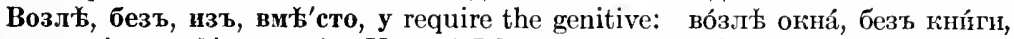
нзъ карма́на, вмь'сто пера́.-У мени́ I have, у у чи́ттеля the teacher has.

Practice:

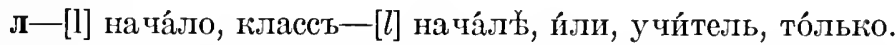

p- $[\mathrm{r}]$ ру́сскії, закрыва́етъ, карма́нъ- $r]$ царь, Ха́рьковъ.

н-[n] на, нача́ло, карма́нъ, каранда́шъ-[n] ни, кни́га, у чени́къ, у че́бникъ.

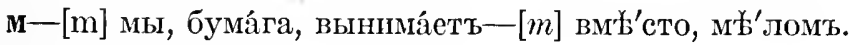

\section{XXII}

\section{ДВАДЦАТЬ ВТОРОЙ УРОКЬ}

29. The Genitive corresponds to the English possessive and is also required by certain prepositions.

Masc.

Hard: въ начáль́ урóka

“ изъ карма́на

Soft: у учи́теля

" у геро́я
Neut.

вм'ъ́'сто пера́ во́зл瓷 окна́ зда́нія и́мени
Fem. изъ шко́лы у учени́цы фами́ліи тетра́ди 
Endings:

Neuters in мя take и: и́мени.
M.N. F.

Hard

\begin{tabular}{|l|l|}
\hline $\mathbf{a}$ & $\mathbf{b I}$ \\
$\mathbf{g}$ & $\mathbf{n}$ \\
\hline
\end{tabular}

\section{Vowel Variation:}

Nom. доска́, кни́га, рубáxa (shirt), да́ча (villa), кóжа (skin), кáша (porridge). Gen. доски́, кни́ги, руба́хи, да́чи, кб́ঞи, ка́ши.

After all velars $(\kappa, r, x)$ and after the sibilants ч, щ, ш, ж (but not after ц) ы is replaced by и. Compare $12 \mathrm{~A} 3$.

31. The Accusative is the case of the direct object; it is also required by certain prepositions.

\section{Things}

Persons

М. Учйтель открыва́еть слова́рь.

Учи́тель чита́етъ вопро́съ.

F. У чи́тель открыва́етъ кни́гу.

Учи́тель открыва́етъ тетра́дь.

Онъ вызыва́етъ ученика́.

Онъ вызыва́етъ учени́цу.

N. Учи́тель открыва́етъ окно́.

Endings:

Things:

Animate Beings:
M.

\begin{tabular}{|l|l|l|}
\hline $\begin{array}{l}=\text { Nom. } \\
=\text { Gen. }\end{array}$ & $=$ Nom. & $\mathbf{y}$-ю (ь)* \\
\hline
\end{tabular}

* Feminines in $\mathbf{b}$ have the accusative like the nominative.

32. The Instrumental denotes the means by which something is done; it is also required by certain prepositions.

M. карандашо́мъ у чи́телемъ царёмъ

Endings:

$\mathrm{N}$.

перо́мъ

зда́ніемъ и́менемъ
F. руко́й (-о́ю) фами́ліей (ею) тетра́дью

\begin{tabular}{l|l|l|}
\multicolumn{1}{c}{ M.N. } & \multicolumn{1}{c}{ F. } \\
\cline { 2 - 3 } $\begin{array}{l}\text { Hard } \\
\text { Soft }\end{array}$ & $\begin{array}{l}\text { омъ } \\
\text { емъ (ёмъ) }\end{array}$ & $\begin{array}{l}\text { ой (ою) } \\
\text { ей (ею), ью }\end{array}$ \\
\cline { 2 - 3 }
\end{tabular}

Feminine: The abbreviated ending ой, eй is much more frequent than the full ending ою, ею. Feminines in $\mathbf{s}$ take $\mathbf{b}$. 


\section{Vowel Variation:}

After the sibilants ц, $\amalg$, ж, ч, щ, $о$ in unaccented endings is replaced by e (12 A 4): оте́цъ father, каранда́шъ: отцб́мъ, карандашо́мъ.

мужъ man, нашъ: му́жемъ, на́шемъ.

кни́га-кни́гой, but учени́ца-у чени́цей.

This explains the forms на́шем'ъ, на́шей, на́шему in 27 and 28.

Form the genitive, accusative ( = nom. or gen., according to meaning), and instrumental of all nouns in Texts $I I I, I V, V$.

\section{XXIII}

\section{ДВАДЦАТЬ ТРЕТІЙ УРОКЬ}

\section{Boпрócы}

1. Какъ загла́віе э́того текста? 2. Что учи́тель д'̌́'лаетъ въ нача́ль́ уро́ка? 3. Гдъ онъ стои́тъ? 4. Кто открыва́етъ кни́гу? 5. Что учи́тель дъ'лаетъ? 6. Кто пи́шетъ отвъ'тъ на вопро́съ учи́теля? 7. Что пото́мъ дъ'лаетъ учи́тель? 8. У кого́ ру́сскій уче́бникъ? 9. Что есть у ученика́? (У него́ ..) 10. Есть ли у учени́цы уче́бникъ? (Да, у нея́..) 11. Чбмъ вы пи́шете въ тетра́ди? 12. Пи́шете ли вы на бума́гъ́ перо́мъ? 13. Что вы д’’'лаете когда́ вы хоти́те писа́ть? 14. Куда́ вы кладёте бума́гу? 15. Что вы дъ‘'лаете ль'b'вой руко́й, когда́ вы

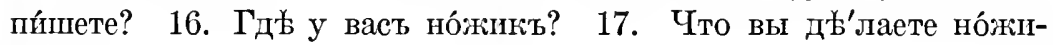
комъ?

\section{XXIV}

\section{ДВАДЦАТЬ ЧЕТВЕРТЫЙ УРОКЬ}

\section{REVIEW}

\section{Noun Paradigms}

M.

N. столъ

А. столь

G. стола́

L. стол'安

D. столи́

I. столо́мъ учи́телемъ
$\mathrm{N}$.

онко́

окHо́

окна́

OKH ${ }^{\prime}$

окни́
F.

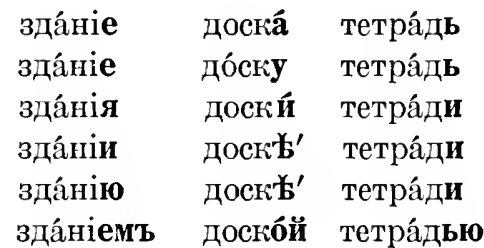


1. Write the singular paradigms of the following nouns: перо́, стулъ, зда́ніе, каранда́шъ, столъ, и́мя, потоло́къ (gs. потолка́; о in the last syllable is omitted in all oblique cases), па́лка, кни́га, доска́, шко́ла, учени́ца, окно́, тетра́дь.

2. Add a suitable adjective to the nominative, locative, and dative of each of these nouns; substitute a possessive or demonstrative pronoun for each adjective.

3. Use the following noun and verb forms in sentences: кни́гу, перо́мъ, чита́етъ, шкапъ, шкапу́, держу́, учи́телю, говорю́, мъోлъ,

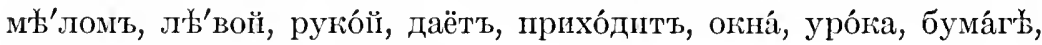
но́жикъ, тетра́ди, открыва́емъ.

\section{$\mathrm{XXV}$ \\ ДВАДцАТЬ ПЯТЫЙ УРОКЂ}

TEXT VI

\section{Утро}

Я обыкновенно встаю в'ь шесть часовъ утра. Иду въ ванную и купаюсь или моюсь холодной водой льътомъ, а тёплой водой зимою. Чищу зубы зубной щёточкой. Пью стакан'ь чистої холодной воды. Брқюсь безопасной бритвой іи причёсываю волосы большимъ гребнемъ и головной цёткой. Между тьиъ я стою передъ круглымъ зеркаломъ, которое висптъ на стььљљ ванной.

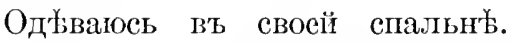
Одњваго чистую рубаху и чиетый воротникт каждое утро. Вт общемъ туалетъ у меня продолжается полчаса. Посль туалета я захожу въ столовую п сажусь за столъ. Если завтраґъ ецё не готовъ, я читаю утреннюю газету. utro

ja abïknavena fstaju $\mathrm{f}$ šest črsof utra. idu v vannuju i kupajus ili mojus xalodnoj vadoj lztam, a toploj vadoj zimoju. čišču zubы zubnoj ščotačkoj. $p^{6} \mathbf{u}$ stakan čistoj xalodnoj vadы. brejus bizapasnoj britvoj i pričsыvaju volast balšïm greb-

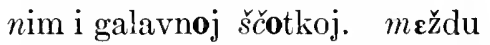
$t \varepsilon m$ ja staju pirit kruglbm $z \varepsilon r-$ kalam, katoraje visit na stine vannoj.

adivajus f svajej spaln $\varepsilon$. adivaju čistuju rubaxu i čisttj varatnik každaje utro. v opšcim tualet u mina pradalžajitsa palčrsa. posle tualıta ja zaxažu f stalovuju i sažus za stol. jesli zaftrak jiščo $n$ i gatof, ja čitaju utrinnuju gazetu. 
За завтракомъ я обыкновенно пью чашку тёплаго молока или стаканъ горя чаго чаю и ьмъ два яйца и кусокъ хльбба съ масломъ. Я всегда пью свой чай безъ сахару; не люблю сладкаго чато. za zaftrakam ja abыknavenna $p^{6} \mathbf{u}$ čašku toplava čaju ili stakan garačrva malaka i jem dva jitsa i kusok xleba s maslam. ja fsi $\gamma d \mathbf{a} p^{\prime}$ u svoj čaj bis saxaru; ni lublu slatkava čaju.

\section{NOTES}

Въ шесть часо́въ утра́ At six o'clock in the morning.

нн (ва́нная, обыкнове́нно) is generally pronounced as a lengthened consonant (similar to final $n$ in man, can).

Л术'томъ, зимо́ю: Instrumental of time (весно́й in spring, бсеныо in fall).

Пью: $\mathbf{b}$ between consonant and vowel is pronounced as a distinct [j]-glide, half-voiceless after a voiceless consonant: $\left[p^{\prime} \mathbf{u}\right]$.

Не люблю́ сла́дкаго ча́ю: (1) Чáю, cáxapy, irrregular genitives, see \ 14, 4. (2) With negative verbs the direct object stands in the genitive instead of the accusative; I $22,2 b$.

\section{Practice:}

1. The Sibilants: шесть, больши́мъ, ча́шка, ме́жду, ка́ждый, захожу́, сажу́сь, часо́въ, причёсываю, полчаса́, горя́ чій, чай, чи́щу, щёточка, общемъ, ещё.

2. ё: щётка, щёточка, причёсываю, ещё.

e is generally pronounced [jo] when it is accented and followed by a syllable with a hard vowel. Final accented $\mathbf{e}$ is always [jo, o] with the exception of the words yжié 'already' and вообще́ 'in general'

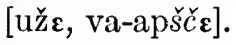

Noте.-ъ counts as a hard vowel: идёть, кладёть. Exceptions from the rule are chiefly the nouns in -ецт: купе́цъ merchant $=$ [kupets]. There are also a few isolated cases, such as безъ without [bøs] (unaccented [bis]), четве́ргъ Thursday [čitverk], пе́рвый first [pєrvыj] or [pervыj], and a few others.

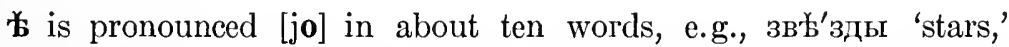

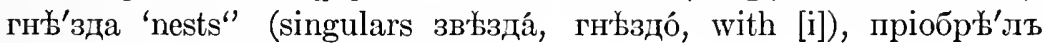
'he received', цвъ' 'ль 'blossomed'.

я has the sound [jo] in eя́, gs. of oнá 'she,' трясъ 'shook,' запря́г 'yoked'. 


\section{XXVI}

\section{ДВАДЦАТЬ ІІЕСТОЙ УРОКЬ}

\section{Declension of Adjectives:}

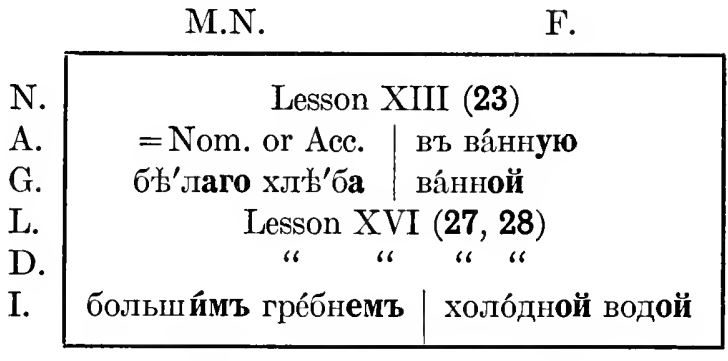

\begin{tabular}{|c|c|c|c|c|c|c|}
\hline & \multicolumn{3}{|c|}{ HARD } & \multicolumn{3}{|c|}{ SOFT } \\
\hline & M. & N. & F. & M. & N. & F. \\
\hline N. & ый, ой & oe & ая & ій & ee & яя \\
\hline A. & N. or G. & oe & ую & N. or G. & ee & юю \\
\hline G. & aro, or & & & яго & & \\
\hline L. & омъ & & ой & емъ & & ей \\
\hline D. & омy & & & емy & & \\
\hline I. & Ымт & & & имъ & & \\
\hline
\end{tabular}

\section{REMARKS}

1. The accent remains on the same syllable in all cases: ширб́кій, ширб́каго, большбй, больпбго.

2. Adjectives with accented endings have öй instead of ый in the nom. sing. masc. and oro instead of аго in the gen. sing. masc. and neut.: большбй, больmóro. Their dative ends in óму: болыпбму.

3. No soft adjective has the accent on the ending (unless the possessive pronouns мой, твой, свой are considered as adjectives; ๆ 18).

4. The ending aro, oro of the gen. sing. masc. and neut. is pronounced [ava, ova].

5. As with nouns, the instr. fem. has also a longer, less common, form in -ою, -ею.

6. The rules of vowel variation must be observed. Compare $12 \mathrm{~A}$ for the following forms: Ширбкій, широ́кпмъ, хорб́шій, хорбшая, хорб́шемъ, больши́мъ, болша́я, but большо́й, большо́му.

7. The use of adjectives as nouns is very common; their declension is the same as when used attributively: гости́ная guestroom, столбвая dining-room, ва́нная bathroom-sc. кб́мната. Most Russian family names are substantivized adjectives, е.g., Толстбй-Толстб́г, Достое́вскій-Достое́вскаго, Ке́ренскійКе́ренскаго. 
1. Decline the singular of: ва́нная, столо́вая, чи́стая вода́, кру́глое зе́ркало, холо́дное молоко́, чи́стый стака́нъ, горя́чій чай, бъ'лый хльббъ.

2. Add a suitable adjective to every noun in Texts $I V$ and $V$; in addition to the adjectives that have occurred, the ordinals пе́рвый ' $f$ irst',' второ́ї 'second' (declined like regular adjectives), may be used, e.g., въ пе́рвомъ нача́ль⿱一𫝀, второ́го уро́ка.

\section{XXVII \\ ДВАДЦАТЬ СЕДЬМОЙ УРОКЬ}

35. Declension of Pronouns.-The endings of the attributive adjectives have been borrowed from the pronominal declension, i.e., from the declension of words like э́тотъ, мой. The term 'pronominal adjectives' should not be used in Russian grammar; it is better to speak of 'demonstrative pronouns', 'possessive pronouns', etc.

The following pronouns have occurred:

1. Personal: я, мы, вы, онъ, она́.

2. Possessive: мой, на шъ, ва шъ, свой.

3. Demonstrative: כ́тоть.

4. Interrogative-relative: кто, что, кото́рый.

The declension of the personal pronouns is irregular. That of some of the other pronouns differs from the adjective declension in the nominative forms, which are like those of nouns (мой like герб́й, нашъ like каранда́шъ), and in regard to the accent.

36. Reflexives.-Reflexive verbs are exceedingly numerous in Russian. They are formed by adding the reflexive suffix -ся, -сь to the verb; -cя (pronounced [sa], not [sa]) is, in general, used after consonants, -сь after vowels; $\mathbf{b}$ is omitted before -ся:
я одъвва́юcь
мы одъва́емся
вы од'ъва́етесь
он'ъ од'ъва́ется.

Notice that the suffix (aside from the purely phonetic variation -сь--ся) is the same for all persons. In the same way, the reflexive possessive pronoun свой is used for all three persons:

Я чита́ю свою́ кни́гу I read my book.

Онъ чита́етъ свою́ кни́гу he reads his book.

Она́ чита́етъ свою́ кни́гу she reads her book.

Мы чита́емъ свою́ кни́гу we read our book (books).

Вы чита́ете своб кни́гу you read your book (books). 
1. Decline the singular of: э́тотъ гре́бень, на́ше зе́ркало, свой стака́нъ, кото́рый кру́глый столъ, моё тёплое молоко́.

2. Collect all forms of personal and demonstrative pronouns that have occurred in the texts and questions and form three sentences with each.

3. Conjugate (in the three forms given above) and add the correct endings for the blanks: Я одъ̌ва́юсь въ э́т- ко́мнат-; я купа́юсь въ сво一 ва́нн一, брł'юсь пе́редь сво一 зе́ркал一, я кладу́ бума́гна сво-стол一.

\section{XXVIII \\ ДВАДЦАТЬ ВОСЬМОЙ УРОКЬ}

\section{Вопро́сы}

1. Когда́ вы обыкнове́нно встаёте? 2. Куда́ вы сперва́ идёте? 3. Что вы д’ъ’лаете въ ва́нной? 4. Мо́етесь ли вы всегда́ холо́д-

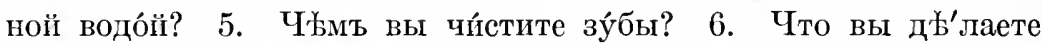
пото́мъ? 7. Како́й бри́твой брб’етесь? 8. ЧЪъмъ вы причёсываете во́лосы? 9. Гд⿱丷⿹ вы стои́те, когда́ вы причёсываете

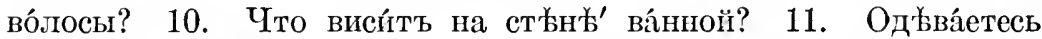
ли вьї въ свое́ї ва́нной? 12. Ско́лько вре́мени продолжа́ется

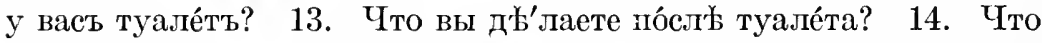
вы пьёте за за́втракомъ? 15. Чнта́ете ли вы газе́ту всегда́ пе́редъ за́втракомъ? 16. Что вы ку́шаете за за́втракомъ? 17. Пьёте ли вы свой чай съ са́харомъ? 18. Почему́ вы пьёте свой чай безъ cáxapy?

\section{XXIX \\ ДВАДЦАТЬ ДЕВЯТЫЙ УРОКЬ \\ TEXT VII \\ Домъ \\ dom}

Домъ состонтъ изъ ст тнъ, половъ, потолковъ и крыши. Въ большихъ городахъ есть много домовъ въ три или тетыре этажа. Наша квартира находитея на второмъ этажь большого дома. Въ ней сльдующія комнаты: гостиная или пріёмная, столовая, кухня и три спальни. dom sastait is sten, palof, patalkof i krыšĩ. $\quad \mathrm{v}$ balšĩx garodax jest' mnoga damof f tri ili čitbre staža. naša kvartira naxoditsa na ftarom etaže balšova doma. v $n$ ej sledujuščij k komnatb: gastinaja ili prijomnaja, stolovaja, kuxna i tri spalni. 
Въ гостиной принимаютъ гостей. Поль ея устланъ коврами, и на стьнахъ висятъ прекрасныя картіны. Спальни-комнаты, въ которыхъ спятъ люди; въ спальняхъ стоятъ гровати, комодын высокіе шкапы. Въ кухн各 приготовляють кушанье; съђстные припасы хранятся въ кладовыхъ нли въ погребахъ.

Столовая-комната, въ которої кушаемъ: завтракаемъ, объдаемъ и ужинаемъ. Въ столовой стоятъ большой, круглый столь н высокій буфетъ. Около стола стоить нъсголыко стульевъ. Столь покрыть чистой, бълой скатертью; на столь стоятъ тарелгки, чашки, стаканы, и лежать ножи, вилки, ложки, ложечки и салфетки. Мы фдимъ супъ ложками, мясо вилками и ножками. Пьёмъ чай изъ стаканов'ь, но кофе изъ чаптекъ.

За нашимъ домомъ находитея прекрасный садъ. Въ саду высокія деревья. Посльь объда я часто гуляг полчаса по тьнистымъ алле́ямъ нашего сада. $\mathrm{v}$ gastinoj prinimajut gastej. pol jijo uslan kavrami, i na stinax visat prikrasnuj $\varepsilon$ kartinы. spalni-komnats, f katorыx spat ludi; f spalnix stajat kravati, kamodo i visokijs škapы. f kuxnє prigatavlajut

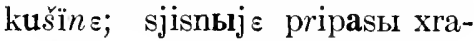
natsa f kladavox ili f pagribax.

stalovaja-komnata, f katoroj kušijim: zaftrakajim, abedajim i užinajim. f stalovoj stajat balšoj, kruglыj stol i vыsokыj byfet. okala stala stait $n \varepsilon-$ skalka stul'if. stol pakrыt čistoj, beloj skatirt'u; na stale stajat tarعlki, čaški, stakanы, i ližat nažï, vilki, loški, ložïčki i salfetki. mы jidim sup loškami, maso vilkami i nažami; $p^{\prime}$ om čaj is stakanaf, no kof $\varepsilon$ iš čašǐk.

za našïm domam naxoditsa prikrasnыj sat. fsadu vыsoki-

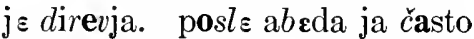
gulaju polčrsa pa tinistbm alejım našiva sada.

\section{NOTES.}

Дома́: Irregular plural of домъ; notice the accent; домма is the gen. sing.

Въ три этажа́ of three stories; the form этажа́ will be explained in Lesson 34.

Въ ней: Locative of она́, instead of eй, after prepositions.

Принима́ютъ they receive guests, i.e., guests are received; приготовла́ютъ ку́шанье food is prepared.

Устлӓнъ: т between $\mathrm{c}$ and л is silent.

Таре́лки: Sеe 21, 3 for pronunciation.

Нъъ'сколько сту́ левъ: Нъ'сколько (and similar expressions of indefinite number or quantity) is followed by the gen. plur. Стуллевъ is an irregular form; the nom. plur. is сту́лья; similarly де́рево tree, plur. дере́вья, gen.-ьевъ.

Потоло́къ-потолко́въ: Vowel insertion according to $12 \mathrm{C}$. Compare 23 A, b and below, 37, Remark 3. 
Practice:

[ji, i] ихъ, изъ, состои́тъ, нахо́дится, кварти́ра, э́ти.

[je, е] ней, госте́й, салфе́тки, есть, семь.

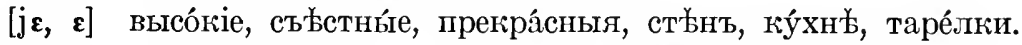

[ja, a] стоя́тъ, бъ'лая, столо́вая, спятъ, вися́тъ, мя́со, чи́стая.

[jo, o] ея́, пріёмная, ковёръ, пьётъ, кладёмъ.

[ju, u] гуля́ю, приготовля́ю, принима́ютъ, лю́ди.

ь: спа́льня, ку́шанье = ку́шаніе, большо́й, нъ̌́cколько, пьёмъ, ска́терть, дере́вья.

\section{XXX \\ ТРИДцАТЫЙ УРОКЬ}

37. Plural of Nouns:

M.

N. шкапи́

ножіи

лю́ди

G. поло́въ

госте́й

L. погреба́х гост я́xъ

D. ' пाкапа́мъ Гост Я́мъ

I. ковра́ми гост भ́ми
N.

слова́

о́кна

дере́вья

слов'

дере́вьевъ

слова́хъ

дере́вьяхъ

слова́мъ

дере́вьямъ

слова́ми

дере́вьями
F.

ко́мнаты

ло́жки

спа́льни

стьॅнъ

спа́ленъ

ко́мнатахъ

спа́льняхъ

коммнатамъ

спа́льнямъ

ко́мнатами

спа́льнями.

Endings:

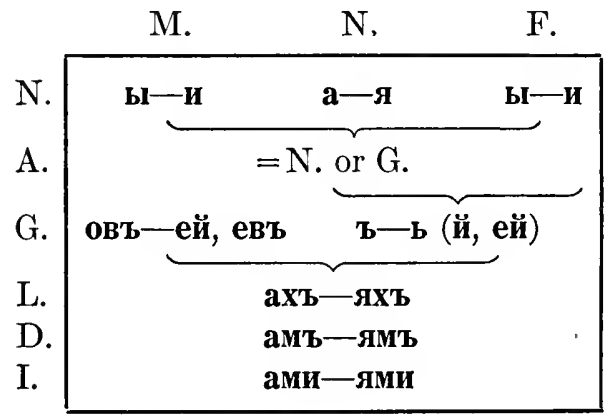




\section{REMARKS}

1. The rules of vowel variation must be observed, e.g., потоло́къ-потолки́

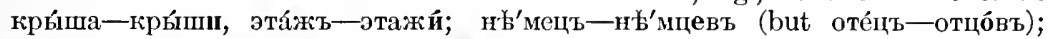
фами́лія-фами́ліӥ (instead of фами́ліь).

2. GENITIVE PLURAL. In general outlines, the distribution of the various endings is the following:

ов'ъ with hard masculines: домъ-домо́въ.

евъ with masculines in й: геро́й-геро́евъ; also with those in цъ, if the ending is unaccented (12 A 4): н安'мецъ-н安'мцевъ, but оте́цъ一отцо́въ.

eü with all nouns in $\mathbf{b}$, with masculines in шъ, жъ, чъ, щц, and with neuters . in e (not in ie); тетра́дей, ноже́й, по́лс́й (по́ле field).

ъ with all hard feminines and neuters: ко́мнатъ, жёнъ, словъ, бконъ; also with a few feminines in я that insert e between final consonants: спа́льня-спа́лент

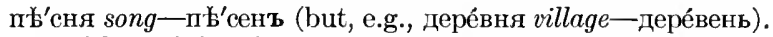

b with feminines in $я$ after consonants: ня́ня-нянь.

й with feminines in iя and neuters in іе: фами́лій, зда́ній.

3. Vowel Insertion is required when the gen. plur. ends in $\mathrm{b}$ or $\mathrm{b}$ after two consonants that would be inconvenient to pronounce as"a group: окнб-бконъ, ло́жка ло́жекъ; compare $12 \mathrm{C}$ and $23 \mathrm{~A}$, b.-Nouns like судьб́́ destiny, спи́льня omit their $\mathrm{b}$ in such forms; for it is nothing but a sign that the preceding consonant is soft, and this fact is sufficiently indicated by the palatal vowel е: су́дебъ, спа́лен'ъ.

4. The Accusative Plural of all three genders has the form of the nominative in the case of things, but the form of the genitive in the case of animate beings: Я вижу ( $I$ see) столь́, ко́мнаты, зда́нія-волко́въ, лошаде́й, дбттей (волкъ wolf, ло́шадь horse, дитя́ child-irregular gen. plur.).

38. Plural of Verbs (3d person).

\begin{tabular}{|c|c|c|}
\hline Infinitive & $3 d$ Singular & $3 d$ Plural \\
\hline $\begin{array}{l}\text { ды́'лать } \\
\text { принима́ть } \\
\text { висб'ть } \\
\text { храни́ть } \\
\text { лежа́ть }\end{array}$ & $\begin{array}{l}\text { д安'лаеть } \\
\text { прннима́еть } \\
\text { виси́ть } \\
\text { хранйть } \\
\text { лежи́ть }\end{array}$ & 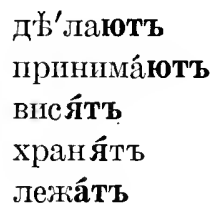 \\
\hline
\end{tabular}

1. Change all singular nouns and verbs in this text to the plural of the same case or person, e.g., домъ-дома́, состои́тъ-состоя́тъ, кри́шшкрышъ.

2. In the same way, change the plural forms of all nouns and verbs in the text to the singular, e.g., стьнт-стьны, принима́ють-принима́етъ.

3. Change all verbs in text III to the third person plural and all nouns in text $V$ to the plural of the same case, e.g., я говорю-они́ говоря́тъ, въ нача́ль́-въ нача́лтахъ. 
XXXI

ТРИДЦАТЬ ПЕРВЫЙ УРОКЪ

39. Plural of Adjectives:

Attributive:

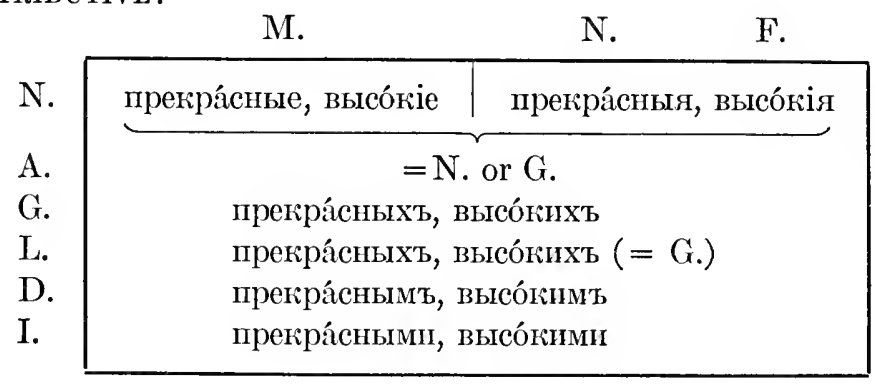

Endings:

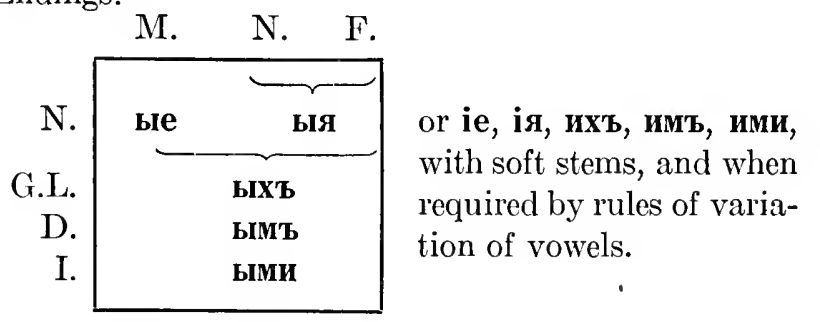

The rule for the accusative is the same as with nouns $(37,4)$.

Predicative:

The ending is $\mathbf{b}-\mathbf{n}$ for all genders: дома́ (ко́мната, дере́вья) прекра́сны (высо́ки).

40. Plural of Pronouns. - With the exception of a few nominative forms, the plural of 'pronominal adjectives' (35) is exactly like that of common adjectives. The connecting vowel is $\mathbf{n}$ with demonstratives, possessives, and some others (46).

\section{Plural of all three Genders}

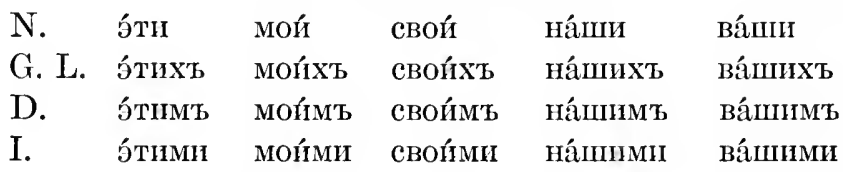

Кото́рый is declined as a common adjective: кото́рые, кото́рыхъ. 
1. Add a suitable adjective to every noun plural formed in accordance with Lesson $X X X$, Exercise 3.

2. Change the possessive and demonstrative pronouns in Texts II and $I V$, together with their nouns, to the plural of the same case, e.g., э́то болыпое зда́ніе-бтти болыші'я зда́нія.

3. Decline in the singular and plural: мой но́вый домъ, э́тоть чёрный каранда́шъ, ва́ша прекра́сная гости́ная, э́то высо́кое окно́.

\section{XXXII \\ ТРИДЦАТЬ ВТОРОЙ УРОКЂ}

\section{Вопросы}

1. Изъ чего́ домъ состои́тъ? 2. Ско́лько этажке́й въ ва́шемъ до́мъ? 3. На кото́ромъ этажъ‘ ' нахо́дится ва́ша кварти́ра? 4. Какі'я ко́мнаты въ ва́шей кварти́рł? 5. Что дъ'лаютъ въ гости́-

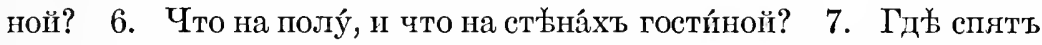
лю́ди? 8. Что въ спа́льняхъ? 9. Для чего́ слу́жить ку́хня?

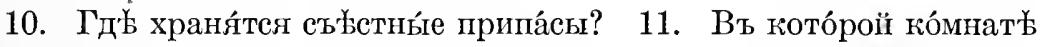
вы ку́шаете? 12. Что въ столо́вой? 13. Что о́коло стола́, и что на столь'

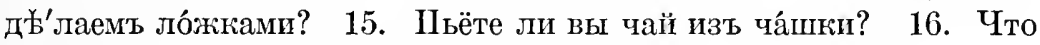

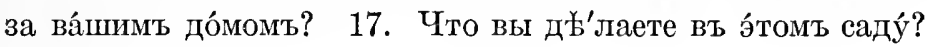

\section{XXXIII}

\section{ТРИДЦАТЬ ТРЕТІЙ УРОКЬ}

\section{TEXT VIII}

\section{Раздтленія времени}

Годъ раздъъляется на двънадцать мъсяцевъ. Вотъ ихъ названія: январь, февраль, мартъ, апръљль, май, іюнь, іюль, августъ, сентябрь, октябрь, ноябрь и декабрь. Въ апръль, іюнъ, сентябрђ и ноябрб тридцать дней, въ февраль двадцать восемь или двадцать девять дней, а въ каждомъ изъ остальныхъ мъъслцевъ тридцать одинъ день.

Семь дней составляють недйлю: Воскресенье, понедъъльникъ, втор- vaskrisen $\varepsilon$, panidelnik, ftornik, razdilenija vremini

got razdilajitsa na dvinatsï $t^{\varsigma}$ mesitsï. vot jix nazvanija: jinvar, fivral, mart, aprel, maj, ijun, ijul, avgust, sintabr, aktabr, najabr i dikabr. - - v aprel $l$, iju $n \varepsilon, \sin t \mathrm{t} b r \varepsilon$ i najibre tritsït $t^{6} d n$ ej, f fivrale dvatsiit vosim ili dvatsït $t^{6} d \mathbf{e} v t^{6}$ dnej, a f každam iz astalnыx mesitsif tritsit $t^{\prime}$ adin $d$ en.

sem $d n \mathbf{e j}$ sastavlajut nidelu: 
никъ, среда, четвергъ, пятница и суббота. Первый день недъллдень праздничный, осталыные дни рабочіе или будни. Въ будни людп работаютъ, а въ воскресенье они отдыхаютъ отъ работъ.

Въ году четрые времени. Первое время года-весна; она начинается двадцать перваго марта н. с. (новаго стиля; восьмого марта с. с. = стараго стиля); второе время, л官то, начинается двадцать перваго іюня, осень двадцать третьяго сентября, а зима двадцать перваго декабря.

День раздъляяется на двадцать четыре часа. На вопрось "Который часъ теперь?" отв Һччаютъ: "Теперь-чась (два часа-песть часовъ и двадцать минуть-половнна восьмого). На вопрось "Которое число сегодня?" отвъччаютъ: "Сегодня двадцать пятое (число) октября (седьмое марта-двадцать третье декабря, и т. д.). srida, čitverk, patnitsa i subbota. pervij den nideli $d \mathbf{e} n$ praznišnыj, astalnыj $\varepsilon d n$ i rabočij $\varepsilon$ ili budni. $\quad \mathrm{v}$ budni $l \mathbf{u} d \mathbf{i}$ rabotajut, a $\mathrm{v}$ vaskrise $n \varepsilon$ ani adduxajut at rabot.

v gadu čitbr $r$ vremini. pervaj $\varepsilon$ vrema goda-visna; ana načinajitsa dvatsït pervava marta novava stila (vasmova marta starava stila). ftaroj $\varepsilon$ vrema goda, leto, načinajitsa dvatsït pervava ijuna, osin dvatsit tretrva sintrbra, a zima dvatsït' pervava dikabra.

den razdilajitsa na dvatsït čitыr $\varepsilon$ čssa. na vapros "katorbj čas tiper?" atvičajut: "tiper-čas (dva čisa-šest" črsof i dvatsït" minut-palavina vasmova). na vapros "katoraj ₹ čislo sivodna?" atvičajut: "sivodna dvatsit" pataj $\varepsilon$ (čislo) aktabra (sid'moj $\varepsilon$ marta-dvatsït tret $\varepsilon$ dikabra, i tak dalij $\varepsilon)$.

\section{NOTES}

Ихъ назва́нія: Свой always refers to the subject of the sentence (36). The non-reflexive possessive pronoun of the third person is егб, ея́, егб for the singular, ихъ for the plural.

Суть: The verb to be is expressed by есть (singular), суть (plural) when there is no predicate noun or adjective, nor an adverbial phrase of place in the sentence.

Въ будии: Въ with the accusative expresses time, especially with the names of days: въ среду́ on Wednesday, во вто́рникъ on Tuesday; similarly въ э́ту мину́ту this minute, въ три часа́ in three hours, во вре́мя (войнб́) during (the war). But the day of the month is expressed by the genitive: вторбого января́ on the second of January.

Но́ваго сти́ля: The Russian (Julian) calendar is thirteen days behind the Western European (Gregorian) calendar, but the latter is being introduced under the name of the 'new style' calendar.

Часъ one o'clock (часъ hour, часы́ watch, clock).

Сегодня today; the first part is the genitive of the demonstrative pronoun ceй, сія́, cië this, the second part the gen. sing. of день; сій is almost obsolete; it occurs in expressions like ciю́ мину́ту this minute, сей ча́съ immediately, до сихъ поръ (gen. plur. of nopá time, term) until now. 


\section{PRONUNCIATION OF NUMERALS}

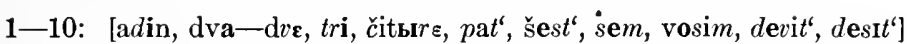

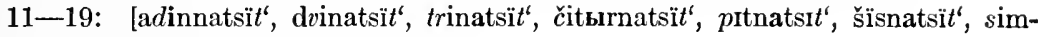
natsi $t^{\prime}$, vasimnatsï $\left.t^{\prime}, d i v i t n a t s i t^{\prime}\right]$

20-90: [dvatsiit', tritsiit' ${ }^{\prime}$, sorak, $p$ Iddisat, šiz $z$ issat, semdistt, vosimdisit, divinosta] 200-1,000: [dvesti, trista, čitïrista, prtsot, šistsot, simsot, vasimsot, divitsot, tïsIča]

Observe the hard consonants in $50-80$ and in $500-900$.

\section{XXXIV}

\section{ТРИДЦАТЬ ЧЕТВЕРТЫЙ УРОКЬ}

\section{The Cardinals. (Study the list of numbers, 128. )}

A. Formation:

11-19: Оди́ннадцать, etc., is contracted from оди́нъ-на-де́сять. Observe the accent and remember that these numbers omit $\mathbf{b}$ in the first part, but retain final $\mathbf{b}$.

50-80: These numbers end in $\mathbf{\mathbf { b }}$ (твёрдый знакъ) because they

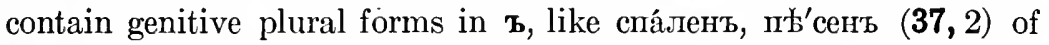
десять; пять-деси́ть = five decades; the $\mathbf{b}$ of the first part is not pronounced.

Cópoкъ is abbreviated from Greek tessarakonta ' 40 '; it replaced older чети́pдесятъ because of the frequent occurrence of the Greek numeral 40 in Orthodox liturgy.-Девяно́сто meant originally 'a hundred based on nines' (instead of tens). 200-900, 2000-900,000: -сти is an old dual form of сто (see below, В), ста and ти́сячи are nominative plural forms, сотъ and ти́сячъ genitive plural forms.

B. Syntax:

1. (три́дцать) оди́нъ день.

2. два-три-чети́ре часа́; два́дцать два дня.

3. семь-два́дцать-три́дцать дней.

Два, три, четь́ре, and compound numbers ending in 2, 3, 4 are followed by the genitive singular; одинъ and compound numbers ending in 1 , by the nominative singular; numbers from пять on, by the genitive plural.

Note 1.-The apparent gen. sing. after $2,3,4$ is really an old dual ( $(9)$, which originally belonged only to два, двъ.

Nore 2.-Adjectives stand in the nom. or gen. plur. after 2, 3, 4: двъ русскія кни́ги (gen. sing. of кни́га) or двъ ру́сскихъ кни́ги; after higher numerals, they stand in the gen. plur., like nouns: шесть ру́сскихъ книгъ. Substantivized adjectives are treated in the same way: двъ етолб́выя оr столб́выхъ, де́сять етоло́выхъ. 
C. Declension: See paradigms, $\uparrow 28$.

The declension of 2, 3, 4 is based upon old dual forms, originally belonging to the number 2 only.

The other numbers are regular nouns, being declined like тетра́дь (пять, шесть, etc.), or like доска́ (ти́сяча), or like столъ, сло́во (милліо́нъ, сто). However, with cópoкъ, сто, девяно́сто the genitive ending a has been transferred also to the dative, locative, and instrumental: со ста ти́сячамп человъ'къ with one hundred thousand men (co with requires the instrumental).

Accent: $5-10,20,30,40$ have the accent on the ending in the declined forms: пяті́, восемью́; 11-19 do not change the accent.

1. Write the following numbers in words: 371, 64329, 94, 9025, $721,8216,27$.

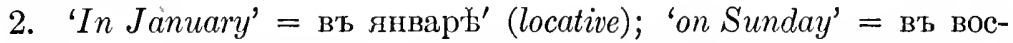
rpecéuie; 'on Saturdays' = по суббо́тамъ; connect in the same way the names of the other eleven months and of the other six days of the week with the prepositions $\mathrm{B} \mathrm{b}$ and nо.

3. Connect the following expressions with the prepositions $\mathrm{B}$ ( and acc.) and изъ (gen.): 3 комнат-, 7 дом-, 16 книг-, 24 я́щик-.

4. Decline: 7 days, 24 knives, 16 windows, 4 dining-rooms, 2 houses.

\section{XXXV \\ ТРИДцАТЬ ПЯТЫЙ УРОКЬ}

42. The Ordinals. (Study the list, 129. . $^{\circ}$

The ordinals are regular adjectives in ой or ыï and are declined as such. Only тре́тій is slightly irregular: The nom. masc. sing. ends in $\mathbf{i и ̆}$, the other cases in $\mathbf{b}+$ soft ending. See $\uparrow 26$.

\section{Lengthened Noun Stems:}

$\begin{array}{llll}\text { и́м-я } & \text { и́м-ен-и } & \text { мать } & \text { ма́т-ер-и mother } \\ \text { вре́м-я } & \text { вре́м-ен-и } & \text { дочь } & \text { до́ч-ер-и daughter. }\end{array}$

Имя, and about half a dozen common nouns of the same type correspond to Latin nouns like homo-hominis or German nouns like Name-Namens, final $n$ being dropped in the nom. sing.; likewise final $r$ was apocopated in the two nouns мать and дочь.

1. Decline: (a) his (their, her) name (reflexive possessive), my (our) mother, your daughter, the new time.

(b) The first lesson, the third day, the fifth floor.

2. Write in words: Sept. 1, 1919 (ти́сяча девятьсоть девятна́дцатаго го́да); Jan. 16, 1843; March 18, 1876; December 24, 800; April 1, 1618. 


\section{XXXVI}

\section{ТРИДЦАТЬ ШЕСТОЙ УРОКЬ}

\section{Вопросы}

1. Ско́лько мъ’сяцевъ въ году́? 2. Какъ ихъ назва́нія? 3. Ско́лько дней въ ка́ждомь м'ъ'сяць'? 4. Ско́лько дней состав-

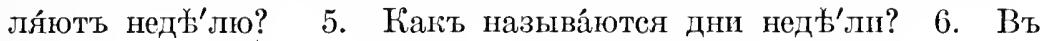
какі'е дни лю́ди рабо́таютъ? 7. Что они́ ды'抽т'ь по воскресе́ньямъ? 8. Ско́лько времён'ъ го́да? 9. Какъ пхъ назва́нія? 10. Когда́ начпна́ется ка́ждое вре́мя го́да? 11. Сћóлько часо́въ

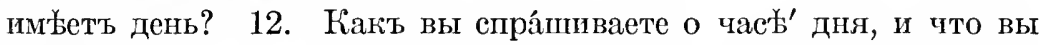
отвъ̌ча́ете на тако́й вопро́съ? 13. Что вы отвъ̆ча́ете на вопро́съ

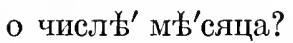

\section{XXXVII}

\section{ТРИДЦАТЬ СЕДЬМОЙ УРОКЬ}

This text is intended merely as a reading exercise, and not as a basis for grammatical work or for practice in speaking. No phonetic transcriptions are given from now on, but special difficulties are explained in the notes; besides, the pronunciation of every word is indicated in the word-list at the end of the book.

\section{Главный выигры шъ}

Одни́мъ второ́го января́

Счастли́вцемъ бо́л'̌e, нб̛́тъ спо́pa,

Но, открове́нно говоря́,

Его́ узна́емъ мы не ско́ро,

И двухъ-сотъ-ть́сячный биле́тъ

По достов Ђ’'рнбйшамъ разска́замъ

И сообше́ніямъ газе́тъ

У мно́гихъ лицъ найдётся ра́зомъ.

Поди́-ка, пра́вду разбери́!

Счастли́вецъ тотъ живётъ въ Калу́гћ̆,

Въ Ташке́нть̌́, въ Во́логд⿱⺊口冋, в’ Твери́,

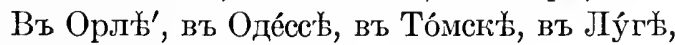

Въ Баку́, въ Сара́товъ, въ Москвъ́,

Въ Тифлиі́сł, въ Ха́рьковъ́, въ Сызра́нп,

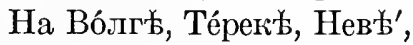

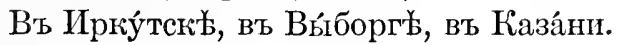


Арте́льщикъ, пи́сарь, биржеви́къ,

Столя́рь, моло́чица, сапо́жникъ,

Купе́цъ, реме́сленикъ, ямци́къ,

Куха́рка, бу́лочникъ, худо́жникъ,

Чино́вникъ, пра́порщикъ, поэ́тъ,

Жена́ дьячка́, дочь букини́ста.

Коро́че, на оди́нъ биле́тъ

Вамъ назову́тъ счастли́вцевъ три́ста.

\section{NOTES}

L. 1-2: Однймъ...... счастли́вцемъ, instrumental of measure: There is (on the $2 d$ of January) one lucky chap more.-On January 2, there used to be a public lottery in Petrograd, with a first prize of 200,000 rubles.

2. Н'ъть cпópa there is no quarrel, there can be no doubt.

3. Говор $\hat{\text {, }}$ present participle of говори́ть.

4. Узна́емъ has future meaning.

8. Найдётся, reflexive with passive force, will be found.

9. Поди́ (for пойди́), разбери́, imperatives; -ка, emphasizing particle.

10-16: Names of Russian cities: Калу́га, Ташке́нтъ, Вблогда, Тверь, Орёлъ, Оде́сса, Томскъ, Ју́га, Баку́ (indeclinable), Сара́товъ, Москва́, Тифли́съ, Ха́рьковъ, Сызра́нь, Ирку́тскъ, Ви́боргъ, Каза́нь; of Russian rivers: Вблга, Те́рекъ, Не́ва.

17. Supply $H$ e is......

24. Счастли́вцевъ три́cra: If the numeral follows its noun, it denotes an approximate number: челов屯'къ пятьдеся́ть about fifty people.

Pronunciation.
2. [ščrsliftsïm bolije]
20. [bulašnik]

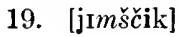
22. [žĩna $d$ jıčka].

The reading of metrical texts is one of the greatest helps for learning the Russian accent. Deviations from prose accent are rare.

\section{TEXT IX}

\section{А. Зима}

Гдъ сла́дкій шо́потъ

Мои́хъ л实óвъ?

Пото́ковъ ро́потъ,

Цвъ̆ти́ луго́въ?

Дере́вья го́лы;

Ковёръ зимь́

Покри́лъ холми́,

Луга́ и до́лы;
Подъ ледяно́й

Свое́й коро́й

Руче́ї нбан'етъ;

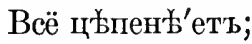

Лишь в 'ъ'теръ злой

Бушу́я во́етъ

И не́бо кро́етъ

СЊдо́ю мглой.

Барать́нскій. 


\section{Б. Русскій языкъ}

Во дни сомн'ъ'ній, во дни тя́гостныхъ разду́мій о судьба́хъ мое́й ро́дины-ты оди́нъ мнґъ подде́ржка и опо́ра, о вели́кій, могу́чій, правди́вый и свобо́дный ру́сскій язи́къ!-Не будь тебя́-какъ не впасть въ отча́яніе, при ви́дъ всего́, что соверша́ется до́ма?Но нельзя́ в‘́'рить, что́бы тако́ї язы́къ не́ былъ данъ вели́кому наро́ду.

И. С. Турге́невъ.

\section{XXXVIII}

\section{ТРИДЦАТЬ ВОСЬМОЙ УРОКЪ}

\section{NOTES}

A.-L. 3, 4. Supply гд⿱⺊口 where is.

7. Покри́лъ, preterit of покри́ть has covered.

13. Въ'теръ злой: Postposition of the adjective occurs sometimes in poetry.

14. Бу шу́я, present participle of бушева́ть.

B.-Ты оди́нъ Thou alone (art).

Не будь тебя If it were not for thee, But for thee. (Будь is the imperative of быть let there be, тебя́, partitive genitive of thee).

Какъ не впасть, infinitive of possibility: How would it be possible not to fall...

Чтоббы...... не́ былъ данъ that...... should not have been given.

\section{XXXIX \\ ТРИДЦАТЬ ДЕВЯТЫЙ УРОКЬ}

\section{Irregular Plurals:}

1. A number of masculines have plurals in $\mathbf{a}-\boldsymbol{\Re}$ (always accented). This was originally a dual ending ( 9 ), as can still be inferred from its frequent occurrence with the names of things that generally occur in pairs; but its use has been extended to many other nouns; e.g.:

Pairs:

глазъ еуе—глаза́ бéper”s shore-берегá рогъ horn-рога́ бокъ side—бока́
Other Nouns:

домъ house-дома́ лугь meadow-луга́ го́родъ city一города́ учи́тель teacher-учителя́.

The genitive plural of these nouns generally ends in $\mathbf{\mathbf { b }}$ : глазъ (but учителе́ї). They are treated as masculines as far as the agreement of adjectives and pronouns is concerned: чёрные глаза́, больші'е дома́.

2. A few masculines and neuters have plurals in $\mathbf{~}$, , e.g.: брать brother-бра́тья, стуль-сту́лья, другь friend-друзья́, де́рево一дере́вья, перо́-пе́рья.

Other irregular plurals are given in $\uparrow 14,5$, and $\uparrow 16,2$. 
45. Personal Pronouns.-Most of the forms have occurred in the texts. Study the complete paradigm, $\mathbf{\top} 17$.

1. The forms of the third person prefix an $\mathbf{H}$ after prepositions governing them: для него́.for him, къ нему́ to him, въ нихъ in them, съ ни́мп with them.

When the pronoun is not governed by the preceding preposition, the $\mathbf{н}$ is not used: на его́ стол'ъ' upon his table-because на governs етол'ъ, which is modified by его́.

2 . The difference between the acc. and gen. sing. fem. is purely orthographic; both are pronounced [jijo].

3. The genitive is used for the aceusative under all cireumstances, whether things or animate beings are referred to.

4. Его́, еи́, ıххъ are used as possessives not referring to the subject of the sentence (like Latin eius, eorum), while евой $(35,36)$, like Latin suus, refers to the subject: Я пи́шу въ его́ тетра́дп $I$ am writing in his notebook, он' пи́шетъ въ свое́й тетра́ді he is writing in his (own) notebook.

5. Себи́, себъ', соббй, like свої and -ся, -сь, stand for all persons and numbers, Я зна́ю себ́́ I know myself, мы лю́бпмъ себя́ we love ourselves.

The reflexive -ся, -сь is a shorter form of себ́́ (себ́ $\left.\mathbf{b}^{\prime}\right)$.

6. The difference between ты and вы is the same as between French $t u$ and vous, ты being used in speaking to near relatives, friends, animals, and in elevated speech, вы in more or less formal intercourse.

46. Definitive Pronouns.-This term-translating опредҺ́ли́тельныя м'ьстоимь'нія-comprises in Russian grammar the words for self, same, all, one, a certain, alone, each. Ка́ждый, вся́кій each, every, and са́мый same, have regular adjective declension, and the others differ but little:
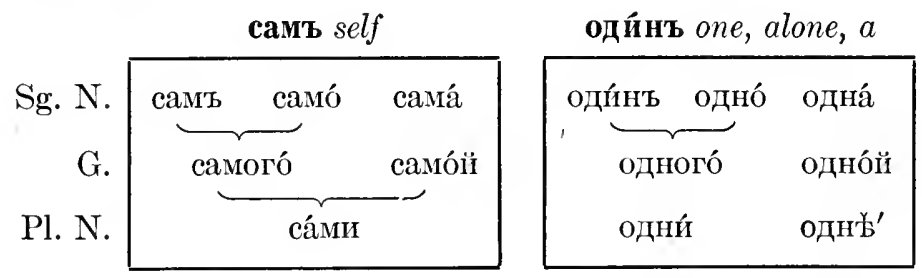

With the exception of the nom. sing. and plur. the forms are like those of 'э́тоть, but with the accent on the last syllable, e.g., самому́, однйхъ, like своегó, своемý, not like большо́го, большо́му.

Въсь all goes like онъ in the oblique cases, but has the vowel $\mathbf{b}$ where онъ has the vowel и: всего́, всёмъ; всъмъ, всъхъ. The acc. sing. fem. is вcю, the nom. plur. вe for all three genders. The acc. sing. masc. and the acc. plur. follow the rule for adjectives.

For complete paradigms, see $₫ 23$.

1. Decline, (a) in the singular only: оди́нъ язи́ къ, весь наро́дъ, э́та зима́, ка́ждая нед‘'‘'ля. 
(b) In the singular and plural: ка́ждый день, своё кре́сло, э́тотъ лугъ.

2. Continue through all persons, numbers, and genders:

(a) without me (without thce,....him,....her, ctc.), to me, near me (при with loc.), with me (съ with instr.).

(b) I have two houses. I need a comb. I need a razor. I need a mirror. (Compare: У кого но́жнкъ? Who has a pocket-knife? комý ну́женъ но́жикъ who needs a pocket-knife?-Нуженъ, нужна́, ну́жнор.)

3. Memorize the two texts.

\section{$\mathrm{XL}$ \\ СОРОКОВОЙ УРОКТ}

REVIEW

1. Write in Russian, using words for all numerals: February 28 , 1917, at eleren o'clock; January 31, 1849; December 15, 1760.17 people, 32 days, 4 weeks, 144 pens, 240 pencils, 2500 houses, 100 families.

2. Decline in the singular and plural: Our dining-room, a small bathroom, this guestroom, three bedrooms, a clean glass, this high tree, your beautiful garden.

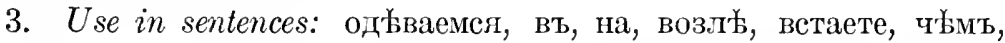
моетесь, у меня, идетъ, свою, него, воды, крынп, ея, лежатъ, будни, будетъ, онъ, однь, дня, часа, года.-Place accent marks on all words.

4. Answer in Russian:

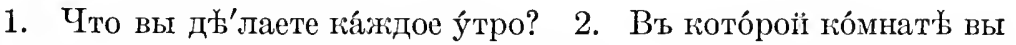
одъва́етесь, а въ кото́рой вы за́втракаете? 3. Изъ чего́ состои́тъ у васъ за́втракъ? 4. Какови́ назва́нія разд ঝ̇ле́ній го́да; двъна́-

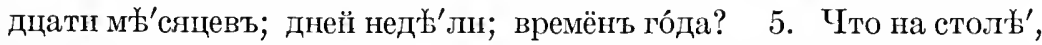
когда́ вы объ’даете? 6. Ско́лько дней въ году́, а ско́лько въ ка́жддомъ мъ’'сяцъో? 7. Кото́рый часъ тепе́рь? 8. Въ кото́ромъ часу́ вы объ'даете обыкнове́нно? Въ кото́ромъ часу́ вы у́жннаете? 9. Когда́ вы пдёте спать? 10. Ско́лько часо́въ пмъ́'еть день? 11. Съи́лько дней составля́тоть нед安'лю? 12. Кото́рое число́ сего́дня?

5. Compile from memory a complete table of all noun and adjective endings and state the differences between the declensions of possessive, demonstrative, and definitive pronouns, and that of common adjectives. 


\section{TEXT X}

\section{А. Что знаешь, о томъ не спра шивай}

Оди́нъ мужи́къ везётъ возъ съ'на, а друго́й идётъ ему́ навстрђ'чу. “Здра́вствуй, Ива́нъ!”-“Здра́вствуй, Пётръ! А что везёшь?”“Дрова́ везу́, хоро́шія дрова́."-“Какі'я дрова́, въъдь у тебя́ съъ'но!"

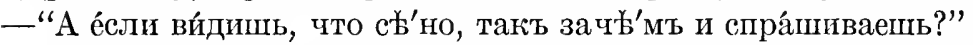

Тогда́ Ива́нъ почеса́лъ го́лову и поду́малъ: “А въдь впра́вду, для чего́-жъ я и спра́шивалъ?"

\section{Б. Тише ьдешь-дальше будешь}

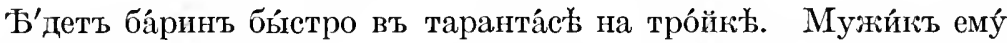
навстрбъ'чу, и ба́рннъ спра́шиваетъ у него́: “Далёко ли до го́рода?" -Мужи́къ смо́тритъ на колёса таранта́са и говори́тъ: "Если

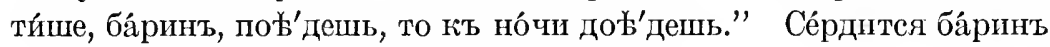

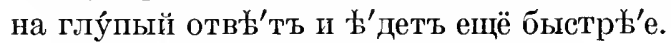

Но ско́ро пере́днее колесо́ лома́ется. Къ сча́стью, недалёко отъ доро́ги ку́зница; кóe-каюъ туда́ тя́нуть таранта́съ, и кузне́цъ чини́тъ его́ цвилый день̨.

То́лько на друго́й день къ но́чи ба́ринъ пріђзжа́етъ въ го́родъ.

\section{XLI \\ СОРОКЬ ПЕРВЫЙ УРОКЂ}

\section{NOTES}

A.—О томъ: Loc. sing. of dem. pron. тотъ, declined like э́тотъ; this pronoun is chiefly used as an antecedent of a relative clause.

Въдь: Russian possesses an abundance of particles giving sentiment and color to the sentence. They are often untranslatable; in this case, the meaning is something like: Why, it's hay you have on your wagon!

Такъ often connects the conclusion of a hypothetical period with the conditional clause (like German so).

А въдь впра́вду Why, indeed, Why, sure enough.

Чеѓ́-жъ: жъ, же, emphasizing particle.

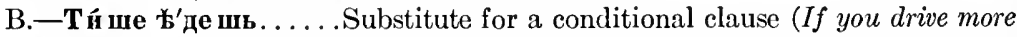
slowly, you will get farther). Russian popular language has a preference for coordination of sentences.

Сіра́ шиваетъ у негó: Notice the construction.

Чи́нитъ его́ цұлый день: Works all day repairing it.

Къ но́чи towards nightfall. 


\section{XLII}

\section{СОРОКЂ ВТОРОЙ УРОКЂ}

\section{Formation of the Present:}

The following verbs - arranged according to the form of the third singular-have occurred in the texts:

\section{A. Vowel +er's}

a(я)—тъ: ду́ма-етъ, д'́'ла-етъ, чита́-етъ, гуля́-етъ, объясня́-етъ, купа́етъ, лома́етъ, раб́́таетъ, слу́шаетъ, спра́шиваетъ, зна́етъ, вызыва́етъ, вынима́етъ закрыва́етъ, нзуча́етъ, начина́етъ, одъва́етъ, отвђча́етъ, отдыха́етъ, открыва́-, етъ, понима́етъ, приготовля́етъ, причёсываетъ, продолж:́́тъ, соверша́ется, составля́етъ, съъ'даетъ.

a +ёть: да-ётъ, вста-ётъ.

о +етъ: мо́етъ, кро́етъ, вбетъ.

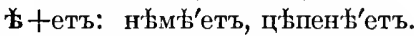

у Нетъ: здра́вствуетъ, пожа́луетъ.

ь十ётъ: пьёть.

\section{B. Consonant +ers}

бу́детъ, ‘’детъ, тя́нетъ, пи́шетъ, хо́четъ; идётъ, кладётъ, падётъ, везётъ.

II. итъ

у читъ, говори́тъ, благодари́тъ, тбчитъ, храни́тъ, в势ритъ, стои́тъ, чи́нитъ, де́ржитъ, лежи́тъ, перевб́дитъ, хб́дитъ, сади́тся, се́рдится, чи́ститъ, ви́дитъ, виси́тъ, смб́тритъ, лю́битъ, спитъ.

There are two conjugations. Their endings for the present indicative are:

$\begin{array}{rrrrrl}\text { I-ю, y } & \text { ешь } & \text { еть } & \text { емъ } & \text { ете } & \text { ють, уть } \\ \text { II-ю, y } & \text { ишь } & \text { ить } & \text { имъ } & \text { ите } & \text { ять, ать }\end{array}$

The use of ю-ять or $\mathrm{y}$-ать in the second conjugation depends entirely on the rules of vowel variation, the soft vowels being used whenever permissible: rоворю́, говоря́тъ, but держу́, де́ржатъ. But in the first conjugation the hard vowels may occur after any consonant.

The infinitive is not a safe indication of the conjugation of a verb. It is a verbal noun that must be studied as such. For each Russian verb the infinitive and the first 'and second (or third) person singular present must be learned - the rest follows.

The first conjugation is subdivided into a vocalic class (I A) and a consonantic class (I B), depending on whether the personal endings are preceded by a vowel or a consonant; thus ды'

1. Review the text.

2. Locate each verb listed in this lesson in the texts.

3. Use each of these verbs in a sentence.

4. Conjugate the present tense of знать, купа́тся, дава́ть, пить, имъ'ть', итти́ (иду́), пасть, учи́ться, стоя́ть, держа́ть. 


\section{First Conjugation. A. Vocalic Class :}

The endings are $\mathbf{ю}$, ешь, етъ, ем' is generally а-я. To this class belong the great majority of the verbs in aTr, especially most of the verbs with stems in $\pi, \mathrm{H}, \mathrm{p}, \mathrm{L}, \mathrm{r}, \mathrm{B}$, e.g.,

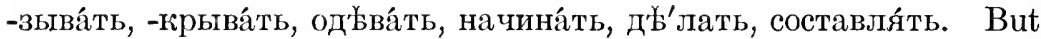
there are also many verbs in other consonants in this class, e.g., понима́ть, купа́ть, съł'дать, рабо́тать, лома́ть, ду́мать, отдыха́ть, соверша́ть, продолжа́ть.

NoтE: Scientific grammar recognizes a sharp distinction between verbs where this a is a connecting vowel between root and ending, such as д $\mathbf{b}^{\prime} л-\mathbf{a}-\mathbf{T} \mathbf{b}$, from д work, рабо́т-а-ть, from рабо́та labor, and those where it belongs to the root, e.g., зна-ть. But for the purposes of an elementary grammar this distinction is without consequence.

Verbs with infinitives in авать have the accent on the ending: дава́ть даю́, даёшь; става́ть-стаю́, стаёшь.

Vowels other than a before the ending are comparatively rare; for instance, see 47, I A. The most important types are those in 'bTb and those in овать. Verbs in бть are generally inchoatives, i.e., they denote incipient action or condition: нумм'

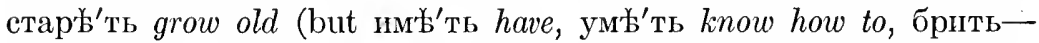
брь'ю shave). Verbs in овать form presents in ую, уешь and include, among others, many verbs borrowed from other languages, e.g., танцова́ть dance, from German tanzen, аплоди́ровать applaud (танцу́ю, -у́ешь; аплоди́рую, -уешь).

\section{First Conjugation. B. Consonantic Class :}

The endings of the first singular and third plural appear at present as $\mathbf{y}, \mathbf{y т b}$ with almost all verbs, ${ }^{1}$ but the effect of former ю, ють is still seen in certain consonant changes $(\mathbf{5 0}, \mathbf{5 4})$. Verbs with infinitives in ть after consonant or in ти add these endings without any consonant change (cf. 50):

\begin{tabular}{llll}
\multicolumn{1}{c}{ Inf. } & 1st Sing. & 2d Sing. & 3d Plural \\
класть & кладу́ & кладёшь & кладу́ть \\
пасть & паду́ & падёшь & паду́ть \\
везти́ & везý & везёшь & везу́ть \\
итти́ & иду́ & идёшь & иду́ть
\end{tabular}

${ }^{1}$ ю, ють after л, p: шлю, шлёшь.....шлють, inf. слать send; дремлю́, дре́млешь..... дре́млють, inf. дрема́ть slumber. 
Other infinitive forms:

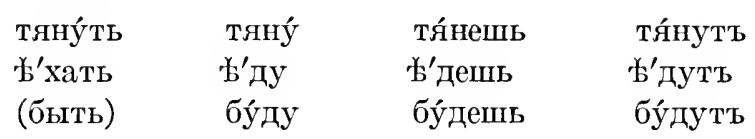

1. Review the text.

2. Write the complete present conjugation of the verbs listed in this lesson.

3. Write the plural form of each inflected word in text X (e.g., оди́нъ 一одни́, мужіи́къ-мужики́, везётъ-везу́тъ).

\section{XLIV \\ СОРОКЬ ЧЕТВЕРТЫЙ УРОКЬ}

50. Consonant Softening.-The velars $(\kappa, r, x)$, the dental sibilants $(c, 3)$, and the dental stops $(\mathrm{T}, \mathrm{I})$ are under certain conditions changed to palatal sibilants under the influence of following soft vowels. The voiced consonants remain voiced, the voiceless ones remain voiceless; $\kappa$ and $\mathrm{T}$ retain partly their character as stops, becoming ч $[\check{c}=t$-š].

Thus the following changes result:

\begin{tabular}{|c|c|}
\hline $\mathbf{r}, \boldsymbol{A}, \mathbf{3}$ & become \\
\hline $\mathbf{K}, \mathbf{T}$ & " \\
\hline $\mathbf{c}, \mathbf{x}$ & "6 \\
\hline ск, ст & \\
\hline
\end{tabular}

This phonetic process is termed Softening of Consonants.

Labials are softened, not by any change of their articulation proper, but by the insertion of $\pi$ before the soft vowel, e.g., $б$ †ю $=$ блю.

In the older language, consonant softening took place before all soft endings. Traces of this are still apparent in such irregular plurals (or, rather, duals) as ок6 eye-óчи, ýхо ear-у́ши ( 99 ); they are frequent in word derivation, e.g., Богъ

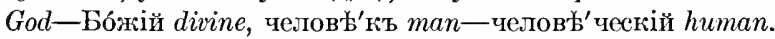

In two grammatical categories, the comparison of adjectives, and the conjugation, consonant softening is still a living element of inflection.

\section{The Predicative Comparative:}

Быстръ'e, да́ль ше, ти́ ше (X B), да́лłe (IV), коро́че (Lesson 35).

The comparative, like the positive, has a shorter (uninflected) form when used predicatively, and a longer, inflected form, when used attributively. 
The predicative comparative is generally formed by adding to to the stem:

би́стрый fast-быстрб'e (note the accent; no rule)

краси́вый beautiful-красі́в'ъe

дли́нный long-длинн'ъ'e

Adjectives ending in consonants subject to softening undergo the changes stated in the preceding paragraph, and te becomes e after the softened consonants:

дорого́і̆ dear, expensive-доро́же

коро́ткій short-коро́че

чи́стый clean-чи́ ще

Suffixes are often omitted:

высо́кій high-ви́ ше

у́зкій narrow-ýже

просто́й plain-про́ще

бога́тый rich一бога́че

широ́кій wide-ши́ре

Irregular forms:

большо́й big一бо́льше (as adverb, бо́лЊืe)

ма́лый small-ме́ныше (as adverb, мéнłъe)

хоро́шій good-лу́ чше

English than is expressed (1) by чььм or не́жели, (2) by the genitive of compar-

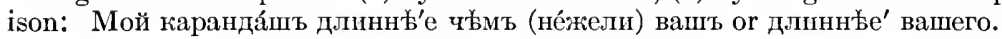

52. Adverbs.-Russian has no particular adverb termination. Generally the neuter singular of the predicative form is used adverbially: Онъ пи́шетъ хорошо́ (пло́хо).

Some soft adjectives form adverbs in o (instead of e), e.g., páннiй early-ра́но, да́вній former-давно́ long ago.

Adjectives in -скій have adverbs in -ски: дру́жкескій friendly, ирони́ ческій ironical一дру́жески, ирони́ чески.

With names of languages of this form, the prefix no- is used: noру́сски, по-а́нгліійски. This adverbial form is also used in sentences like я зна́ю по-ру́сски $I$ know Russian, я говорю́ по-ру́сски $I$ can speak Russian, я не понима́ю по-ру́сски $I$ do not understand Russian.

With the predicative comparative, there is no special form for the

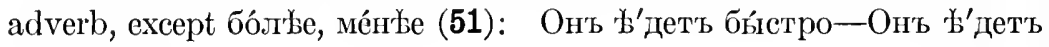
бысртты'е.

1. Review the text.

2. As far as the meaning admits, form the predicative comparatives and the adverbs of the adjectives that have occurred in the texts and use them in independent sentences; refer to the general word-list for the correct comparative forms. 


\section{XLV}

\section{СОРОКЂ ПЯТЫЙ УРОКЬ}

\section{Вопросы}

1. Кака́я посло́вица загла́віе э́того те́кста? 2. Кто везётъ возъ

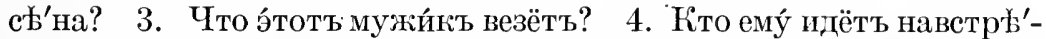
чу? 5. Что говори́тъ второ́й мужи́къ? 6 . Что пе́рвый мужи́́къ отвђча́етъ? 7. Говори́тъ ли пе́рвый мужикъ, что онъ везёть съ'но? 8. Что онъ впра́вду везётъ? 9. Что Ива́нъ д'ъ'лаетъ на отвЊ'ть Петра́?

10. Кака́я посло́вица загла́віе второ́го те́кста? 11. Кагъ э́тотъ

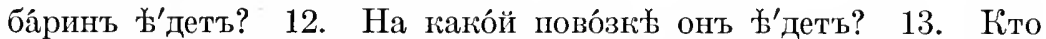
идётъ ему́ навстрђ'чу? 14. Что ба́ринъ спра́шиваетъ у него́? 15. Что мужи́и ды'

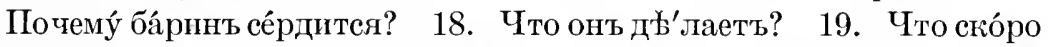
случа́ется? 20. Гдъُ нахо́дится ку́зница? 21. Кто въ б́той ку́зницъ? 22. Что онъ дъ'่'лаетъ цъ'лый день? 23. Когда́ наконе́цъ ба́ринъ пріњзжа́етъ въ го́родъ?

\section{TEXT XI}

\section{Пётръ Ій и мужи́къ}

Наб̆'ха́ль царь Пётръ на мужика́ въ льсу́. Мужи́къ дрова́ ру́битъ. Царь говори́тъ: “Бо́жья по́мощь, мужии́къ!"

Мужи́къ и говори́тъ: “И то мнъ̆ нужћна́ Бо́жъя по́мощь."

Царь спра́пиваетъ: “А велика́ ли у тебя́ семья́?”

-У меня́ семья́ два сь́на іп двЊ́ до́чери.

- Ну, не велико́ твоё семе́йство. Куда́ жъ ты де́ньги кладёшь?

-А я де́ньги на три ча́сти кладу́: Во пе́рвыхъ-долгъ плачу́, во втори́хъ-въ долгъ даю́, в'ъ тре́тьихъ-въ во́ду мечу́.

Царь не понима́етъ, что э́то зна́чнтъ, что стари́єъ и долгъ пла́титъ, и въ долгъ даётъ, и въ во́ду ме́четъ.

А стари́къ говори́тъ: "Долгъ нлачу́-отца́ и мать кормлю́; въ долгъ даю́-сынове́й кормлю́; а въ во́ду ме́чу-дочере́ї рощу́."

Царь и говори́тъ: “У'мная твоя́ голова́, старичо́ґъ. Тепе́рь ви́веди меня́ въ по́ле, я доро́ги не найду́.” Мужіи́къ говори́тъ: "Найдёшь Іі самъ доро́гу; пди́ пря́мо, пото́мъ сверни́ впра́во, а пото́мъ влЂُ во, пото́мъ опя́ть вгіра́во."

Царь и говори́тъ: “Я э́той гра́моты не понима́ю, ты сведи́ меня́!” 
-Мнб, су́дарь, води́ть не́когда; намъ въ крестья́нствъ̌ день до́рого сто́нть.

- Ну, до́рого сто́итъ, такъ я заплачу́.

-А запла́тишь-пойдёмъ.

Съ'ли на одноко́лку, поъ'十'хали.

Сталъ доро́гою царь мужика́ спра́шивать: “Дале́че ли ты, мужиичо́къ, быва́лъ?"

-Кóe-гд冬 быва́лт.

-А вІда́лъ ли цари́?

- Царя́ не вида́лъ, а на́до-бъ посмотр'ъ'ть.

-Такъ вотъ, какъ вы́'九демъ въ по́ле,-пп уви́дишь царя́.

- А какъ́ я его́ узна́ю?

-Веæъ безъ ша́покъ бу́дутъ; оді́нъ царь въ ша́пк‘.

Вотъ пріъ'халп они́ въ по́ле. Увида́лъ царя́ наро́дъ-всъ снима́ли ша́пки. Мужи́къ пя́лить глаза́, а не ви́днтъ царя́. Вотъ онъ и спра́шиваетъ: “А гдъ же царь?”

Говори́тъ ему́ Пётръ Алексъ’евичъ: “Ви́дишь, то́лько мы дво́е въ ша́пкахъ-кто-нибудь пзъ насъ да царь!”

\section{XLVI \\ СОРОКЂ IIЕСТОЙ УРОКЂ}

\section{NOTES}

Мужикиъ и говори́тъ: $\boldsymbol{n}$ is a popular connective, weaker than English and then.

У меня́ семья́...... I have a family of ......

Во пе́рвыхъ first, in the first place, во вторйхъ second(ly).

A: a somewhat stronger connective than $\mathrm{n}: W e l l, I \ldots \ldots$

Старичб́къ, мужичо́къ are instances of the very frequent use of diminutives in familiar intercourse.

Доро́гп не найду́ : After negative verbs the direct object stands in the genitive, instead of the accusative.

Самъ by yourself.

Су́дарь is (or was) used in by servants addressing their masters; compare Harper's Reader, Remark 45.

Мнъ́ не́когда I have no time.

А запла́ти шь [zaplotiš] $O h$, well, if you are going to pay......

Пойдёмъ Let's go.

Дале́че rather far.

Ко́е-гдъ быва́лъ I have traveled quite a bit.

На́до-бъ (-бы) it would be necessary for me to see him, I should like to see him.

Какъ его́ узна́ю How am I going to recognize him?

Bъ шánḱ will have his hat on.

Мы дво́е the two of us, you and $I$. 
New Verbs:

IA - none.

IB-мета́ть-мечý, ме́чешь

(вы)вести́-веду́, ведёшь верну́ть-верну́, вернёшь

II-зна́чнть-зна́чу, зна́чишь плати́ть-плачу́, пла́тишь ${ }^{1}$ пя́лить-пялю́, пя́лишь расти́ть-ращу́, расти́шь води́ть一вожу́, во́дишь руб̆і́ть-рубблю, ру́бишь корми́ть一кормлю́, ко́рмншь.

$\mathbf{1} \mathbf{a}$ in this verb is pronounced [o] whenever accented.

\section{XLVII \\ СОРОКЂ СЕДЬМОЙ УРОКЂ}

53. Second Conjugation.--The endings are ю, ишь, итъ, имъ, ите, Ятъ; through vowel variation, the 1 st sing. and $3 \mathrm{~d}$ plur. may end in $\mathrm{y}$, атъ (е.g., учи́, у́ чатъ).

\section{Inf.}

говори́ть

держа́ть

смотрњ'ть

\section{1st Sing.}

говорю́

держіу́

смотрю́
$2 d$ Sing.

говори́шшь

де́ржишь

смо́тришь 3d Plur.

говоря́тъ

де́ржатъ

смо́трятъ.

\section{Presents with Consonant Softening:}

First Consonontic Conjugation:

\section{Inf.}

a. мочь be able течь flow

\section{Present}

$\mid \begin{aligned} & \text { могу́ } \\ & \text { текý }\end{aligned}$ мо́жешь, жетъ, жемъ, жете мо́гутъ те́кутъ

Likewise лечь lie down-лгу, лжёшь; влечь draw-влеку́, чёшь, etc.

b. мета́ть мечу́, ме́чешь, четъ, чемъ, чете, чутъ писа́ть пи шу́, пи́шешь, шетъ, шемъ, шете, шутъ каза́ть show кажу́, ка́жешь, жетъ, жемъ, жете, жуть.

Likewise płъáть cut-pb'жу, pł'жешь; пла́кать weep-пла́чу, чешь лгать lie, prevaricate-лжу, лжёшь; слать send-шлю, шлёшь, etc.

Second Conjugation:

\begin{tabular}{|c|c|c|}
\hline $\begin{array}{l}\text { води́ть } \\
\text { плати́ть } \\
\text { расти́ть } \\
\text { руби́ть }\end{array}$ & $\begin{array}{l}\text { вожу́ } \\
\text { плачý } \\
\text { ращý } \\
\text { рублю́ }\end{array}$ & 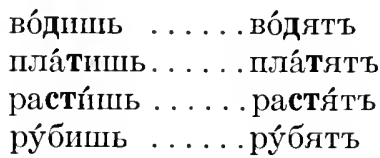 \\
\hline
\end{tabular}




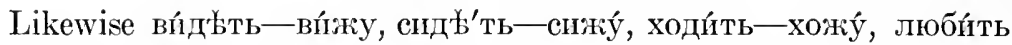
一люблю́, висъ'ть-вишу́, носи́ть-ношу́, пусти́ть-пущу́, etc.

An examination of these verbs results in the following rules:

1. Verbs of the First Consonantic Conjugation soften the final stem consonant

-in all persons, if the infinitive ends in $\mathbf{a T b}$;

-in all persons except the 1st sing. and $3 \mathrm{~d}$ plur., if the infinitive ends in $\mathbf{4} \mathbf{b}$.

NoTE: There is no convenient rule to decide whether a verb in aтb belongs to I A, I B, or II (д'ъ'лать-ппеа́ть-держа́ть); it must be learned.

2. Verbs of the Second Conjugation soften the consonant in the 1st sing. only.

1. Conjugate in full the present tense of all new verbs in this text.

2. Write the plural form of each singular noun and adjective in the text in the same case.

3. Decline: Бо́жьья по́мощь (singular only), ва́ша семья́, вели́кій царь, широ́кое по́ле.

4. Change to the negative form: Мужииє црова́ pýӧнтъ. Я де́ньги въ во́ду мечу́. Мужи́къ сншма́лъ ша́пку.

5. Continue through all persons: Мн务 нужна́ Бо́жья по́мощь. У меня́ вели́ккая семья́. Мнб̆ не́когда чита́ть.

\section{XLVIII .}

\section{- СОРОКЂ ВОСЬМОЙ УРОКЂ}

\section{The Imperative:}

1st Sing. Sing. Imp.

A. Іाдý (I B)

пишу́

cIIжiý (II)

сплно трйкну

B. бу́ду пла́чу ся́ду

C.
Plur. Imp.

идйте

пишйте

спдйте

спйте

кри́кните

бу́дьте [buts]

пла́чьте [plačt $t \varepsilon$ ]

ся́дьте [sa $t \varepsilon$ ]

д'‘'лайте

кро́йте

сто́йте 
The endings of the imperative are, regardless of the class of conjugation:

$$
\begin{array}{ll}
\text { Sing. } & \text { и (ь-й) } \\
\text { Plur. } & \text { ите (ьте-йте) }
\end{array}
$$

The full ending, и, ите, is weakened:

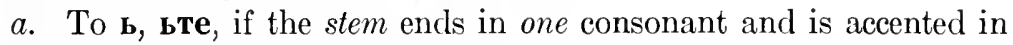
the 1st sing.: бу́ду-будь, бу́дьте. .

$b$. Tо й, йте, if the personal endings are preceded by a vowel:

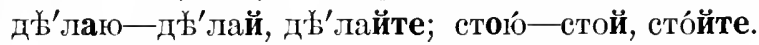

Consequently, it is preserved in full $(a)$ if the stem ends in two consonants, regardless of the accent (кри́кну-кри́кни, кри́кните), (b) if it ends in one consonant and the ending of the 1st sing. is accented (пди́-иди́, иди́те).

The final consonant of the stem is the same as.in the $3 \mathrm{~d}$ plur., e.g., мета́ть-ме́чутъ: мечи́, мечи́те; води́ть-вожу́, во́дятъ: води́.The accent is generally the same as in the 1st sing.

There are very few irregular forms, e.g., пाть-пей, пе́йте; лечь-лягъ, ля́гте; Ł'хать一по'ьзжа́й, пођзжа́йте.

56. The Infinitive.-The regular ending is ать in the First Vocalic Conjugation and ить in the Second Conjugation. The following is not an explanation, but a mere statement of facts:

I A. Most verbs in ую, уешь have infinitives in овать: здра́вствую - здра́вствовать; compare 48.--Даю́ give, стаю́ become, have the infinitives дава́ть, става́ть.-Other types are: пьо-пить, кро́ю-

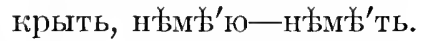

I B. Many infinitives of this class end in ать: писа́ть, каза́ть, пла́кать, мета́ть, чеса́ть, звать, слать, брать. Other types are:

a. -ти without consonant change: несу́-нести́, везу́-везти́, иду́- - дтй ог итти́.

b. -ть or -ти with change of д, т to c: паду́-пасть, кладу́класть, ся́ду-състь, веду́-вести́.

c. г-ть and к-ть change to чь: могу́-мочь, влеку́-влечь, теку́-течь, ля́гу-лечь.

II. Many verbs of the second conjugation have infinitives in $\mathbf{6} \mathbf{T b}$, others, especially those with stems in palatal sibilants, have infinitives

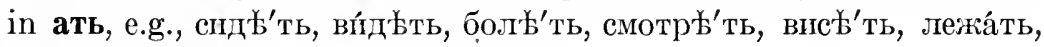
держа́ть, сль́шать, крича́ть, спать.

Anomalous:

Быть be (есть is, бу́деть will be); ‘'хать ride (官ду); бсть eat (Łuъ, 59h). 
1. Form the imperatives of all verbs in the text.

2. Arrange all verbs that have occurred in this and former texts according to their infinitives.

3. In the general vocabulary you will find that many verbs have two infinitives with more or less different meanings, e.g., броса́тьбpócuть. Add to the verbs arranged for Exercise 2, above, their second infinitive, if the difference between the two forms is in the ending, and not in a prefix. The explanation will be given later.-Keep this list for reference and additions.

\section{XLIX}

\section{СОРОКЂ ДЕВЯТЫЙ УРОКЬ}

57. The Attributive Comparative:

\begin{tabular}{|c|c|c|}
\hline Positive & $\begin{array}{l}\text { Predicative } \\
\text { Comparative }\end{array}$ & $\begin{array}{c}\text { Attributive } \\
\text { Comparative }\end{array}$ \\
\hline $\begin{array}{l}\text { би́стрый } \\
\text { ти́хій }\end{array}$ & $\begin{array}{l}\text { быстрғ'е } \\
\text { ти́ше }\end{array}$ & $\begin{array}{l}\text { быстр'‘' шій, ая, еe } \\
\text { тиша́й шій }\end{array}$ \\
\hline высо́кій & ви́іше (ви́ссше) & высоча́й шій or вы́сс шій \\
\hline коро́ткій & коро́че & крат ча́й шій \\
\hline ста́рый & cтáp ше & ста́p шій \\
\hline молодо́ї & моло́же & мла́д шій \\
\hline xоро́шій & лу́ч ше & лу́ч шій \\
\hline ма́лый & ме́нь ше & ме́нь шій \\
\hline бо́льшо́й & бо́льше & бо́ль шій. \\
\hline
\end{tabular}

1. The attributive comparative is formed by changing the ending of the predicative comparative, ‘e, to Һй шій, and е (ше) to ай шій or шій. But there are many irregular forms, which must be learned by observation.

2. There is no sharp distinction between the comparative and superlative; мoй ста́ршій братъ, моя́ ста́ршая сестра́ may mean my older brother (sister) or my oldest brother (sister). However, the forms in Łйшій and айшій have nearly always superlative meaning.

3. The comparative is often expressed by бо́лte with the positive: Это бо́лье граси́вый домъ This is the prettier house. The superlative is generally circumseribed by са́мый ( $\$ 23$ ) either with the positive or the comparative: Это са́мый краси́вый домъ This is the prettiest house; онъ са́мый ста́ршій челов'ъ'къ в'ъ го́родъ $\mathrm{He}$ is the oldest man in town.

A few adjectives form their superlative by prefixing наи- to the comparative: нанлу́ чшій best, напме́ньшій smallest. 


\section{Possessive Adjectives:}

1. Это Петро́въ домъ.-Онъ живётъ въ Петро́вомъ до́мъ.

Adjectives denoting possession or connection are derived from names of persons by replacing the ending of the gen. sing. by:

овъ, ова, ово for the gen. sing. in -a,

евъ, ева, ево for the gen. sing. in -я,

инъ, ІІна, ино for the gen. sing. in -ы, -Іг.

The accent is on the same syllable as in the genitive, e.g., ПётртПетра́-Петро́въ, Ива́нъ-Ива́на-Ива́новъ, Андре́ї-Андре́яАндре́евъ, Илья́-Ильи́-Ильи́нъ.

For declension, see 126.

These possessive adjectives are of special importance because they constitute a very large number of Russian family names and names of places.-A woman's surname appears in the feminine form, e.g., Па́вловъ-Па́влова, Улья́новъУлья́нова, Ива́новъ-Ива́нова, Турге́невъ-Турге́нева.

2. Patronymics (names of persons derived from the father's name, like Johnson, Anderson, Pearson) are formed from such possessive adjectives by changing овъ, евъ, инъ to овичъ, евичъ, ичъ in the case of men, and to овна, евна, ична in the case of women. Russians address one another not by their surnames, but by their first names (иям) and patronymies (оте́чество), е.g., Ива́нъ Петрб́внчъ (surname —фами́лія-, say, Іа́вловъ) = Ivan Pavloff, the son of Peter (Pavloff); Елизаве́та Петро́вна (Па́влова); Влади́миръ Ильи́чъ (Улья́новъ-Lenin's real name).

3. Of names of animals and a few other nouns are derived adjectives in ій, ья, ье (declension like тре́тій, $\Upsilon 26$ ), e.g., ры́ба fish-ры́бій (ры́бын [тыbji] глаза́ fish eyes)

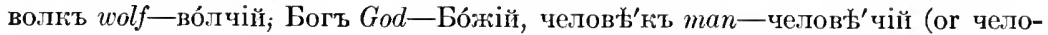
в'ъ'ческій) human.

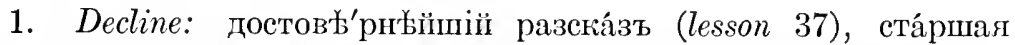

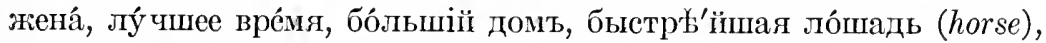
мла́дшее дитя́.

2. Form the possessive adjectives and patronymics of the following names: Алексъ’ї, Алекса́ндръ, Ники́та, Сергъ'йї, Васи́лій (gen. Васи́лья).

3. Review the text until you can tell the story fluently (not necessarily word by word).

$\mathrm{L}$

\section{ПЯТИДЕСЯТЫЙ УРОКЬ}

\section{Вопро́сы}

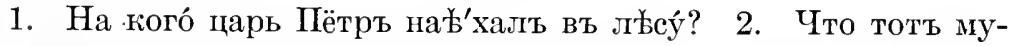
жи́къ дъ‘'лаетъ? 3. Что царь говори́тъ? 4. Что мужи́къ отвظчи́етъ? 5. Велика́ ли у мужнка́ семья́? 6. Ско́лько сынове́й 
у него́? Ско́лько дочере́й? 7. На ско́лько частёй мужи́къ де́ньги кладётъ? 8. Какі'я э́ти три ча́сти? 9. Что царь не понима́етъ? 10. Какъ мужи́къ долгъ пла́тить? 11. Кому́ онъ де́ньги въ долгъ даёть? 12. Каки́мъ образомъ онъ де́ньги въ во́ду ме́четъ? 13. Куда́ мужи́къ до́лженъ царя́ вести́? 14. Почему́ онъ до́лженъ его́ вести́? 15. Какъ мужи́къ объясня́етъ царю́ доро́гу? 16. Понима́етъ ли царь э́то обълсне́ніе? 17. Почемý мужи́къ не хо́четъ вести́ царя́? 18. Что царь обњща́етъ

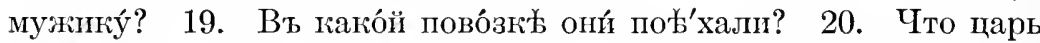

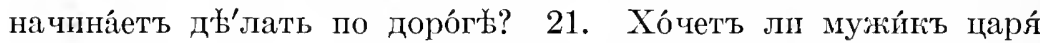
посмотры'ть? 22. Что царь ему́ говори́тъ? 23. Что бу́детъ

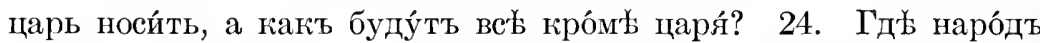

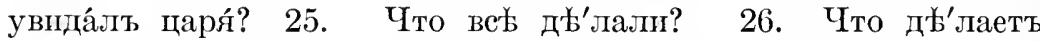
мужи́къ? 27. Что онъ спра́шиваетъ у царя́? 28. Что Пётръ Алексъъ'евичъ ему́ говори́тъ?

\section{TEXT XII}

\section{Счастли́вый человъкъ}

Оди́нъ царь си́льно забол'ъ่'лъ. Онъ созва́лъ мудрецо́въ I

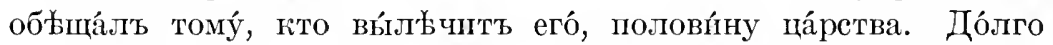
никто́ изъ нихъ не могъ приду́мать никако́го сре́дства. Наконе́цъ оди́нъ изъ мудрецо́въ говори́тъ: “На́до отыска́ть вполнбъ’ счастли́ваго человъ́'ка, снять съ него́ руба́ху п нады́'ть её на царя́, и

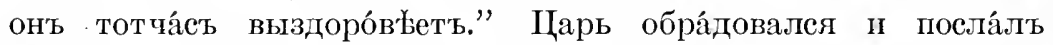
иска́ть счастли́ваго человъ'ка. До́лго пска́ли ца́рскіе слуги́ по всему́ ца́рству, но счастли́ваго челов'ъ'ка не могли́ найти́. Оди́нъ бога́тъ, но нездоро́въ, друго́й здоро́въ, но бъ'денъ, а кто здоро́въ и бога́тъ, у того́ дъъ'ти не хороши́-вся́кій чъмъ-нщбу́дь недово́ленъ. Разъ по́здно ве́черомъ идётъ ца́рскій сынъ со слуго́й ми́мо избб́ и сль́шетъ какъ кто-то говори́тъ: "Вотъ, сла́ва Бо́гу, нарабо́тался, наъъ'лся и спать лягу́; чего́ ещё ну́жно? Я вполнъъ' дово́ленъ и сча́стливъ." Обра́довался ца́рскій сынъ, что наконе́цъ нашёль

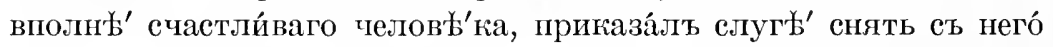
руба́ху и заплати́ть, ско́лько спро́ситъ. Слуга́ вошёлъ въ нзо̃у́, но не ви́несъ руба́хи, потому́ что у счастли́ваго человъ́'ка руба́хи не́ было. 


\section{LI}

\section{ПЯТЬДЕСЯТЪ ПЕРВЫЙ УРОКЂ}

Заболњ'ль: Боль'ть be sick, забол'ъ'ть fall sick; за- often denotes transition.

Вйльчить: Russian uses the indicative in indirect discourse; this form has future meaning: to the one who would cure him.

Никто́ не могъ приду́мать никако́го сре́дства: (1) After negative verbs the direct object stands in the genitive, compare Lesson 46, Note to доро́ги не найду́.(2) In negative sentences all indefinite pronouns and adverbs must appear in their negative form, i.e., with the prefix ни-, е.g., Никто́ не зна́етъ его́ Nobody knows him, Онъ никогда́ не рабо́таетъ He never works. - The negative particle не, however, must accompany the verb nevertheless.

Отыска́ть is composed of отъ and иска́ть; ъ and и yield ы in composition.

Бога́тый is generally pronounced [baratij]].

У счастли́ваго челов'́⿴囗ка руба́хи не́ было: Russian prefers this impersonal construction, with the logical subject (or object) in the genitive, where English would use the verb be or have, e.g., Его́ сего́дня нытъ (is not) до́ма $H e$ is not at home today. Notice the accent: [nвbыlo].

New Verbs:

I A-объща́ть, обра́доваться, приказа́ть, заболь'тьт.

I В-созва́ть (-зову́, -зовёшь), снять (сниму́, снимёшь), надъ́⿱宀'ь (-де'

мочь (могу́, мо́жешь), лечь (ля́гу, ля́жешь), иска́ть (пщу́, и́щешь), посла́ть (-шлю́, - шлёшь);

II — ви́лььчить, сль́шать; проси́ть (прошу́, про́сишь).

\section{ПЯТЬДЕСЯТЪ ВТОРОЙ УРОКЪ}

\section{Irregular Presents:}

a. Vowel Insertion.

звать call-зову́, зовёшь

брать $t a k e$-беру, берёшь

драть tear-деру́, дерёшь.

b. Vowel Omission.

жечь burn-жгу, жжёшь

тере́ть $r u b-т р у$, трёшь

-мере́ть die--мpу, -мрёшь.

c. Vowel Change.

лечь lie down一ля́гу, ля́жіешь

състь sit down-ся́ду, ся́дешь

крыть cover-кро́ю, кро́ешь

мыть wash-мо́ю, мо́ешь

пить drink-пью, пьёшь

брить shave-брғ'ю, брғ'ешь 
d. Nasal Insertion.

стать become-ста́ну, ста́нешь

нача́ть begin-начни́, начнёшь

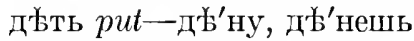

снять take off-снгмý, сни́мешь

поня́ть understand-поймý, поймёшь.

e. Verbs in -нуть.

Inchoative Verbs.

со́хнуть become dry-cóхну, со́хнешь

Verbs denoting an isolated action ('semelfactive verbs')

кри́кнуть cry out-кри́кну, кри́кннешь

тро́нуть touch-тро́ну, тро́нешь.

$f$. Insertion of в.

жнть live一зинви́, живёшь

плыть swim, float-плыву́, плывёшь.

g. Mixed Conjugation.

бъжа́ть run-бъгу́, бъжи́нь, бұжйть, бъжймъ, бъжи́те, бъгу́ть

хоть'ть want-хочу́, хо́чешь, хо́четъ, хотймъ, хоти́те, хот и́тъ.

h. Anomalous Verbs.

\begin{tabular}{|c|c|c|}
\hline быть be & дать give & Њсть $e a t$ \\
\hline & дамъ & bMъ \\
\hline & дашь & bшь \\
\hline есть & дасть & Һсть \\
\hline & дади́мм & Ђди́мъ \\
\hline & дади́тте & 'Фди́те \\
\hline суть & даду́ть & Фдя́тъ \\
\hline Imper. будь & даїі & бшпь. \\
\hline
\end{tabular}

1. Conjugate the present and imperative of all verbs in Text XII.

2. Change to the negative form: Мудре́цъ найдёть сре́дство.Ца́рскій̆ сынъ нашёлъ пзбу́.—Я понпма́ю э́то объясне́ніе.

3. Decline: Ца́рскій сынъ, Бо́жья по́мощь, Петро́въ домъ, Алекса́ндръ Па́вловичъ Ива́новъ, Екатери́на Андре́евна Па́влова. 


\section{LIII}

\section{ПЯТЬДЕСЯТЬ ТРЕТІЙ УРОКЬ}

\section{The Past Tense:}

\section{Compare:}

Text VIII A, погри́лт; B, былъ.

Text X A, спра́шиваль; В, пріъ'халь.

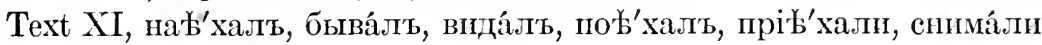
сталть, ё'лиг.

Text XII, созва́лъ, оббща́лъ, обра́довалъ, посла́лъ, иска́ли, приказа́ли, бю́ло, могъ, могли́, нашёлъ, вошёлъ, ви́несъ.

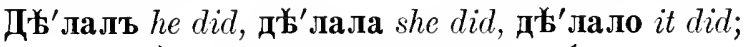

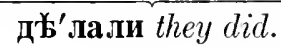

\section{A. Formation.}

1. Verbs with infinitives in ть change this to лъ (ла, ло; ліІ).

2. If the infinitive ends in чь, зти, сти, зть, сть, the masculine form omits the л: мочь-могь (могла́, могло́, моглиí); везти́вёзъ (везла́, везло́, везли́); нести́-нёсъ (несла́, несло́, несли́).

3. Verbs with stems in д or $\mathrm{T}$ and infinitives in -сть, -сти omit the д or т in all forms of the past: вести́-вёлъ, вела́, вело́, вели́; пасть

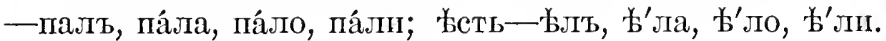

\section{B. INFLECTION.}

The past tense is not a conjugated form, like the present, but a declined verbal adjective. It has the endings of the predicative adjective, except that the plural of all three genders ends in $\mathbf{n}$ instead of br:

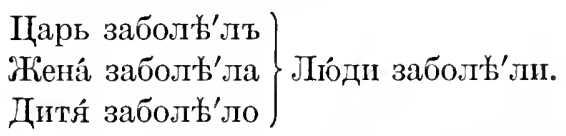

ACCent. 1. The past tense of a verb with a monosyllabic infinitive either has the accent in all forms on the stem, or the ending is accented in the feminine only, or all endings are accented:

знать-зналъ, зна́ла, зна́ло, зна́ли

быть-быль, была́, бйло, би́ли

мочь-могъ, могла́, могло́, могли́.

In the general vocabulary the accent is indicated whenever it is not stationary (i.e., it is not indicated in the case of зналъ, but in the case of былъ and могъ).

2. If the infinitive has more than one syllable, the past tense has the same accent as the infinitive (in the case of infinitives in -тí the accent rests on the last syllable). рабо́тать-рабо́талъ, рабо́тала, рабб́тало, рабо́тали нести́-нёсъ, несла́, несло́, несли́. 
1. Change all past tenses in the text to the present tense; give the four

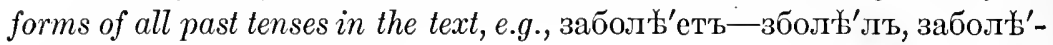
ла, заболх'ло, забол'х'ли.

2. Change all present forms in Text XI to the four forms of the past.

3. Form the past tense (four forms) of all verbs listed in $\mathbf{4 9}$ and $\mathbf{5 4 .}$

\section{LIV}

\section{ПЯТЬДЕСЯТЬ ЧЕТВЕРТЫЙ УРОКЪ}

\section{Вопросы}

1. О комъ разска́зывается въ э́томъ те́кст Ł̊? 2. Что случйлось съ царёмъ? 3. Что онъ дъ'лалъ что́бы ви́ль'читься? 4. Что онъ оббща́лъ тому́, кто ви́лб̌́читъ его́? 5. Како́е сре́дство на-

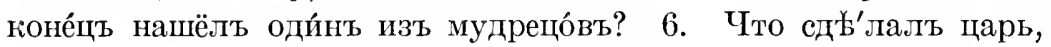
что́бы найти́ вполнь́⿱㇒冋 с счастли́ваго человЊ'ка? 7. Кто иска́лъ э́того челов '́t'ка? 8. Почемý они́ не могли́ найти́ ни одного́

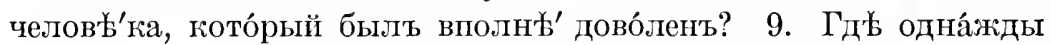
гуля́ль ца́рскій сын'ъ? 10. Съ к'ڤ̆мъ гуля́лъ онъ? 11. Что онъ сль́шаль? 12. Почему́ царскій сынъ обра́довался? 13. Что

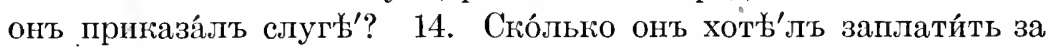

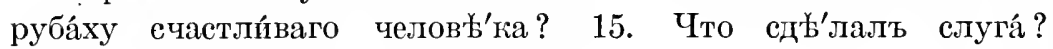
16. Почему́ онъ не ви́несъ руба́хи?

\section{TEXT XIII}

The grammatical material has now been presented to such an extent that supplementary reading can be taken up with benefit. Harper's Russian Reader (The Chicago University Press) is recommended for that purpose. Of course, the grammatical work must be continued at the same time.

The following text is taken from Harper's Reader.

\section{Бълка и волкъ}

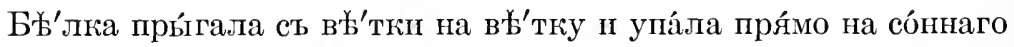

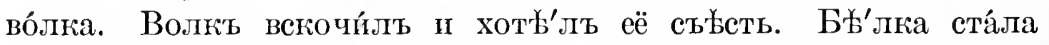
проси́ть: “Пусти́ меня́!" Волкъ сказа́лъ: “Хорошо́, я пущу́ тебя́, то́лько ты скажи́ мнћ̆, отчего́ вы, бъ'лки, такъ ве́селы. Мн’ъ всегда́ ску́чно, а на васъ смо́тришь, вы тамъ вверху́ всё пгра́ете и при́гаете." БЪъ’лка сказа́ла: "Пусти́ меня́ пре́жде на де́рево, я отту́да тебъł' скажі́, а то я бою́сь тебя́.” Волкъ пуети́лъ, а бъ’лка ушла́ на де́рево и отту́да сказа́ла: “Теб̋ł' оттого́ ску́чно, что ты золъ. Тебъ' злость се́рдце жжжётъ. А мы ве́селы оттого́, что мы добрь́ и никому́ зла не дъ’'лаемъ." 


\section{LV}

\section{ПЯТЬДЕСЯТЬ ПЯТЫЙ УРОКЬ}

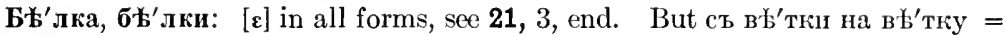
[s vetki na vetku].

Съъсть and състь are often pronounced alike, but in careful pronunciation the former has a more distinct palatal glide: $\left[s^{6} \mathbf{e} s t^{6}-s \mathbf{e s t}\right]$.

Скучно = [skušno].

Жжёть: жжж does not noticeably differ from ж.

\section{LVI}

\section{ПЯТЬДЕСЯТЬ ШЕСТОЙ УРОКЬ}

\section{The Aspects:}

A

Б'`лка прьггала = was in the act of playing.

Волкь хоть'ль её съвсть $=$ had

the desire to devour it.
$\mathrm{B}$

Бъ’лка упа́ла $=$ fell down $($ in a moment).

Волкъ скочи́лъ $=$ jumped up.

Compare:

\begin{tabular}{lllrc}
\multicolumn{1}{c}{ English } & \multicolumn{1}{c}{ French } & \multicolumn{1}{c}{ Latin } & Greek & \multicolumn{1}{c}{ Russian } \\
A-he was writing & il écrivait & scribebat & '́ $\gamma \rho \alpha \phi \epsilon$ & онъ пнса́ль \\
B-he wrote (down) & il écrit & scripsit & є́ $\gamma \rho \alpha \psi \epsilon$ & онъ написа́лъ
\end{tabular}

In many languages the action of the verb can be conceived either as uncompleted (of uncertain duration) or as completed (or momentary). This is the basic difference between simple and 'progressive' forms in English, imparfait and passé défini in French, imperfect and perfect in Latin, and imperfect and aorist in Greek.

In Russian, as in all Slavic languages, this difference constitutes an essential feature of the verb system. It is not limited to the past, as in French and Latin, but spreads over the whole conjugation. To an extent, this is the case in English too: to be writing-I am writing $-I$ was writing. But while English uses the same means for all verbs whose meaning permits this construction, Russian uses different forms, often with different shades of meaning. With nearly every verb two conjugations run side by side-just as if there were in Greek, for instance, two complete verbal systems with the stems $\gamma \rho a \phi$ - and $\gamma \rho a \psi$ -

The various ways of action-momentary, continuous, repeated, customary, etc.-are called aspects in Slavic grammar. We distinguish chiefly the perfective aspect, denoting completed or momentary action, and the imperfective aspect, denoting progressing or repeated action; the latter is often called the durative aspect. 
1. State the aspect of each verb in Texts $X$ and $X I$ and substitute the corresponding form of the other aspect; consult the vocabulary for the forms. For the time being, do not attempt to explain the difference in meaning between the two forms.

E.g.: мужийъ везёть imperfective一повезётъ, perfective; друго́й идётъ, imperfective-пойдётъ, perfective.

2. Change all preterit forms in Text XI to the $3 d$ sing. pres. of both aspects, e.g., нағ'халь-навзжа́еть, на'ь'деть.

3. Царь заболов'ль the Tsar fell sick; царь боль'ль he was sick. Онъ созва́ль he summoned; онъ сзыва́ль he was occupied in calling them together.

(a) State the aspect and substitute the corresponding form of the other aspect for the following forms: объща́лъ, прпду́малъ, отыска́лъ, обра́довался, посла́лъ, иска́ли, нарабо́тался, нағ'лся, нашёлъ, приказа́лъ, вопеёлъ, ви́несъ.

(b) Explain the difference between each two forms, as shown above for боль'лъ-забооль'лъ, сзыва́лъ-созва́лъ. Remember: You are not to 'translate' the aspects-that is rarely possible-, but to describe the difference in the situation.

\section{LVII}

\section{ІІЯТЬДЕСЯТ'Ь СЕДЬМОЙ УРОКЪ}

\section{Simple and Compound Verbs:}

Imperfective: учи́т

Perfective:

$$
\begin{aligned}
& \text { научи́ть послу́шать ви́купать } \\
& \text { н为前'ть }
\end{aligned}
$$

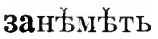

$$
\begin{aligned}
& \text { выть } \\
& \text { взвыть } \\
& \text { ви́д方ть } \\
& \text { уви́д官ть. }
\end{aligned}
$$

храни́ть

сохрани́ть

The most frequent way of forming the two principal aspects is by contrasting the verb with a prefix to the simple verb. The simple verb expresses the imperfective, the compound verb the perfective aspect. A given imperfective verb takes a definite prefix to make it perfective, and in that particular compound the prefix virtually loses its proper meaning; it is merely a grammatical device of expressing the perfective aspect. It is necessary in every case to know what prefix must be used, for all prefixes but that one change the meaning of the verb aside from its aspect. Thus, the prefix съ- c- must be used with дъ'лать, жечь, пгра́ть, etc., to make them perfective (сдь'лать act, сжечь burn up, сыграть = сь +пгра́ть make a play); if used with a verb that calls for a different prefix to make it perfective, it expresses connection or separation, е.g., состои́ть consist, снима́ть take off. 
By far the most frequent of all prefixes is no. It is entirely colorless, aside from making the verrb perfective.

Of the 125 different verbs that have occurred in the texts, 70 form their perfective aspect by means of prefixes, and with more than 30 of these the prefix no must be used, e.g., люби́ть-полюби́ть (take a liking), крыть-покри́ть (cover up).

The other prefixes generally retain some trace of their original meaning, although it is not always clearly apparent. Thus съ- (с-, со-) in сд屯'лать, сохрани́ть, слома́ть has a shade of the meaning of completeness, either of connection or of separa-

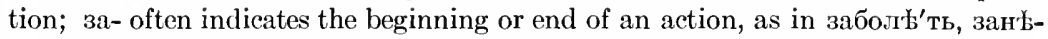
мъ'ть, закрыва́ть; compare 67. But one should not lay too much stress upon these slight variations of meaning, but rather keep in mind that д храни́ть-сохрани́ть, плати́ть-заплати́ть represent contrasts similar to that between the French imparfait and passé défini, or the Greek imperfect and aorist.

To each infinitive listed with Exercise 4, Lesson 34, add the infinitive of the other aspect; arrange those pairs of verbs that differ by prefix only, according to those prefixes (making, e.g., one list of no-perfectives, one of sa-perfectives, etc.).

\section{LVIII}

\section{ПЯТЬДЕСЯТЬ ВОСЬМОЙ УРОКЬ}

\section{Вопросы}

1. Какъ загла́віе э́того те́кста? 2. Что бњ'лка ды'лала? 3. На кого́ она́ упа́ла? 4. Что бъ'лка ста́ла дъ'่'лать? 7. Что бъ'лка должна́ была́ сказа́ть во́лку? 8. Комý всегда́ ску́ чно?

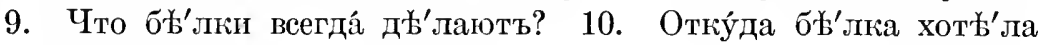

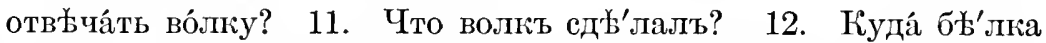
ушла́? 13. Отчего́ во́лку всегда́ ску́чно? 14. Что емý се́рдце жжётъ? 15. Отчего́ бъ'лки всегда́ ве́селы?

\section{TEXT XIV}

\section{Волкъ и котъ}

Волкъ и́зъ-ль̆су в’ъ дере́вню забъжжа́лъ,

Не въ го́сти, но живо́тъ спаса́я;

За шку́ру онъ свою́ дрожа́лъ:

Охо́тники за нимъ и го́нчихъ ста́я.

Онъ радъ бы въ пе́рвыя тутъ шмь́гнуть ворота́,

Да то лишь го́ре,

Что всъ воро́та на запо́pł.

Вотъ, ви́дитъ волкъ мой на забо́ръ

Кота́. 
И мо́литъ: “Ва́сенька, мой другъ! скажи́ скоръъ'е,

Кто здъсь изъ мужико́въ добрғъ'е,

Что́бы укрыть меня́ отъ злыхъ мои́хъ враго́въ?

Ты сль́шишь лай соба́къ и стра́шный звукъ рого́въ!

ВҺъдь э́то всё за мной!"

—“Проси́ скорб'̆ї Степа́на:

Мужи́къ предоборый онъ”-ккоть Ва́ська говори́тъ.

—“То такъ; да у него́ я ободра́лъ бара́на."

—“Ну, попыта́йся-жъ у Демья́на!"

— "Бою́сь, что на меня́ и онъ серди́тъ:

Я у него́ унёсъ козлёнка."

—“Бъги́-жъ, вонъ тамъ живёть Трофи́мъ."

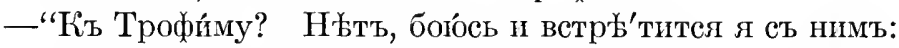

Онъ на меня́ съ весни́ грызётся за ягнёнка!"

—“Ну, пло́хо-жъъ!. . . . . Но аво́сь теби́ укро́етъ Климъ!"

—“"Охъ, Ва́ся, у него́ заръъ’залъ я телёнка!”

—“"Что ви́жу, кумъ! Ты всъмъ въ дере́вн务 насоли́лъ!”

Сказа́лть тутъ Ва́ська во́лку:

“Каку́ю-жъь ты себъł' защи́ту здъъсь сули́лъ?

НҺтъ, въ на́шихъ мужика́хъ не сто́лько ма́ло то́лку,

Чтобъ на свою́ бъдду́ тебя́ спасли́ они́,

И пра́вы; саиъ себя́ вини́:

Что ты посъ'ялъ, то и жни!"

Крыловъ.

\section{LIX}

\section{ПЯТЬДЕСЯТЬ ДЕВЯТЫЙ УРОКЬ}

Изъ-льсу: Compare ча́ю, cáxapy, Text VI, and $\uparrow 14,4$. In closely connected phrases the preposition is often accented (the hyphen is not always used).

Спаса́я: Uninflected present participle (so-called gerund) of спаса́ть-in order to save his life.

Свою́ belongs to IIкýpy. Poetic word order has a certain amount of freedom.

Ворота, used in the plural form only, may have the accent on the second or the last syllable: воро́та, ворота́.

Ва́сья (Ва́ська, Ва́сенька) are diminutive (endearing) forms of Ва́сплій.

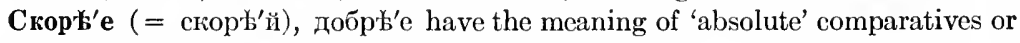
superlatives: very quickly, very good (as good as......).

В'ды in this passage comes near to having its primary meaning; it is originally an imperative of an (obsolete) verb meaning to know.

Предобрый: The prefix пре-forms absolute superlatives: very good.

Вонъ тамъ: Over yonder.

Съ веснй: Съ with the genitive of expressions of time means since. 
Nouns in -ёнокъ: Such nouns denote young animate beings, like ребёнокъ boy, котёнокъ kitten, телёнокъ, козлёнокт, ягнёнокъ; they are masculine in the singular and neuter in the plural. Declension: ребёнокъ, ребёнка.....; ребя́та, ребя́тъ, ребя́тамъ......

The Subjunctive. There is no real subjunctive form in Russian, but the particle бы (originally a preterit form of the verb быть $b e$ ) before or after the past participle has conditional force: Я (ты, онъ, мы, вы, они́) б́то сдъ'лаль (-и) бы I should do that, should have done that.-Чтббы оr чтобъ in order that, so that is followed by the infinitive if the subordinate clause has the same subject as the principal clause, but by the past participle if the subjects are different: Кто добр'ь'е, чтббы укри́ть меня Who is so kind-hearted that he would hide me? въ на́шихъ мужика́хъ не стб́лько ма́ло то́лку, чтобъ тебя́ спасли́ there is not so little sense in our peasants that they would save you. Occasionally бы is found with a predicative adjective instead of a past form: Онъ радъ бы he would be glad to......

Perfective Compounds in this Text:

The verbs гнать, жіть,- моли́ть(ся), пыта́ть, сули́ть, form their perfective forms with по-; гри́зться, серди́ться with раз-; жать, with съ-; внни́ть, with об̄-: погна́ть, разгри́ зться, сжать, обвини́ть, еtс.

\section{LX}

\section{ІІІСТИДЕСЯТЫЙ УРОКЂ}

\section{Stem Variation:}

\section{A. Compounds.}

Дь'лать requires the prefix c-, писа́ть the prefix на-, крыть the prefix по- for the purpose of perfectivation. These prefixes do not change the meanings of these verbs, but lose their own, usual meaning.

But if the same verbs are compounded with any other prefixes, they change their

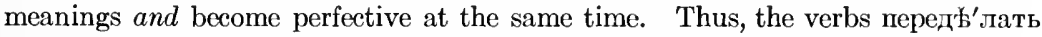
make over, alter, подписа́ть subscribe, откри́ть uncover, open, are perfective and have specialized meanings, so that the prefix serves a double purpose.

To form the imperfective aspect of сди'лать we simply omit the prefix. In the case of передь'лать, подписа́ть, откри́ть this cannot be done without changing the meaning of the verb. Instead, the stem is changed in one of the following ways:

1. By Stem Suffix:

a. Monosyllabic stems of I A add Ba to the stem; thus are derived the following

Imperfectives узнава́ть-узнаю́, -ёшьь открыва́ть-открыва́ю забыва́ть-забыва́ю одъвва́ть-одъвва́ю from Perfectives:

(48) узна́ть-узна́ю, -ешь откри́ть-откро́ю, -ешь заби́ть-забу́ду, -ешь

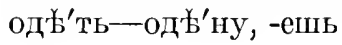


b. Verbs with polysyllabic infinitives in ать, ять, Һть, also add ва, but change the preceding vowel to ы оr и:

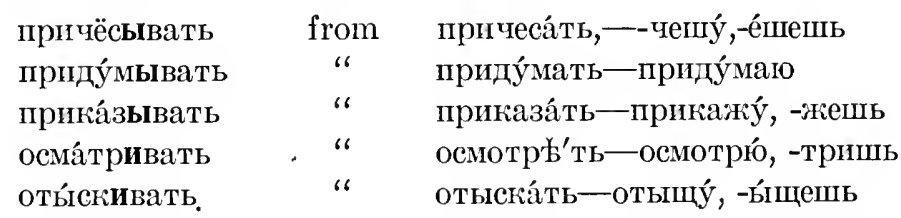

Note.--Verbs in -вать are primarily 'Iteratives' or 'Frequentatives', i.e., verbs that denote repeated action, like Latin iactitare 'throw about'; but in modern Russian this meaning is rarely preserved (быть be-быва́ть be often, frequent). Nearly always these formations have merely the purpose of forming the imperfective aspect of compound verbs.

c. Verbs with infinitives in зть (зти), сть (сти), and чь add $\mathbf{a}, \mathbf{g}$ to the stem; those in ить and нуть change this infinitive ending to ять (ать), rarely to ивать:

\begin{tabular}{|c|c|c|}
\hline сьь'дать, -даю & from & сьъсть, сьбмъ $(59 h)$ \\
\hline упада́ть, -да́ & & упасть, -ду́, -дёпгь \\
\hline ь, -я́ю & " & попра́вить, -влю, -вишь \\
\hline І Я́ть - -Ля́ю & 6 & пи́ть, -лю́, -лпшь \\
\hline нау ча́ть, -ча́ю̊ & & научи́ть, -чу́, -чишь \\
\hline отв б̆ча́ть, -ча́ю & 66 & отвъ'тить, -чу, -тишь \\
\hline наса́ливать, -ва & 6 & насоли́ть, -лю́, -ли́шь \\
\hline & " & отдохну́ть, -ну́, -нёшь \\
\hline
\end{tabular}

2. By Change within the Stem:

Verbs of class I B with two successive consonants in the stem (either in the infinitive, or in the present, or in both forms) insert $\mathbf{и}$ (sometimes ы) between them:

$\begin{array}{lcl}\text { собира́ть, -ра́ю } & \text { from } & \text { собра́ть, -берý, -рёшь } \\ \text { умира́ть, -ра́ю } & \text { “ } & \text { умере́ть, умру́, умрёшь } \\ \text { обдира́ть, -ра́ю } & \text { “ } & \text { ободра́ть, -дру́, -дрёшь } \\ \text { вызыва́ть, -ва́ю } & \text { “ } & \text { ви́звать, -зову, -зовешь } \\ \text { посылать, -ла́ю } & \text { “ } & \text { посла́ть, -шлю́,-шлёшь }\end{array}$

Nasal Stems. The infinitive of stems of I B with final nasal ends in ять (ать) instead of н-ть, м-ть, just as the stem имен- has the nom. sing. и́мя; е.g., на-чну, на-чнёшь-inf. на-ча-ть begin; жну, жнёшь-жать harvest; воз-ьмý, возь-мёшь -вз-ять take (compare $59 \mathrm{~d}$ ). In the imperfective compounds of these verbs the nasal is retained and in inserted before it: 


$$
\begin{array}{lcc}
\text { на-чнн-ать, -а́ю } & \text { from } & \text { на-ча́ть, на-чну́, -чнёпь } \\
\text { за-н-им-ать, -а́ю } & \text { “ } & \text { за-н-я́ть, за-ймý, -ймёшь }
\end{array}
$$

The stem -ьм- (inf. -ять) take, occurring only in compounds, like занпма́ть, is an important example of this type. The perfective compounds have the form-H-ять, -ймy if the prefix ends in a vowel, but the form -н-ять, -н-имy if it ends in a consonant; the imperfective compounds have the form -н-нмать, -н-нмаю:

$$
\begin{array}{lcl}
\text { понима́ть, -нима́ю } & \text { from } & \text { поня́ть, поймý, поймёшь } \\
\text { поднима́ть, -нцма́ю } & \text { “ } & \text { подня́ть, поднцму́, -мёшь }
\end{array}
$$

Résumé: A simple, imperfective verb is made perfective by a prefix. All prefixes but one ehange the meaning of the verb at the same time. The new, perfective compound verb with specialized meaning is in turn made imperfective by stem variation, consisting in suffixation or stem vowel change. This is illustrated by the following diagram, in which the horizontal lines indieate progressing action or lasting condition, i.e., the imperfective (durative) aspect, the vertical lines-the risers in the stairway - the perfective aspect.

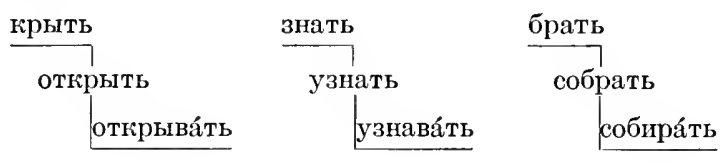

\section{B. Simple Verbs.}

A small number of verbs are perfective without a prefix. The following types occur:

1. A few monosyllabic infinitives denoting the simplest, least specialized actions; their imperfective forms have lengthened stems:

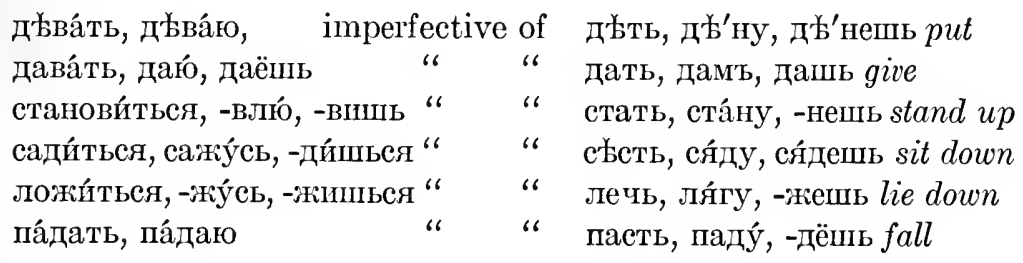

2. Verbs in ить with imperfective infinitives in ать:

$\begin{array}{llll}\text { броса́ть, -áю } & \text { imperfective of } & \text { броси́ть, бро́шу, -сишь throw } \\ \text { конча́ть, -áю } & \text { “ } & \text { “ } & \text { ко́нчить, ко́нчу, -чишь end } \\ \text { проща́ть, -áю } & \text { “ } & \text { “ } & \text { прости́ть, прощу́, -стишь for } \\ \text { пуска́ть, -áю } & \text { “ } & \text { “ } & \text { пусти́ть, пущý, -стишь release }\end{array}$


3. Verbs in нуть, denoting single action ${ }^{1}$, generally with imperfective infinitives in -ать:

крича́ть, кричу́, -чншь, imperfective of кри́кнуть cry out

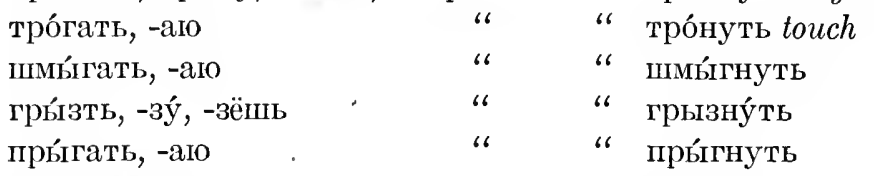

Nоте.-With some of these verbs the compound shows the same distribution of aspect as the simple verb, viz., an imperfective verb in -ать and a perfective one in ить, е.g., пропуска́ть-пропусти́ть let through; with others, the imperfective compound adds a suffix, as explained under A, e.g., одъва́ть-одъ'ть, выбра́спвватьви́бросать or ви́бросить. In a few cases the compound imperfective has the accent on the suffix while the simple imperfective accents the stem, e.g., пропада́ть, -áю, imperfective of пропа́cть get lost-simple imperfective па́дать, па́даю.

1. Continue your list of perfective compounds (compiled with Lesson 57) by adding the verbs of the same type occurring in this text (listed p. 71).

2. Arrange the imperfective compounds that have occurred in a similar list.

3. Change all past forms in the text to the present and all present forms to the past of the same aspect, e.g., забъжа́лъ-забъжа́етъ; ви́дитъвйд’ёлт.

4. Continue through all persons: Скажи́ мнъ! Укро́ї меня́! Я бою́сь во́лка.

5. Decline: Пе́рвыя воро́та́, мой врагъ, предо́брый мужи́къ, э́тотъ ягнёнокъ, ма́ленъкій козлёнокъ.

\section{LXI}

\section{ІІЕСТЬДЕСЯТЬ ПЕРВЫЙ УРОКЪ}

\section{Verbs of Single Aspect:}

1. A number of verbs form only one of the two aspects, the other one being incompatible with the meaning of the verb. Thus, the perfective aspect is not used in the case of verbs like состоя́ть consist, принадлежа́ть belong, знать know (узна́ть means begin to know, i.e., learn, find out), зна́ чить mean, сто́ить (сто́ишь, сто́ншь) cost (do not confuse this with стоя́ть, стою́, стоі́шь stand). On the other hand, the imperfective aspect is not expressed with such verbs as состоя́ться take place, полюби́ться fall in love, завладж'ть take possession, seize.

${ }^{1} \mathrm{Cp} .58 \mathrm{e}$; inchoative verbs in нуть are imperfective. 
2. With a few verbs the two aspects are taken from different stems, each of the two stems expressing only one aspect:

Imperfective

говори́ть

брать, беру́, берёшь

ілласть, кладу́, -дёшь

бить, бью, бьёшь

лови́ть, -влю́, 'вншь
Perfective

сказа́ть, -жу́, -жешь say

взять, возьму́, -мёшь take

положи́ть, -жу́, -жи́шь lay

уда́рить, -рю, ришь hit

поймáть, -мáю catch

65. Definite and Indefinite Aspect.-Certain verbs of motion have two forms for the imperfective aspect. One of them, called the definite, actual, or concrete imperfective, expresses the motion as directed to a certain place or purpose; the other, called the indefinite, potential, or abstract imperfective, describes the action as such, without reference to any definite occasion. For instance, in Text XI the sentence сведи́ мени́ means: Guide me away from this place, to some other definite place; мнб не́когда води́ть means: I have no time to act as a guide-in general. Итти́ means to be on the way to a place (Дити́ идётъ въ шко́лу The child is on his way to school), but ходи́ть means to be in the habit of going (Дитя́ хо́дитъ въ шко́лу The child goes to school, is a pupil). Such verbs are:

\section{Indefinite}

ходи́ть, хожу́, 'дишь

бъ'гать, -аю

лета́ть, -а́ю

пла́вать, -аю

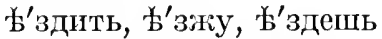

води́ть, вожу́, 'дишь

вози́ть, вожу́, 'зишь

гоня́ть, -я́ю

лома́ть, -а́ю

сажа́ть, -а́ю

носи́ть, ношу́, 'сишь

\section{Definite}

итти́, иду́, ндёшь go

бЊжа́ть, -гу́, -жґи́шь run

леть'́ь'т, -чý, -ти́шь $f y$

плыть, плыву́, -ёпь swim

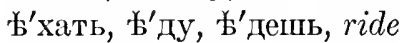

вести́, веди́, -дёшь guide

везти́, везу́, -зёшь convey

гнать, гоню́, 'нишь, chase, drive

ломи́ть, ломлю́, 'мишь break

сади́ть, -эґу́, -'дишь set, plant

нести́, несу́, -ёшь carry

To repeat it: Both forms are imperfective, but it is easily seen that, both in form and in meaning, the indefinite group shows a certain affinity with the other imperfective verbs, the definite group, with the perfective verbs. It is in keeping with this that the definite form is generally used to form the prefixal perfective without change of meaning: 


\begin{tabular}{|c|c|c|}
\hline & Imperfective & Perfective \\
\hline $\begin{array}{l}\text { Indefinite: } \\
\text { Definite: }\end{array}$ & $\left.\begin{array}{l}\text { ходи́ть } \\
\text { нтти́ }\end{array}\right\}$ & пойти́ \\
\hline $\begin{array}{l}\text { Indefinite: } \\
\text { Definite: }\end{array}$ & $\begin{array}{l}\text { вози́ть } \\
\text { везти́ }\end{array}$ & повезти́ \\
\hline
\end{tabular}

On the other hand, if the prefix specializes the meaning, the most common device is to use the definite form for the perfective, the indefinite form for the imperfective aspect:

$$
\begin{array}{cccc}
\text { Imperfective: } & \text { сносі́ть } \\
\text { " } & \text { уходи́ть } & \text { Perfective: } & \text { снести́ carry off } \\
& \text { “ } & \text { уйти́ go away }
\end{array}
$$

But there are numerous instances of different usage, which are better learned by practice.

1. Conjugate the present of сказа́ть, взять, брать, снять, класть, поня́ть, пойма́ть, понима́ть. Use each of these verbs in a sentence.

2. Locate the passages in the texts where any of the verbs listed in $\mathbf{6 5}$ have occurred; substitute the indefinite for the definite aspect, or vice versa, and explain the difference in meaning.

3. Review the text; if possible, memorize it.

\section{LXII}

\section{ІІЕСТЬДЕСЯТЪ ВТОРОЙ УРОКЬ}

\section{Вопросы}

1. Куда́ э́тотъ волкъ забłжа́лъ? 2. Почему́ онъ забъъжа́лъ въ дере́вню? 2. Что зна́читъ: “Онъ дрожа́лъ за свою́ шку́ру”? 4. Что охо́тники дълали? 5. Что волкъ радъ бы ды'лать? 6. Какови́ веъ воро́та́? 7. Кого́ волкъ ви́дитъ на забо́pł? 8. Что онъ говори́тъ къ немý? 9. Отъ кого́ волкъ ждёть защи́ты? 10. Что волкъ сль́шитъ за собо́ю? 11. Како́й мужи́књъ Степа́нъ? 12. Что волкъ ды'

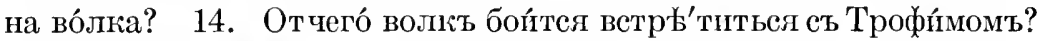
15. Отчего́ Климъ не укро́етъ во́лка? 16. Какови́ посл'ъднія слова́ кота́? 


\section{TEXT XV}

\section{Слёзы матерей}

Внима́я ýжасамъ воїни́

При ка́ждой но́вой жее́ртвъ̆ бо́я

Мнб́ жаль не дру́га, не жени́,

- Мнґ жаль не самого́ геро́я. . . .

Уви́! уть́'шится жена́,

И дру́га лу́чшій другъ забу́детъ;

Но гдъ́⿱宀-то есть душа́ одна́-

Она́ до гро́о̆а по́мнить бу́детъ.

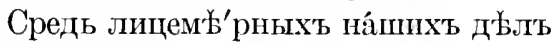

И вся́кой по́шлости и про́зы

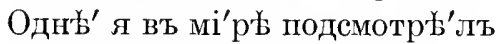

Святи́я, и́скренныя слёзы-

То слёзы бъ'дныхъ матере́ї:

Имъ не заби́ть своі́х'ъ д'九те́й, Поги́бшихъ на крова́вої ни́въ,

Как'ь не подня́ть плаку́ чей и́в

Свои́хъ пони́кнувшихъ в'ьтве́й.

Некра́совъ.

\section{LXIII}

\section{ІШЕСТЬДЕСЯТЬ ТРЕТІЙ УРОКЪ}

Внима́я у́жасамъ: Внима́ть requires a dative object; внимáя is an undeclined present participle (gerund), like бушу́я (VIII A), спаса́я (XIV).

Міръ: і еъ то́чкой $(\mathbf{1 8}, \mathbf{1})$; миръ реасе has пі двойно́е.

Имз не забыть To them it is not (given) to forget, i.e., they cannot forget; the same construction below, не подня́ть плаку́ чей і́въ...

Свои́хт вњтв'⿳⺈: Genitive object in a negative sentence; пони́кнувшихъ, active past participle, having sunk down, drooping.

New Verbs:

Perfective by Prefix:

$$
\begin{aligned}
& \text { ть'́шить-уть'шить } \\
& \text { по́мнить-вспо́мнить }
\end{aligned}
$$

$$
\begin{aligned}
& \text { ги́бнуть-поги́буть* } \\
& \text { пла́кать-запла́кать }
\end{aligned}
$$

Imperfective by Stem Variation:

$$
\begin{array}{cc}
\text { внима́ть-внять } & \text { поднима́ть-подн я́ть } \\
\text { забыва́ть-заби́ть } & \text { поника́ть-пони́кнуть * } \\
\text { подсма́тривать-подсмотрь'ть. }
\end{array}
$$

* See footnote with 63 B 3. 


\section{LXIV}

\section{. IIЕСТЬДЕСЯТЬ ЧЕТВЕРТЫЙ УРОКЬ}

\section{The Future:}

\section{Imperfective}

\section{Онá до гро́ба по́мн́ить бу́детъ.}

\section{Perfective}

\section{Ут́' шится жена́.}

1. The future tense of an imperfective verb is formed by means of the auxiliary verb бу́дy (-дешь) and the infinitive: Мать бу́детъ помннить до гро́ба $=$ all of her life she will continue to remember.

Note.-It is important to remember that this compound future is formed only from imperfective verbs.

Sometimes, especially in negative sentences, ста́ну is used instead of бу́ду.

2. The present form of a perfective verb has future meaning: ЖReнá ут'в'пится = the wife will be comforted, will be merry.

From this follows that a perfective verb cannot have a present tense. This is quite natural: A perfective verb expresses momentary action, or a momentary phase of an action; this is not likely to be described while it is actually happening Бъ'лка (у)падёть на волкка can hardly mean that the squirrel is falling down upon the wolf at the very moment the sentence is spoken; the past being expressed by a special form (упа́ла), упадёть must necessarily bave future meaning.

While not recognized by formal grammar, the same is more or less true in some other languages, notably in German; lieben 'love' is imperfective by meaning, but kommen 'come' is generally perfective; consequently, ich liebe ihn is by all means the present tense, but ich komme is usually the future.

1. Change all imperfective present forms in Text XI both to the imperfective and the perfective future, using each in a suitable sentence and explaining the difference, e.g., руббитъ-Мужи́къ бу́деть руби́ть дрова́ = Cutting wood will be his occupation; онъ нару́битъ э́то де́рево $=$ He will fell this tree.

2. Conjugate the perfective and imperfective future of мета́ть, плати́ть внима́ть, забыва́ть.

3. Memorize the poem.

TEXT XVI

\section{Два 'крестьянина и туча}

“Смотрі́-ка, братъ Анто́нъ!” сосł'ду говори́тъ крестья́нинъ Агафо́нъ, а самъ весь побльднь'ль и такъ, какъ листъ, трясётся: "Смотри́-ка, ту́ ча къ намъ несётся!"

—Тагъ что-жъ? 
—Какъ что? да градъ пойдёть и хльббъ у насъ побъётъ; всё пропадётъ; ози́мое и ярово́е; голо́дный бу́детъ годъ, а тамъ, гляди́, и моръ!

-Пусто́е, братъ, пусто́е. Како́й несёшь ты вздоръ! Не градъ, а дождь пойдёть: давно́ къ дождю́ въ̆дь па́ритъ. . Вотъ ка́плеть, ка́жется. Ужъ то-то хлЊб̆ъ попра́вить! Мы уберёмъ его́ и мно́го продади́мъ, да бра́ги навари́мъ: гуля́й и пей ужо́ зимою! Пусть дождь идётъ, я о́чень радъ!

-Ну, посмотри́, поси́плетъ градъ.

-НЊть, дождь пойдётъ.

-Градъ.

-Дождь.

-Не спорь же ты со мно́ю!

- Да что и спо́рить съ дурако́мъ!

Анто́нъ за э́то хвать сось'да кулако́мъ; тотъ въ у́хо самъ его́, и дра́ка начала́сь. Ни градъ, ни дождь ещё нейдётъ, а кровь изъ обоои́хъ ужъ льётъ. Межъ тымъ прочи́стилось-н ту́ча пронесла́ся.

\section{LXV}

\section{ІІЕСТЬДЕСЯТЬ ПЯТЫЙ УРОКЬ}

\section{NOTES}

Смотри́-ка: -ка is an emphatic particle, used frequently with the imperative, e.g., скажír-ка now, do tell.

Весь побльднъ'лъ: English would use an adverb (quite, entirely).

Такъ что-жъ Well, what about it?

Дa Why?

Tо-то: Emphatic reduplication (= э́то).

$\mathbf{y}$ жó, for yжë, frequent popular pronunciation instead of yжé.-The imperatives гуля́й, пей have the meaning of futures with indefinite subjects: We-youeverybody will make merry.

Нейдётъ: Contraction of the negative particle with пдётъ; similarly ны̆тъ $=$ не-сть.

Пусть (imperative of пуети́ть, for пусти́) or пуска́й (imperative of пуска́ть) with the third person singular or plural amounts to an imperative of the third person: пусть придётъ let him come, пусть подождётъ let him wait, пусть приду́тъ let them come.

Да что и спо́рить Well, why should I quarrel?......

Хвать кулако́мъ Crack! goes his fist upon his neighbor.

Ужъ, мъжъъ, popular abbreviations for уже́, м'ъ'жду.

Крестья́нинъ, plural крестья́не.-Masculines in -анинъ, -янинъ, denoting social standing or nationality, form their plural in -а́не, -я́не (gen. plur. -анъ, янъ), е.g., граждани́нъ citizen-гражда́не, англича́нннъ Englishman-англича́не. 
Weather:

дожғдь пдёть $i t$ is raining; снъгъ ндётъ $i t$ is snowing; градъ идётъ it hails; мо́лнія сверка́етъ it is lightning; громъ греми́ть it is thundering.

New Verbs:

Perfective by Prefix:

\begin{tabular}{|c|c|}
\hline $\begin{array}{l}\text { лить-поли́ть } \\
\text { спо́рить-поспо́рнтть } \\
\text { си́пать-поси́ппать } \\
\text { бить-поби́ть }\end{array}$ & 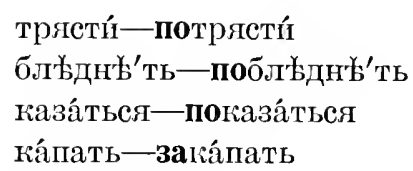 \\
\hline
\end{tabular}

Imperfective by Stem Variation:

прочища́ться-прочисти́ться убира́ть-убра́ть

пропада́ть-пропа́сть нава́ривать-навари́ть

продава́ть-прода́ть

Without Perfective Aspect: па́рить be suspended in the air, hover, hang.

Indefinite and Definite Aspect:

Imperfective проноси́ться, perfective пронести́сь.

\section{LXVI \\ ІІЕСТЬДЕСЯТЪ ІІЕСТОЙ УРОКТ}

67. Verb Prefixes: The following is neither a complete list of prefixes, nor an exhaustive statement of the meanings of any of them. A full understanding of this important part of Russian word structure can only be gained by considerable practice. But these brief hints may suggest the value of an independent analysis of compound verbs.

All verbal prefixes were originally prepositions, but the prefixes воз-, вы-, низ-, пере-, раз- are no longer used as such.

Bo3- (sometimes, especially before vowels, в3-) means up, but often also out: вздыха́ть breathe deeply, sigh, всходи́ть rise.

Вы- out: выводи́ть (ви́вести), выходи́ть (ви́йти); sometimes it denotes completion: ви́лььчтьь--Вы- is accented in perfective compounds, but unaccented in imperfective compounds.

До- up to, throughout: доъ'хать, догоня́ть overtake.

3a- originally behind, is a prefix of many different meanings; especially often it denotes action of brief duration, or the 'getting over' a thing: заходи́ть ог забъжа́ть make a call, заплати́ть make payment, забыва́ть forget, закрыва́ть close. 
На- upon: найти́ find (compare Latin invenire), надъ́⿱宀女 риt on, начина́ть begin (compare German anfangen).

Об- (о-, обо-) about: объясня́ть explain ('surround with light'), од’ъва́ться dress ('put around').

От- (оть-) from: открыва́ть uncover, open, отв屯ча́ть answer (compare German antworten).

IIo-, like German be-, is quite colorless; sometimes, however, it forms what might be called 'verb diminutives,' e.g., пожима́ть press a little, потя́гивать pull a little, draw out (gradually), почита́ть read a little.

Под- under, пред- before, при- towards, про- through, раз- apart.

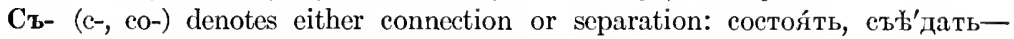
своди́ть, снима́ть.

У- away from: уходи́ть, уноси́ть, уббłжа́ть; sometimes it denotes beginning: уз̆на́ть.

1. Compare your list of compound verbs (Lesson 5\%, Exercise, and Lesson 60, Exercise 1) with these observations on prefixes and try to explain the meanings of some of the compounds.

2. Form an independent sentence with each of the verbs cited as instances in this lesson.

3. Examine all present forms in this text, state whether they have present or future meaning, and give explanation.

4. Change all present and past forms in the text to the imperfective future.

5. Decline: ста́рый крестья́нпнъ, э́тотъ бога́тыї граждани́нъ.

6. Review the text.

\section{LXVII}

\section{ШЕСТЬДЕСЯТЬ СЕДЬМОЙ УРОКЬ}

\section{Вопросы}

1. О комъ разска́зывается въ э́томъ те́ксть́ 2. Почему́ э́тоть мужи́къ трясётся какъ листъ? 3. Чего́ онъ бои́тся? 4. Что случи́тся, когда́ пойдёть градъ? 5. Како́й годъ бу́детъ въ э́томъ

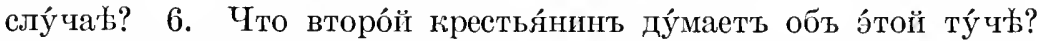
7. Какъ ему́ ка́жется пого́да? 8. Почему́ онъ жела́етъ, что́бы дождь пошёлъ? 9. Что мужики́ бу́дуть дь'ылать, е́ли бу́детъ

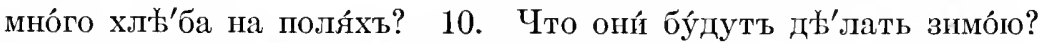
11. Чъ̆ъ пе́рвый мужи́кь называ́етъ второ́го? 12. Что Анто́нъ дъ‘' лаеть пото́мъ? 13. Что случи́лось пото́мъ? 14. Что пошёлъ,

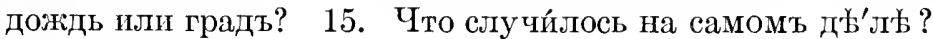




\section{TEXT XVII \\ Картинка}

осмотри́, въ нзбъ'安, мерца́я,

Св'`́тит огонёкъ.

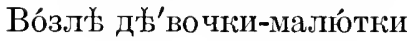

Собрался́ кружо́къ.

И съ трудо́мъ, отъ сло́ва къ сло́ву

Па́льчикомъ водя́,

По печа́тному чита́еть

Мужнчка́мъ дітя́.

Мужкички́ въ глубо́кой ду́м'์

Слу́шають, молча́ть;

Ра́зв́⿱⺊口灬 кри́кнеть кто, чтобъ ба́бы

У'няли ребя́тъ.

Да́же съ пе́чи не слю̌̀за́вшій

Мно́го, мно́го льттъ,

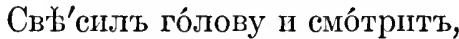

Хоть не сли́пнть, дьдъ.

Что-жъ такъ слу́шають малю́тку?

Аль ужъ такъ умна́?

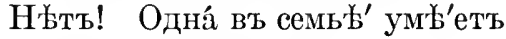

Гра́моть́ она́.

И пришло́ся ей, младе́нцу,

Старика́мъ проче́сть

Про жела́нную свобо́ду

Дорогу́ю вйсть!

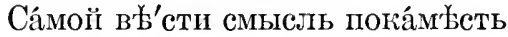

Тёменъ пмъ и ей:

Но веђ чу́ютъ надт собо́ю

Зо́рю но́выхъ дней.

Ма́йковъ.

\section{LXVIII}

\section{ІІЕСТЬДЕСЯТЬ ВОСЬМОЙ УРОКЪ}

По печа́тному: Printed matter, something printed.

Не сльза́в шій . ..... дъъдт: Grandfather who had not climbed down from the stove for many years; the enormous stove of a Russian $i z b a$ serves, among many other things, as a lounge.

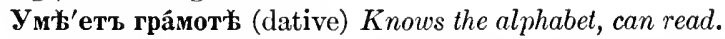

Жела́ ный: A passive past participle, formed from an imperfective verb; 69 В 2. 
New Verbs:

Perfective by Prefix:

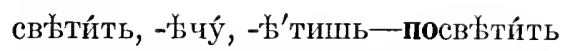

молча́ть, -а́ю--3а-, по-, смолча́ть

жела́ть, -а́ю一пожела́ть чу́ять, чу́ю-почу́ю.

Imperfective by Stem Variation:

собира́ть, -а́ю—собра́ть, -беру́, -берёшь

унима́ть, -а́ю-уня́ть, уйму́, уймёшь

сльза́ть, -а́ю-слх́сть, -зу́, 'зешь

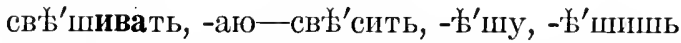

прочи́тывать, -аю一проче́сть, -чту́, -чтёшь (прочита́ть, -а́ю).

Different Stems:

приходи́ть, -хожу́, -хо́дишь-притти́, приду́, придёшь.

No Perfective Aspect:

мерца́ть, -а́ю.

\section{LXIX \\ IIЕСТЬДЕСЯТЬ ДЕВЯТЫЙ УРОКТ}

68. The Verbal Adjectives:

А 1. Въ'теръ бушу́я во́етъ (VIII A).

Живо́тъ спаса́я (XIX).

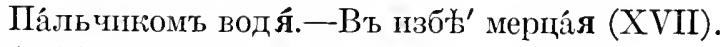

2. (сдь'⿱㇒日勺'лав ши, пони́кнув ши).

В 1. Сл'ъ'дую щія ко́мнаты (VII).

Могу́чій ру́сскій язи́къ (IX).

Плапу́чей йв (XV).

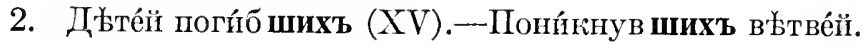

3. (дъ'лаемый, несо́мый).

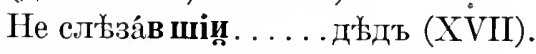

4. Язи́къ..... былъ данъ (IX B).

Про жела́нную свобо́ду (XVII).

The Russian verbal adjectives, instances of which are given above, are rare in conversation, but frequent in literature. The following occur: 
A. UNDECLINED, generally called GERUNDS:

1. The Present Gerund: The ending of the $3 \mathrm{~d}$ plur., утъ, ютъ, ятъ, атъ, is

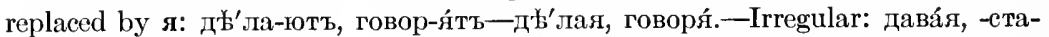
ва́я, -знава́я, from дава́ть, -става́ть, -знава́ть.-It is rarely formed from perfective verbs; if so, it has past meaning: узнáя having learned.

2. The Past Gerund: -лъ of the past tense is replaced by в ши (sometimes въ):

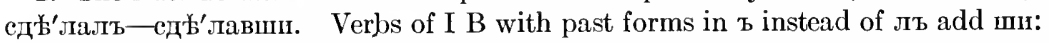
несті́, нёсъ-нёсши; verbs that lose д or $\mathrm{T}$ in the past tense, retain this in the past gerund, and add ши: вести́, вёлъ-ве́дши.-The past gerund of imperfective verbs is rare.

B. DECLINED (called PARTICIPLES):

1. The Active Present Participle: The ending тъ of the $3 d$ plur. is replaced by шій (ща́л, щее): дъ‘' лаю-щцій, говоря́-щцій. An older form of the present participle, ending in учій, ячій, is still used as an adjective, e.g., могу́ чій (VIII), горя́ чій (VI; literally, burning).

2. The Active Past Participle is the declined form of the past gerund: дъ'лавшій, -ая, -е; нёсшій, ве́дшій.

3. The Passive Present Participle is formed by changing мъ of the 1st plur. to мый, мая, мое: дъилаемый; о is written instead of ё: несбмый.

4. The Passive Past Participle (formed almost only from perfective verbs) generally ends in нный (нная, нное; often with one н), with a predicative form in н'ъ,

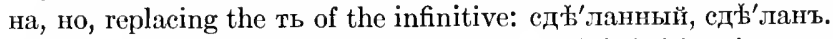

Verbs of class I B and verbs of class II with infinitives in ить add the ending to the present stem with the connecting vowel e (ë), causing consonant softening: заплати́ть-заплачённый, привести́-приведённый.

A few verbs have passive past participles in тый, е.g., закрыть-закрытый.

\section{The Russian Verb System:}

The Russian verb possesses these forms:

\section{Finite Forms}

\section{Imperfective}

Present

Future

Past

Imperative д'ь'лаю

бу́ду дњъ'лать

дъ'лаль

дь' лай

\section{Perfective}

$$
\begin{aligned}
& \text { сдц'ь'лаю }
\end{aligned}
$$

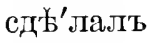

$$
\begin{aligned}
& \text { сдь'лай }
\end{aligned}
$$

\section{Verbal Adjectives}

\begin{tabular}{|c|c|c|}
\hline Pres. act. & ды'抽, ды安'лающій & (сдњ’’лая) \\
\hline Pres. pas & дъ' лаемый & - \\
\hline $\begin{array}{l}\text { Past act. } \\
\text { Past pass. }\end{array}$ & 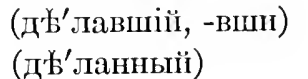 & 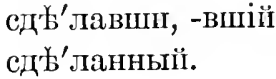 \\
\hline
\end{tabular}


There is only one past tense; there is no future perfect. The passive voice is sometimes expressed by a reflexive verb (cp. Question 1, Lesson 37: Что разска́зывается?), but much more often by the active (егб лю́бятъ he is loved). The particle бы supplies the occasional need of a subjunctive or conditional.

The system of aspects presents some difficulty at the beginning. But if it is understood that for each Russian verb two infinitives and two present tenses must be re membered, just as a number of different forms must be memorized with a great number of verbs in other languages, the student will soon become familiar with the use of the aspects and appreciate the flexibility of expression that they lend to the language.

1. Decline: плаку́чая и́ва, могу́чій язи́нъ, любя́щее дитя́, пони́кнувшая ивв.

2. Form all verbal adjectives of the following verbs: заплати́ть, бро́сить, сказа́ть, говори́ть, посла́ть, забыва́ть, жела́ть, мета́ть.

3. Add the new verbs in this text to your list of verbs.

4. Write for every verb in this text a complete synopsis, as given above

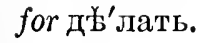




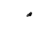

$$
\text { - }
$$




\section{PART TWO SYNOPSIS OF GRAMMAR}





\section{LETTERS AND SOUNDS}

1. The Russian Language is the largest branch of the Slavic or Slavonic group of the Indo-European family of languages. It is subdivided into Great Russian, Little Russian, and White Russian. Great Russian was until very recently the official and literary language of the whole Russian Empire, while Little Russian and White Russian are often considered mere dialects. Of the one hundred and fifteen or one hundred and twenty millions of Russians, about eighty millions belong to the Great Russian group. They inhabit most of European Russia and Siberia; Little Russian, also called Ukrainian or (in former Austria) Ruthenian, is spoken by some thirty millions of people in southern and southwestern Russia; White Russian is the dialect of western Russia, adjacent to Poland.

a. Being an Indo-European language, Russian is related to the Germanic languages (German, Dutch, Scandinavian), the Romance languages (Italian, Spanish, Portuguese, French, Rumanian), Greek, Persian, Armenian, the Hindoo languages, and some minor languages of Europe and Western Asia.

$b$. The three branches of Russian form the Eastern group of the Slavic languages. Polish, Czech, and Wendish are termed West-Slavic, and Bulgarian, Serbo-Croatian, and Slovenian are the South-Slavic languages.

2. The Russian Alphabet, called the Cyrillic, is said to have been invented by Saint Cyrillos, a Greek-Bulgarian missionary, who in the ninth century brought Christianity to some of the Western Slavs. It is based on the Greek alphabet, with the addition of some letters of Semitic origin and some specially invented signs. The Greek letters in the Russian alphabet have, of course, the sound value that they had in the Greek language of the time of Cyrillos; thus, B stands for the sound [v], in (a form of Greek eta) for the sound [i].

3. Phonetic Transcription.-The Russian alphabet is much better adapted to represent the sounds of the Russian language than the common Latin alphabet is suited for the requirements of the English language. Still, the discrepancies between sound and letter are wide enough to make a phonetic transliteration indispensable to the beginner. This book uses the system of the Association phonétique internationale, 
somewhat modified by practical considerations. The following signs are used:

1. Accented Vowels (bold-face type).
[i] as in see
[u] as in put
[e] as in German geh
[o] as in lord
[z] as in French fait
[ы] between German $\ddot{u}$ and French $e$ in je
[a] as in far
[i] similar to German $\ddot{i}$ in Gliick.

2. Unaccented Vowels.

$[\mathrm{a}, \varepsilon, \mathrm{i}, \mathrm{o}, \mathrm{u}, \mathrm{bI}, \mathrm{i}]$ are similar in sound to the corresponding accented vowels, but pronounced with much less tension of the muscles of the tongue. In rapid speech, all of them are more or less slurred.

[I] indicates a slurred vowel of variable quality, ranging from the sound of $a$ in hat in slow speech to slurred [i] ( $y$ in pretty) in fluent pronunciation.

3. Palatal ('soft') Vowels are not indicated as such by any special characters; they are preceded by [j] in initial position and after vowels; preceding consonants are printed in italics: [jedu, delajut].

4. Normal ('hard') Consonants.

$[\mathrm{p}, \mathrm{t}, \mathrm{k}]$ as in grape, date, rake (unaspirated)

$[\mathrm{b}, \mathrm{d}, \mathrm{g}]$ as in $b a d, d o g$, but more voiced

$[\mathrm{m}, \mathrm{n}]$ as in $\operatorname{man}$

$[\mathrm{f}, \mathrm{v}, \mathrm{s}, \mathrm{z}]$ as in fever, seize

[1] as in low, but more 'hollow'

[r] trilled tongue tip-r, as spoken by telephone operators in three

$[\mathrm{x}, \gamma]$ as in German wachen, North German wagen

[j] as in yes.

5. Palatal ('soft') Consonants.

$[t, d, n, l, r]$ denote genuine 'palatals,' as described on page 16. ['] after final $[t]$ denotes a voiceless palatal glide, like weak German $c h$ in

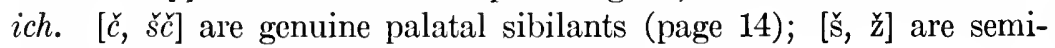
palatal sibilants, like English sh in shoe, $s$ in measure.

\section{Pronunciation (Alphabetical List):}

a $\left\{\begin{array}{l}\text { [a] мать } \\ \text { [a] ко́мната } \\ \text { [i] жарá } \\ \text { [I] тасá }(10,2)\end{array}\right.$

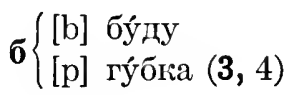

$$
\begin{aligned}
& \text { в }\left\{\begin{array}{l}
{[\mathrm{v}] \text { вы }} \\
{[\mathrm{f}] \text { ла́вга }(3,4)}
\end{array}\right.
\end{aligned}
$$




$$
\begin{aligned}
& \mathbf{r}\left\{\begin{array}{l}
{[\mathrm{g}] \text { годъ }} \\
{[\mathrm{k}] \text { могъ }(3,4)} \\
{[\gamma] \text { Бо́га }(3,6)} \\
{[\mathrm{x}] \text { Богъ }} \\
{[\mathrm{v}] \text { б б'лаго }(34,4)}
\end{array}\right. \\
& \text { д }\left\{\begin{array}{l}
{[\mathrm{d}] \text { домъ }} \\
{[\mathrm{t}] \text { годъ }(3,4)} \\
{[d] \text { д'́ }(18,2)} \\
{\left[t^{\prime}\right]}
\end{array}\right.
\end{aligned}
$$

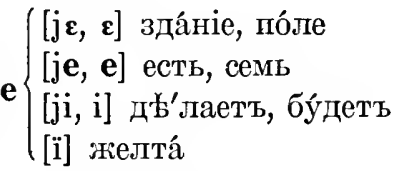$$
\text { ë }[\mathbf{j o}, \mathbf{o}] \text { даётъ, кладёмъ }
$$$$
\text { ж\{l}\left\{\begin{array}{l}
{[\check{]}] \text { мужи́кь }} \\
{[\check{s}] \text { ло́жка }}
\end{array}\right.
$$$$
\text { [z] за́втра }
$$$$
3\{\text { [s] разъ }(3,4)
$$$$
\text { [ร̌] ' изво́зчикъ }[11, \text { e) }
$$$$
\text { ([ji, i] пхъ, ни́ва, и́ва }
$$$$
\mathbf{n}\{\text { [i] э́ти, сто́итъ }
$$$$
\text { [i, ï] ӝиль, живо́ть }
$$$$
\mathbf{i}\left\{\begin{array}{l}
{[\mathbf{i}] \text { міръ }(17,1)} \\
{[i] \text { зда́ніе }[12, B)}
\end{array}\right.
$$$$
\text { й }\{\text { j] мой (10) }
$$$$
\text { й }\{[-] \text { or }[j] \text { бъ' }
$$$$
\mathbf{\kappa}\left\{\begin{array}{l}
{[\mathrm{k}] \text { какъ }} \\
{[\mathrm{x}] \text { кто }(3,6)}
\end{array}\right.
$$$$
\text { л }\left\{\begin{array}{l}
{[1] \text { поль }} \\
{[l] \text { по́ле }}
\end{array}\right.
$$$$
\text { м [м] мы }
$$$$
\mathbf{H}\left\{\begin{array}{l}
{[\mathrm{n}] \text { на }} \\
{[n] \text { не }}
\end{array}\right.
$$$$
\mathbf{o}\left\{\begin{array}{l}
{[\mathbf{o}] \text { поль }} \\
{[0] \text { э́то }} \\
{[\text { a] доска́ }}
\end{array}\right.
$$

II [p] поль

$\mathbf{p}\left\{\begin{array}{l}{[\mathrm{r}] \text { чёрный }} \\ {[r] \text { царь }}\end{array}\right.$

c $\left\{\begin{array}{l}{[\mathrm{s}] \text { садъ }} \\ {[s ̌] \text { сча́стье }(11 \mathrm{e})}\end{array}\right.$

$\mathbf{T}\left\{\begin{array}{l}{[t] \text { э́то }} \\ {\left[t, t^{t}\right] \text { э́ти, дать }}\end{array}\right.$

$\mathbf{y}\left\{\begin{array}{l}{[\mathrm{u}] \text { стуль }} \\ {[\mathrm{u}] \text { бума́га }}\end{array}\right.$

ф [f] фи́зика

x [x] хорошо́

ц [ts] царь

ч [č чась

III [š] широ́кій

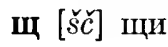

ъ [-] столь

ы [ы, ы] сынб́

b ['] дать

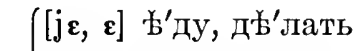

$$
\begin{aligned}
& \text { [je, e] ъсть, дъ'ти } \\
& \text { * [ji, i] вда́, дъли́ть } \\
& \text { [i] цоэпень'ть } \\
& \text { [o] зв б'зды } \\
& \text { э }\left\{\begin{array}{l}
{[\varepsilon] \text { э́то }} \\
{[\mathbf{e}] \text { э́ти }}
\end{array}\right. \\
& \text { ю }\left\{\begin{array}{l}
{[\mathrm{ju}, \mathrm{u}] \text { люблю́ }} \\
{[\mathrm{ju}, \mathrm{u}] \text { д㔚'лаго, люблю́ }}
\end{array}\right.
\end{aligned}
$$

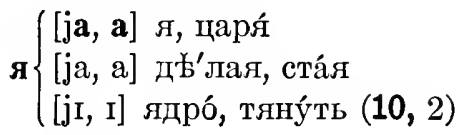

$$
\begin{aligned}
& \text { ( [f] Өе́дя. }{ }^{1}
\end{aligned}
$$

${ }^{1} \boldsymbol{\theta}$ is called өита́; it occurs only in a few foreign words and is generally replaced by ф: ка́өедра = ка́федра. 
5. Sound Changes.-Neighboring sounds influence one another in all languages, but there is hardly any language in which this influence is more marked than in Russian. Numerous instances have been mentioned in the table above, e.g., вк, зк, гк $=[\mathrm{fk}, \mathrm{sk}, \mathrm{xk}]$. The allpervading tendency towards palatalization is another symptom of this yielding, elastic quality of Russian sounds. But two groups of sound changes are of especial grammatical importance:

1. Consonant Softening, compare $\mathbf{5 0 .}$

Before palatal vowels and $\mathrm{b}$, the following changes take place:
r, Д, 3 , change to $\boldsymbol{K}$
$\mathbf{K}, \mathbf{T}, \mathbf{ц}$ change to $\mathbf{\Psi}$
$\mathbf{x}$, change to $\mathbf{\text { III }}$
ск, ст change to $щ$.

2. Vowel Variation; compare 12, 30, 33.

The soft vowels (я, е, ё, и, ю) and $\mathbf{b}$, which are very frequent in inflectional endings, are subject to certain principles of compatibility - with consonants:

a. After velars $(\mathbf{k}, \mathbf{r}, \mathbf{x})$ - $\mathbf{g}, \ddot{\mathbf{e}}, \mathbf{ю}$, ы are replaced by a, o, у, и.

b. After the sibilants ч, щ, $\mathbf{ш}, ж$, and ц-я, ю are replaced by a, y, and $\mathbf{o}$ in unaccented endings by $\mathbf{e}$.

c. After ч, щ, ш, ж (not after ц)-ы is replaced by и; on the other hand, in does not stand after $\amalg$, except in foreign words.

d. After i- $\mathbf{-}$ is replaced by $и$.

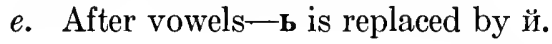

\section{ACCENT}

6. The Russian Accent is mobile or variable, i.e., it may change its place in a given word. Definite rules cannot be given. Careful observation of the accent marks that are generally given in beginners' texts and dictionaries is the only safe way of acquiring it--unless the student has ample opportunity of hearing Russian.

As far as they go, the following hints may be of some assistance:

NOUNS.

1. Masculines, if monosyllabic, are apt to throw the accent on the ending, but if polysyllabic generally do not change their accent: столъ-стола́, уро́къ-уро́ка (but каранда́шъ, язы́къ, паде́жъ and many others with accented final stem syllable accent the ending: карандаша́).

2. Feminines generally change the accent in the nominative plural if the singular accents the ending: жена́-жёны (but жена́мъ).

3. Neuters in o or e of two syllables reverse the accent in the plural: сло́во-слова́, стекло́-стёкла.

ADJECTIVES.

1. Attributive adjectives do not change their accent: ширб́кій-широ́каго, болшбй-большо́го. 
2. Predicative adjectives and past tense forms of two syllables are apt to accent the ending in the feminine singular: чёренъ-черна́-чёрно-чёрни; былъбыла́-бы́ло一бы́ли. But other accent types occur; compare 23, 60, and page 22.

VERBS.

1. Present.

a. If the infinitive ending is unaccented, the accent does not change: див'лать-

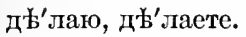

$b$. If it is accented, the accent may remain on the ending, or it may be thrown back on the stem from the $2 \mathrm{~d}$ sing. on: говори́ть-говорю́, говори́шь; писа́ть - пишу́, пи́шешь.

2. Past.

The accent rests on the same syllable as in the infinitive; but if the masculine has only one syllable, the feminine is apt to accent the ending: былъ, была́, би́ло.

\section{DECLENSION—CKJOHEHIE}

\section{The Noun-Имя су ществи́тельное}

7. Gender-родъ. 'There are three genders:

Masculine-му́жескій родъ,

Feminine-же́ескійі родъ,

Neuter-сре́дній родъ.

The gender of nouns is determined:

a. By their meaning: Names of male beings are masculine, names of female beings feminine, regardless of their terminations: мужъ man, слуга́ valet, дя́дя uncle are masculine, жена́ woman, ня́ня nurse, feminine.

b. By their ending:

Nouns in ъ or й are masculine: столъ table, мужъ man, геро́й hero, capáü barn.

Nouns in $\mathbf{a}$ and я (not мя) are feminine: женá woman, доска́ board, нед

Nouns in о, е, мя are neuter: сло́во word, по́ле field, и́мя name. Also дитя́ child is neuter.

Nouns in $\mathbf{b}$ can be either masculine or feminine: учи́тель teacher is masculine, ло́шадь horse, feminine.

8. Case-паде́жъ. There are six cases in Russian:

Nominative-имени́тельный паде́жъ

Accusative-вини́тельный паде́жъ

Genitive-роди́тельный паде́жъ 
Locative or Prepositional-предлóжный паде́жъ

Dative一да́тельный паде́жъ

Instrumental一твори́тельный паде́жъ.

Note.-There are a few remains of an old vocative (case of address), namely: Бо́же, voc. of Богъ God, Го́споди [hospadi], voc. of Госпо́дь Lord, and O'тче, voc. of оте́цъ father, used only in the Lord's Prayer: О'тче нашъ.

9. Number-числь́.-In the regular declensions there are two numbers: The singular-еди́нственное число́-and the plural-мно́жественное число. But there are considerable remains of an old dualдво́йственное число; this was originally used of things occurring in pairs, but gradually gave rise to a frequent type of irregular plural formation. The dual meaning is still seen in:

глазъ一глаза́ eyes

бéperъ-берегá shores, banks

рогъ-porá horns у́хо-у́ши ears

плечо́-плечи́ shoulders

коль' 'но一коль' 'ни knees.

Another trace of the dual is found in the apparent gen. sing. which is used after the numbers two, three, four, and in $200=$ двьсти.

10. Hard and Soft Nouns.-Nouns that end in $\mathbf{b}, \mathbf{a}, \mathbf{o}$ in the nom. sing. are called hard; those that end in $\mathbf{b}, \mathbf{\mathbf { n }}, \mathbf{8}, \mathbf{e}$ are called soft. But the laws of vowel variation (12 $\mathrm{A}$ and $\boldsymbol{\Upsilon} 5,2)$ often require hard endings with soft nouns and vice versa.

\section{Table of Endings:}

Hard and soft endings are separated by dashes.

\begin{tabular}{|c|c|c|c|c|c|c|}
\hline & \multicolumn{3}{|c|}{ Singular } & \multicolumn{3}{|c|}{ Plural } \\
\hline & $\mathrm{M}$ & $\mathrm{N}$ & $F$ & M & $\mathrm{N}$ & $\mathrm{F}$ \\
\hline Nom. & $\mathbf{b}-\breve{\mathbf{n}}, \mathbf{b}$ & \multirow{2}{*}{$0-\mathrm{e}$} & $\mathbf{a}-\mathbf{g}, \mathbf{b}$ & $\mathbf{b}-\mathbf{n}$ & $a-g$ & ы-и \\
\hline Acc. & $=\mathrm{N}$. or $\mathrm{G}$. & & $y-10$ & \multicolumn{3}{|c|}{$=\mathrm{N}$. or Gen. } \\
\hline Gen. & \multicolumn{2}{|c|}{$\mathbf{a}-\mathbf{g}$} & bI-K & ов'-一в'ъ, ей & $\mathbf{\mathbf { b }}-\breve{\mathbf{u}}, \mathbf{e и ̆}$ & $\mathbf{b}-\mathbf{b}, \mathbf{\mathbf { n }}$ \\
\hline Loc. & \multicolumn{3}{|c|}{ 苦 } & \multicolumn{3}{|c|}{$\mathbf{a x b}-\mathbf{g x \mathbf { b }}$} \\
\hline Dat. & \multicolumn{2}{|c|}{$y-10$} & 古 & \multicolumn{3}{|c|}{ амъ-ямъ } \\
\hline Inst. & \multicolumn{2}{|c|}{ омъ-емъ } & ой-ей & \multicolumn{3}{|c|}{ ами-ями } \\
\hline
\end{tabular}


Feminines in $\mathbf{b}$ and neuters in мя:

\begin{tabular}{|c|c|c|c|c|c|c|}
\hline & $\mathrm{N}$ & A & $\mathrm{G}$ & $\mathrm{L}$ & $\mathrm{D}$ & I \\
\hline \multirow{2}{*}{ Sing. } & . & b & \multicolumn{3}{|c|}{$\mathbf{n}$} & Бю \\
\hline & & мя & \multicolumn{3}{|c|}{ мени } & менемъ \\
\hline \multirow{2}{*}{ Plur. $\begin{array}{l}\text { F. } \\
\text { N. }\end{array}$} & и & N. or G. & ей & яXЪ & ямъ & ями \\
\hline & & мена & менъ & менахъ & менамъ & менами \\
\hline
\end{tabular}

12. Paradigms:

\section{Masculines}

\section{Hard}

Soft

Sing. N. столь

A. столь

волкъ

G. стола́

во́лка

L. столь'

во́лка

D. столи́

во́лкњ

I. столо́мъ

во́лку

во́лкомъ

Plur. N. столь́

А. столь́

во́лки

G. столо́въ

волко́въ

L. стола́хъ

волко́въ

D. стола́мъ

волка́хъ

I. стола́ми

волка́мъ

волка́ми

\begin{tabular}{|c|c|}
\hline царь & геро́й \\
\hline цар я́ & геро́я \\
\hline царя́ & геро́я \\
\hline царњ⿱一𧰨 & repót \\
\hline царю́ & геро́ю \\
\hline царёмъ & геро́емъ \\
\hline цари́ & геро́и \\
\hline царе́й & геро́евъ \\
\hline царе́й & геро́евъ \\
\hline царя́ххъ & геро́яхъ \\
\hline $\begin{array}{l}\text { цар я́мъ } \\
\text { цар я́ми }\end{array}$ & $\begin{array}{l}\text { геро́ямъ } \\
\text { геро́ями }\end{array}$ \\
\hline
\end{tabular}

Neuters

Hard

Sing. N.,A. окно́

G. окнá

L. oкH'b'

D. окнý

I. окно́мъ

Plur. N.,A. о́кна

G. о́конъ

L. о́кнахъ

D. о́кнамъ

I. о́кнами

по́ле

по́ля

по́лซ

по́лю

по́лемъ

пол я́

по́ле́й

пол я́хъ

пол я́мъ

Soft

зда́ніе

зда́нія

зда́ніи

зда́нію

вре́мя

вре́мени

вре́мени

вре́мени

зда́ніемъ

вре́менемъ

зда́нія

времена́

зда́ній

времёнт

зда́ніяхъ

времена́хъ

зда́ніямъ

времена́мъ

зда́ніями

времена́ми 
Feminines

Hard

Sing. N. жена́

A. жени́

G. жень́

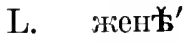

D. жене

I. жено́й

Plur. N. жёны

A. жёнт

G. жіёнъ

L. жёнахъ

D. жёнамъ

I. жёнами

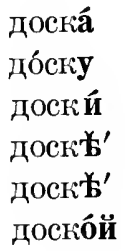

до́ски

доо́кии

досо́къ

доска́xъ

доска́мъ

доска́ми
Soft

\begin{tabular}{|c|c|}
\hline вемл я́ & дверь \\
\hline зе́млю & дверь \\
\hline земли́ & две́ри \\
\hline земл蓠' & две́ри \\
\hline вемл虔 & две́ри \\
\hline вемле́й & две́рью \\
\hline ве́мли & две́ри \\
\hline зе́мли & две́ри \\
\hline веме́ль & двере́й \\
\hline земл я́х & дверйхт \\
\hline земл ймъ & двери́мъ \\
\hline земл Я́ми & дверя́м и \\
\hline
\end{tabular}

\section{Lengthened Stems:}

a. Neuters in мя, like и́мя first name, пла́мя flame, вре́мя time, съъ’мя seed, зна́мя standard; see above, paradigm of вре́мя.

$b$. мать mother, дочь daughter, дітя́ child.

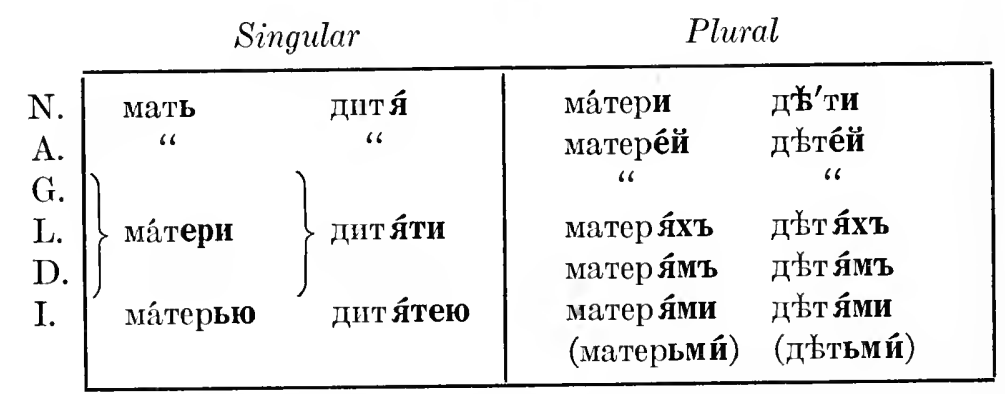

(Case endings like дверь; дочь like мать.)

\section{Masculine:}

1. The accusative of both numbers has the form of the nominative with things, but the form of the genitive with living beings.

2. The rules of variation cause the following changes:

a. The instrumental singular ends in емъ instead of омъ with nouns that have stems in $\mathbf{ц}, \mathbf{\amalg}, \boldsymbol{ж}, \mathbf{щ}, \mathbf{ч}$, provided the ending is not accented: ножь knife-ножо́мъ, but ключь key-ключемъ.--Nouns in $\mathbf{b}$ and й have the instr. sing. ending ёмъ if accented, емъ if unaccented: царёмъ -геро́емт. 
b. The genitive plural ends in eй with nouns in $\mathbf{b}$ and with those that have stems in шI, ж, ч, щ, but in евъ with nouns in й: царе́й-поже́й -геро́евъ. Stems in ц also have евъ if the ending is unaccented, but

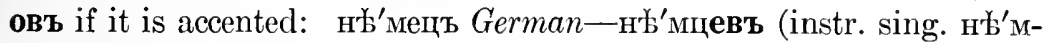
цемъ), but оте́цъ father-отцо́въ (instr. sing. отцо́мъ).

c. The nominative plural takes $\mathbf{n}$ instead of $\mathbf{m}$ if the stem ends in a velar or a palatal sibilant: (к, $\mathbf{r}, \mathbf{x} ; \mathbf{ш , ~ ж , ~ ч , ~ щ ) ~ в о л к ъ - в о ́ л к и , ~}$ ножъ-ножий (but оте́цъ-отци́).

3. Vowel Insertion: Nouns with $\mathbf{e}$ or $\mathbf{o}$ in the last syllable of the nom. sing. generally drop this in the oblique cases, (a) if the accent shifts to the ending, (b) if the accent is on the first syllable in all cases:

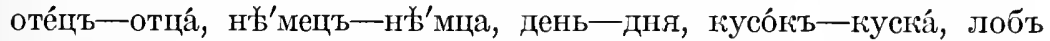
forehead-лба. But if more than two consonants would meet, the vowel is usually retained, e.g., мудре́цъ sage-мудреца́.

4. Locatives in $\hat{y}$ : A number of words denoting place take ý-1́ (always accented) in the locative singular after the two prepositions въ and на: въ шкапу́ in the cupboard, на полу́ on the floor. The most common nouns of this kind are: поль floor, у́голь (въ угу́) corner, шкапъ cupboard, садъ garden, лугъ meadow, прудъ pond, лъсъ forest, край border, лобъ forehead, ротъ mouth (во рту), носъ nose, зубъ tooth, часъ hour, годъ year.

4. Genitives in $\mathbf{y : ~ S o m e ~ n o u n s ~ d e n o t i n g ~ m a t e r i a l s ~ a n d ~ a ~ f e w ~ n o u n s ~}$ that are often used in adverbial phrases have a gen. sing. in -y, e.g., чай $t e a$, са́харъ sugar, снбъгъ snow, край edge, бой fight, assault, часъ hour, л宅ъ forest, e.g., ча́шка ча́ю a cup of tea, съ ча́су на часъ from hour to hour, и́зъ-лŁсу out of the forest.

5. Plurals in $\mathbf{a}-\boldsymbol{\mathbf { \beta }}$. Compare 9 , where the following plurals are mentioned: глазá, берегá, poгá; others are: бокъ side-бока́, домъ house-дома́, го́лосъ voice-голоса́, го́родъ town-города́, до́кторъ doctor-доктора́, учи́тель teacher-учителя́, хль̌бъ-хл'ъба́ crops

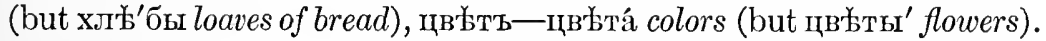

Plurals in ья: брать brother-бра́тья, стуль chair-сту́лья, листъ sheet-ли́сты (but ли́стья leaves), мужъ man-му́жи citizens (but мужья́ husbands). Most of these have -ьевъ (бра́тьевъ) in the gen. pl., but a few have -ей (муже́ĭi).

Other irregular plurals:

a. Сынъ son-сыновья́, сынове́й, сыновья́хъ, etc.; сосъ'дъ neighbor-сось'ъди, чёртъ devil-че́рти (declined like цари́).

b. Nouns in анинъ (denoting nationality, religion, social standing), like гражддани́нъ citizen, крестья́нинъ peasant, христія́нинъ Christian, 
англича́нинъ Englishman, славья́нинъ Slav, have plurals in ане, gen. -анъ, loc. -анахъ, еtc.: гражда́нинъ-гражда́не.-Similar are:

Господи́нъ $M r$. - господа́ Gentlemen, хозя́инъ housekeeper一хозя́ева.

A few nouns have a regular nom. pl., but a gen. pl. in $\mathbf{b}$, like neuters in о, e.g., во́лосы hair-gen. во́лосъ, разъ time-gen. pl. разъ (де́сять разъ ten times), солда́тъ soldier-солда́тъ; человł'къ man, human being has a gen. pl. челов'ъ'къ after numerals only; otherwise, лю́ди people is used instead of a plural of человъ'

\section{Feminines:}

1. The accusative singular ends in $\mathbf{y}-\mathbf{0}$ with nouns in $\mathbf{a}-\mathbf{9}$, and in $\mathbf{b}$ with nouns in $\mathbf{b}$; but the accusative plural is like the nominative in the case of things and like the genitive in the case of living beings.

2. The instrumental singular has a shorter form in ой-ей and a longer form in or-eю, but the former is far more common, especially in conversation.

3. Masculines in $\mathbf{a}-\mathbf{g}$ are declined exactly like feminines of the same form: слуга́ valet, gen. слуги́, Вáня, diminutive of Ива́нъ, gen. Ва́ни.

4. Vowel variation requires the following changes:

a. The instrumental singular ends in eй with nouns in ца, ша, жа, ча, ща, provided the ending is unaccented: да́ ча country seat-дáчей, but душа́ soul一душо́ї (душо́ю).

$b$. The genitive singular and nominative plural end in и instead of ы with stems in velars and palatal sibilants: доска́-доски́, до́ски; душа́-души́, ду́ши.

c. Nouns in ія change the $\mathrm{s}$ of the dative and locative singular to и: фами́лія-фами́ліи; those in я after any vowel change $ь$ of the genitive plural to й: фами́лій, ста́я-ста́й.

5. Vowel Insertion: If the stem ends in two consonants, vowel insertion takes place in the genitive plural according to $12 \mathrm{C}$ : ло́жка-ло́жекъ; compare 37, 3.

If the final consonant of the stem is preceded by ь or й, this is changed to e: судьба́ fate-суддебъ, копе́йка kopeck-копе́екъ. Likewise, $\mathrm{b}$ at the end of a stem, as in судья́ judge, is changed to e, and the genitive ending в, standing after a vowel (see above), becomes й: суде́й.-Дя́дя uncle has the genitive plural дя́дей in analogy with maculines like царь-царе́й.

\section{Neuters:}

1. Only few neuters, such as nóлe field and мópe sea, end in e after a consonant, but many neuters end in ie, like зда́нie; a few concrete nouns end in ье (е.g., пла́тье clothing); abstract nouns in ie can also be spelled with ье: мнгове́ніе, мнгове́нье moment. When spelled with ie, they 
are declined like зда́ніе, when spelled with ье, like пóлe; but some take ьевъ instead of ей (like поле́ї) in the genitive plural: пла́тьевъ.

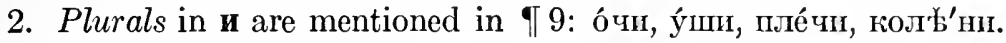
In the oblique cases these nouns go like сло́во, but in the genitive often

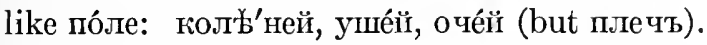

Plurals in -еса: небо heaven-небеса́; чу́до wonder-чудеса́.

3. The genitive plural ends in овъ-евъ with the following neuters:

a. Nouns in ье, see above (пла́тьевъ; but, e.g., ружьё gun一руже́й).

b. О'блако cloud-обблака, о́блаковъ, очки́ spectacles-очко́въ, су́дно vessel-суда́, судо́въ; де́рево tree-дере́вья, дере́вьевъ; перо́ feather, pen一пе́рья, пе́рьевъ; крыло́ wing-кри́лья, кри́льевъ.

4. Nouns in ёнокъ (denoting young living beings) are masculine in the singular, but neuter, with suffix я́та instead of ёнокъ, in the plural:

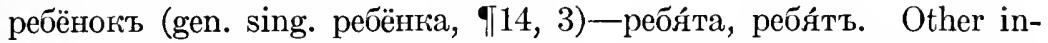
stances are given in Lesson LXV, Notes.-These nouns, like дитя́ child, use the form of the genitive for the accusative plural, but with all other neuters the accusative (sing. and plur.) is like the nominative.

5. Vowel Variation must be observed: учи́лище schoolучи́лищемъ, зда́ніе building зда́ніи, genitive plural зда́ній.

6. Vowel Insertion according to $12 \mathrm{C}$ takes place if the genitive plur. has no ending: окно́ window-о́конъ. Яйцо́ egg has the gen. pl. яи́цъ.

\section{The Pronoun-MЊстоимé hiе}

17. Personal Pronouns.-ли́чныя мъстоиме́нія.

1st $\quad 2 \mathrm{~d}$

$3 \mathrm{~d}$

$\overbrace{\text { M. N. F. F. }}^{3}$.

Sing. N.

A.

G.

L.

D.

I.

Plur. N.

A.G.L.

D.

I.

\begin{tabular}{|c|c|c|c|}
\hline $\begin{array}{l}\text { я } \\
\text { меня́ } \\
\text { мнґ́ } \\
\text { мной, } \\
\text { мно́ю }\end{array}$ & $\begin{array}{l}\text { ты } \\
\text { тебя́ } \\
\text { теб́女' } \\
\text { тобо́й, } \\
\text { тобо́ю }\end{array}$ & $\begin{array}{l}\underbrace{\text { онъ онб́ }}_{\text {его́ }} \\
\begin{array}{l}\text { нёмъ } \\
\text { ему́ } \\
\text { имъ }\end{array}\end{array}$ & $\begin{array}{l}\text { она́ } \\
\text { её } \\
\text { ея́ } \\
\text { ней } \\
\text { ей } \\
\text { ей }\end{array}$ \\
\hline $\begin{array}{l}\text { мы } \\
\text { насъ } \\
\text { намъ } \\
\text { на́ми }\end{array}$ & $\begin{array}{l}\text { вы } \\
\text { васъ } \\
\text { вамъ } \\
\text { ва́ми }\end{array}$ & онй́ $\underbrace{}_{\begin{array}{c}\text { (H) } \\
\text { им' } \\
\text { и́м }\end{array}}$ & $\frac{\mathbf{O H} \mathbf{b}^{\prime}}{\mathbf{X \mathbf { b }}}$ \\
\hline
\end{tabular}

Reflexive 
1. The regular pronoun of address is вы, corresponding to French vous, German Sie. Tы is the singular address in intimate conversation and solemn speech.

2. As subjects of verbs, я, ты, etc., are often omitted.

3. The longer instrumental forms мно́ю, тобб́ю, соббю are much more frequent than the longer instrumental forms of feminine nouns.

4. The difference between они́ and он'ъ' is only onc of spelling; both are pronounced [ani]; eё and eя́ $=[$ jijo] $]$.

5. The oblique cases of the third person have an $\mathbf{н}$ prefixed if a preposition precedes: для него́, у нея́, къ нему́, къ ней, съ нимъ, у нихъ, еtc.

6. The genitives of the third person are used as non-reflexive possessive pronouns: его́ домъ, ея́ ко́мната, his house, her room.

7. The forms of the reflexive pronoun are the same for all persons and numbers; compare 36.

18. Possessive Pronouns-усвои́тельныя мъстонме́нія.

\begin{tabular}{|c|c|c|c|c|c|c|}
\hline & \multicolumn{3}{|c|}{ мой $m y$} & \multicolumn{3}{|c|}{ на шъ our } \\
\hline & \multicolumn{2}{|c|}{ N. } & $\mathrm{F}$. & \multicolumn{2}{|c|}{ N. } & F. \\
\hline $\begin{array}{r}\text { Sing. N. } \\
\text { A. }\end{array}$ & $\begin{aligned} & \text { мой } \\
= & \underbrace{\mathrm{N}}, \mathrm{G} .\end{aligned}$ & $\begin{array}{c}\text { Mo } \\
\text { 6 }\end{array}$ & $\begin{array}{l}\text { Мо Я́ } \\
\text { Мою́ }\end{array}$ & $\begin{aligned} & \text { нашть } \\
= & \underbrace{\mathrm{N}}, \mathrm{G} .\end{aligned}$ & $\begin{array}{l}\text { Háme } \\
\text { ، }\end{array}$ & $\begin{array}{l}\text { нáwa } \\
\text { нáщy }\end{array}$ \\
\hline $\begin{array}{l}\text { G. } \\
\text { L. } \\
\text { D. } \\
\text { I. }\end{array}$ & $\begin{array}{l}\text { moel } \\
\text { moëi } \\
\text { moen } \\
\text { moи́ }\end{array}$ & & мое́й & $\begin{array}{l}\text { нáш } \\
\text { нáш } \\
\text { нám } \\
\text { нáш }\end{array}$ & $\begin{array}{l}\text { ro } \\
\text { Mъ } \\
\text { My } \\
\text { Mb }\end{array}$ & на́шей \\
\hline $\begin{array}{r}\text { Plur. N. } \\
\text { A. } \\
\text { G.L. } \\
\text { D. } \\
\text { I. }\end{array}$ & $=$ & 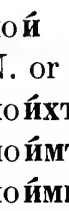 & & & $\begin{array}{l}\text { нáши } \\
\text { N. or } \\
\text { на́ших } \\
\text { на́шим } \\
\text { на́шим }\end{array}$ & \\
\hline
\end{tabular}

1. The acc. masc. and neut. sing. and the acc. plur. of all three genders have the form of the nominative with things, the form of the genitive with living beings.

2. For the instr. sing. fem. the longer forms мое́ю, на́шею are fairly frequent.

3. -ro of the gen. sing. is pronounced [vo].

The other persons are:

Твой $t h y$, your, and свой his, her, its, their (reflexive, compare 36) are declined like мой.

Вашъ your is declined like нашъ.

19. Demonstrative Pronouns-указа́тельныя мұстоиме́нія.

1. $\boldsymbol{J}^{\prime}$ тоть this, that is the usual demonstrative pronoun in the real 'sense of the word, i.e., pointing to a certain thing. 
2. Tотъ that is generally used as a correlative, i.e., as antecedent of a relative clause or a that-clause. Besides, it is frequently connected

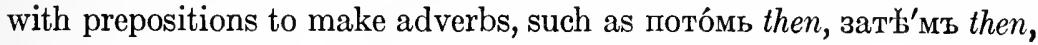
кро́м того besides. Followed by же it denotes identity: тотъ же мужъ the same man.

3. Сей this is now practically obsolete with the exception of a few frequent phrases, e.g., сей чáç now, сію́ мину́ту this minute, до сихъ поръ until now, сего́дня today.

\begin{tabular}{|c|c|c|c|c|c|c|}
\hline & \multicolumn{3}{|c|}{ бтоть } & \multicolumn{3}{|c|}{ тоть } \\
\hline & M. & N. & F. & M. & N. & F. \\
\hline $\begin{array}{r}\text { Sing. N. } \\
\text { A. }\end{array}$ & $\begin{array}{l}\text { б́тоть } \\
\text { N.,G. }\end{array}$ & $\begin{array}{l}\text { 9́то } \\
\text { 9́то }\end{array}$ & $\begin{array}{l}\text { áта } \\
\text { б́ту }\end{array}$ & $\begin{array}{c}\text { тоть } \\
\text { N.,G. }\end{array}$ & $\begin{array}{l}\text { TO } \\
\text { TO }\end{array}$ & $\begin{array}{l}\text { Ta } \\
\text { Ty }\end{array}$ \\
\hline $\begin{array}{l}\text { G. } \\
\text { L. } \\
\text { D. } \\
\text { I. }\end{array}$ & \multicolumn{2}{|c|}{$\begin{array}{l}\text { э́того } \\
\text { б́томъ } \\
\text { э́тому } \\
\text { б́тимъ }\end{array}$} & э́той & \multicolumn{2}{|c|}{ 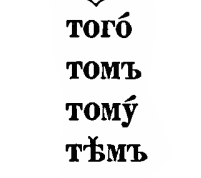 } & той \\
\hline $\begin{array}{r}\text { Plur. N. } \\
\text { A. } \\
\text { G.L. } \\
\text { D. } \\
\text { I. }\end{array}$ & \multicolumn{3}{|c|}{$\begin{aligned} & \text { бти } \\
= & \mathrm{N} . \text { or } \mathrm{G} . \\
& \text { эттихъ } \\
& \text { б́тимь } \\
& \text { б́тими }\end{aligned}$} & \multicolumn{3}{|c|}{ 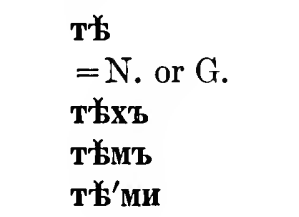 } \\
\hline
\end{tabular}

Pronunciation: - ro $=[\mathrm{vo}]$.

Сей: Nom. Sing. сей, сія́, ciё (сё)

" Plur. ciй

The rest of the declension is like that of мой: сеѓ, сей. . . . cихъ.

Такой such, таково́й of such kind are declined like common adjectives.

20. Interrogative Pronouns-вопроси́тельныя мъ̌стоиме́нія.

1. Pure Pronouns: кто who, что what.

2. Pronominal Adjectives:

чей (чья, чьё) whose (е.g., чей домъ whose house, чья кни́га whose book, чьё перо́ whose pen, чьи дъ'ть'ти whose children);

который which;

како́й, каково́й of what kind, what. 


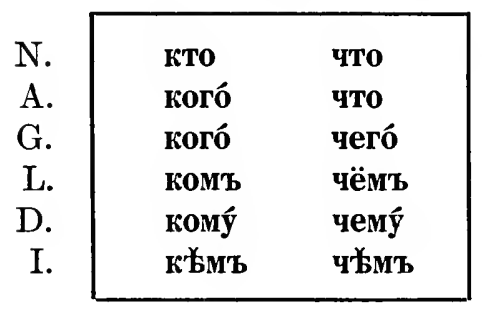

Чей has in the oblique cases the same endings as мой (чьего́, чьей, pl. чьихъ, etc.). Како́й, каково́й have adjective declension.

\section{Relative Pronouns-относи́тельныя мб̌стоиме́нія.}

1. Кто and что are indefinite relative pronouns, corresponding to English whoever, he who-what, whatever: Кто его́ знáeтъ, его́ лю́битъ Whoever knows him, likes him; что зна́ешь, о томъ не спра́шивай do not ask for what you know.

They are often made still more indefinite in their meaning by adding бы ні (with the verb in the past form): Кто бы его́ ни зналь... Everybody who knows him...

2. Кото́рый, declined like an adjective, corresponds to English that, which, who after an antecedent. The relative pronoun is never omitted in Russian: Женá, кото́рую люблю́ The woman I love.

22. Indefinite Pronouns-неопредъ̌лённыя мъ̌стоиме́нія.

1. Affirmative indefinite pronouns are formed by combining interrogative pronouns with н'ъ'-, -нибудь, -лйбо, -то:

нъ' кто (нъ' кого.....), кто́-нибудь, кто-то somebody, a certain;

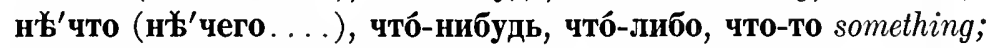

какой-нибудь, како́й-либо, како́й-то, нъ' который some, certain.

2. Negative indefinite pronouns are formed by prefixing ни-, неto interrogative pronouns (не- in the oblique cases):

никто́, никого́.... (не́кого. ...) nobody;

ничто́, ничего́.... (не́чего.....) nothing.

$a$. If a preposition is connected with a negative pronoun, it is put between the two elements: ни съ кЊмъ, не́ съ кŁмъ with no one.

$b$. The object of a negative phrase stands in the genitive; the negation must be repeated with the finite verb: Я никогб́ не впда́лъ, я ничегб́ не дъ'ъ'лалт. The genitive ничегб, used elliptically, has the meaning never mind.

c. Do not confuse нб'кто, нб'чтto with не́кто, не́что.-Notice that ни is unaccented, but $\mathrm{H}^{\prime} \mathfrak{b}^{\prime}$ and Hé are accented. 


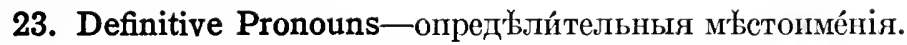

Самъ self, са́мый same, оди́нъ one, alone, ка́ждый, вся́кій each, every, весь all, whole.

\begin{tabular}{|c|c|c|c|}
\hline & M. & N. & F. \\
\hline $\begin{array}{r}\text { Sg. N. } \\
\text { A. }\end{array}$ & $\begin{array}{l}\text { самъ } \\
\text { самоѓ́ }\end{array}$ & $\begin{array}{c}\text { самó } \\
\text { " }\end{array}$ & $\begin{array}{l}\text { camá } \\
\text { caný }\end{array}$ \\
\hline $\begin{array}{l}\text { G. } \\
\text { L. } \\
\text { D. } \\
\text { I. }\end{array}$ & \multicolumn{2}{|c|}{$\begin{array}{l}\text { самого́ } \\
\text { само́мъ } \\
\text { самомý } \\
\text { сами́мт }\end{array}$} & само́й \\
\hline $\begin{array}{c}\text { Pl. N. } \\
\text { A. } \\
\text { G.L. } \\
\text { D. } \\
\text { I. }\end{array}$ & & $\begin{array}{l}\text { са́ми } \\
\text { сами́хт } \\
\text { “" } \\
\text { самйм' } \\
\text { сами́м }\end{array}$ & \\
\hline
\end{tabular}

Singular

\begin{tabular}{|c|c|c|}
\hline M. & N. & F. \\
\hline $\begin{array}{l}\text { оди́ни } \\
\text { одного́ }\end{array}$ & $\begin{array}{c}\text { однб́ } \\
\text { “" }\end{array}$ & $\begin{array}{l}\text { одна́ } \\
\text { одни́ }\end{array}$ \\
\hline \multicolumn{2}{|c|}{$\begin{array}{l}\text { одного́ } \\
\text { одно́мъ } \\
\text { одному́ } \\
\text { одни́мъ }\end{array}$} & однбй \\
\hline \multicolumn{2}{|c|}{ одни́ } & одн $\mathbf{6}^{\prime}$ \\
\hline $\begin{array}{l}\text { одा } \\
\text { од } \\
\text { одा }\end{array}$ & $\begin{array}{l}=\text { N. or } \\
\mathbf{X b} \\
\text { M' } \\
\text { Mи }\end{array}$ & 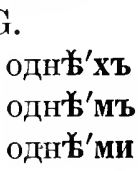 \\
\hline
\end{tabular}

Plural M. N. F.

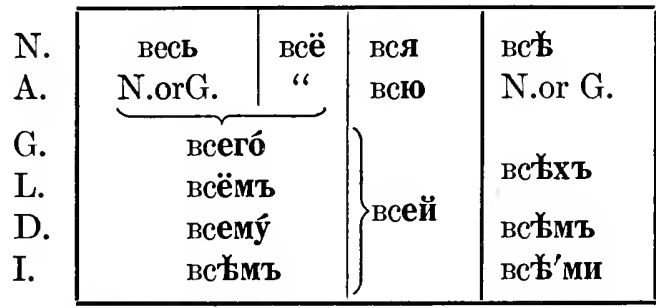

Са́мый, ка́ждый, вся́кій have regular adjective declension.

\section{The Adjective-Имя прелага́тельное}

Russian adjectives have either noun or pronoun endings. In the former case we speak of the predicative, in the latter, of the attributive forms of the adjective.

24. Predicative Declension:

Singular- $\left\{\begin{array}{l}\text { Онъ здоро́въ } \\ \text { Она́ здоро́ва } \\ \text { Оно́ здоро́во }\end{array} \quad\right.$ Они́ (онъъ`) здоро́вы-Plural 
The predicative endings of the adjectives are the same as those of the nominatives of hard nouns. The predicative forms of soft adjectives are rarely used.

A few adjectives have no predicative forms, namely: большо́й (вели́къ, -á, -ó, -и́ is sometimes used instead); adjectives in -скій and -ско́й, like pýcскій Russian, городско́й town-; adjectives denoting materials, like золото́ĭ golden.

Vowel Insertion generally takes place in the masc. sing. between two final consonants, but definite rules are not possible: чёренъ, черна́

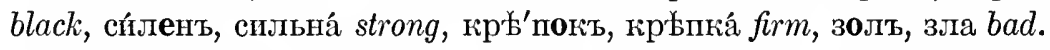

25. Attributive Declension. -This is originally a combination of the adjective with noun endings and the forms of the personal pronoun of the $3 \mathrm{~d}$ person, e.g., нова +его = но́ваго, нову +ему = но́вому.

With adjectives, as with nouns, we distinguish a hard and a soft declension. The endings of the nom. sing. are:

$\operatorname{HARD}\left\{\begin{array}{llll}\text { ый } & \text { ая } & \text { ое } \\ \text { ой̆ } & \text { áя } & \text { о́е }\end{array} \quad\right.$ SOFT: ій яя еe

Hard adjectives with accented endings have о̆й in the nom. sing. masc. and oro in the gen. sing. masc., and neut.

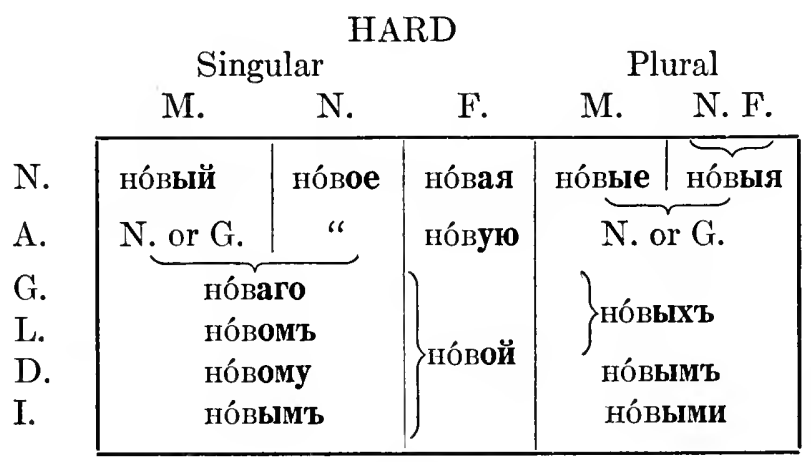

SOFT

\begin{tabular}{|c|c|c|c|}
\hline си́ній & сйнее & си́няя & си́ніе си́нія \\
\hline N. or G. & “ & си́нюю & N. or G. \\
\hline $\begin{array}{l}\text { cи́нs } \\
\text { си́не } \\
\text { си́не } \\
\text { си́н }\end{array}$ & & си́ней & $\begin{array}{l}\text { си́нихъ } \\
\text { си́нимъ } \\
\text { си́ними }\end{array}$ \\
\hline
\end{tabular}


$a$. The ending ro of the gen. sing. mase., neut. is pronounced [vo]. The nom. pl. of all three genders has the same pronunciation, namely [ыј $\mathbf{~ ] , ~ a l t h o u g h ~ t h e ~ s p e l l i n g ~}$ is be for the masculine and ыя for the feminine and neuter.-The nom. sing. masc. is pronounced [ыj] or [ы].

b. The instr. sing. fem. frequently shows the fuller form in ою-ею: но́вою.

c. The rules of vowel variation must be observed, e.g., хоро́шій, хоро́шая, хоро́шее, хоро́шіе; сла́дкій, сла́дкая, сла́дкое, сла́дкіе.

26. Possessive Adjectives (compare 28) have a mixed declension, in which some cases have noun endings, others, adjective endings.

These adjectives are formed:

1. From names of persons by changing the genitive ending $\mathbf{a}$ to $\mathbf{0 B \mathbf { b }}$, я to евт, ы-и to инт.

2. From names of animals in ій; also Бо́жій divine, from Божъ God, каза́чій cossack's from каза́къ, охо́тничій hunter's from охо́тникъ, and a few others.

\begin{tabular}{|c|c|c|c|c|}
\hline \multirow[t]{2}{*}{ • } & \multicolumn{3}{|c|}{ Singular } & \multirow[t]{2}{*}{ Plural } \\
\hline & M. & N. & F. & \\
\hline $\begin{array}{r}\text { Sing. N. } \\
\text { A. }\end{array}$ & $\begin{array}{l}\text { Па́вловъ } \\
=\text { N.or G. }\end{array}$ & $\begin{array}{c}\text { Па́влово } \\
\text { ، }\end{array}$ & $\begin{array}{l}\text { Па́влова } \\
\text { Па́влову }\end{array}$ & $\begin{array}{l}\text { Па́вловы } \\
=\mathrm{N} \text {. or G. }\end{array}$ \\
\hline $\begin{array}{l}\text { G. } \\
\text { L. } \\
\text { D. } \\
\text { I. }\end{array}$ & \multicolumn{2}{|c|}{$\begin{array}{l}\text { Па́влова } \\
\text { Па́вловомъ } \\
\text { Па́влову } \\
\text { Па́вловымъ }\end{array}$} & Па́вловой & $\begin{array}{l}\text { Па́вловыхъ } \\
\text { Па́вловымъ } \\
\text { Па́вловыми }\end{array}$ \\
\hline $\begin{array}{r}\text { Sing. N. } \\
\text { A. }\end{array}$ & $\begin{array}{l}\text { Бо́жій } \\
=\text { N.or G. }\end{array}$ & $\begin{array}{c}\text { Бо́жье } \\
\text { “ }\end{array}$ & $\begin{array}{l}\text { Бо́жья } \\
\text { Бо́жью }\end{array}$ & $\begin{array}{l}\text { Бо́жыи } \\
=\mathrm{N} \text {. or G. }\end{array}$ \\
\hline $\begin{array}{l}\text { G. } \\
\text { L. } \\
\text { D. } \\
\text { I. }\end{array}$ & $\begin{array}{l}\text { Бóis } \\
\text { Бóis } \\
\text { Бói } \\
\text { Бóis }\end{array}$ & $\begin{array}{l}\text { ьяго } \\
\text { ьемт } \\
\text { ьему } \\
\text { ьимъ }\end{array}$ & Бо́жьей & $\begin{array}{l}\text { Бо́жьихт } \\
\text { Бо́жьиимт } \\
\text { Бо́жьими }\end{array}$ \\
\hline
\end{tabular}

With some of these forms the usage is not quite settled; thus, the loc. sing. masc. Па́влов masc. Бо́жья, Ббжъю.

The patronymics that are derived from these possessive adjectives (Па́вловнчъ, Па́вловна), compare 58, have regular noun declension. 


\section{Comparison:}

A. The Predicative Comparative.

1. The regular form ends in łe: доббрый-добрь'е; краси́выйкраси́въе, сйльный-сильн'ъ'e.

2. Adjectives of more than three syllables use бóлře with the positive, e.g., образо́ванный educated-бо́лъ̌ образо́ванъ.

3. About forty adjectives have predicative comparatives in e or me; suffixes are often dropped in these forms, and final consonants are softened, e.g., páнній early-páньше, далёкій far-да́льше, высо́кій high-ви́ше, ста́рый old-ста́рше, молодо́й young-моло́же.

4. A few are irregular, e.g., хоро́шій good-лýчше, большо́й big 一бо́льше, ма́ленькій small-ме́ньше.

B. The Attributive Comparative.

In attributive function, the comparative is most frequently expressed by бо́л'se with the positive. But a number of adjectives form attributive comparatives corresponding to the regular predicative comparative; they end in -Һй шій (-aя, -ee) or - шій; -бйшій is changed to -aйшій after softened consonants (compare 50).

Instances:

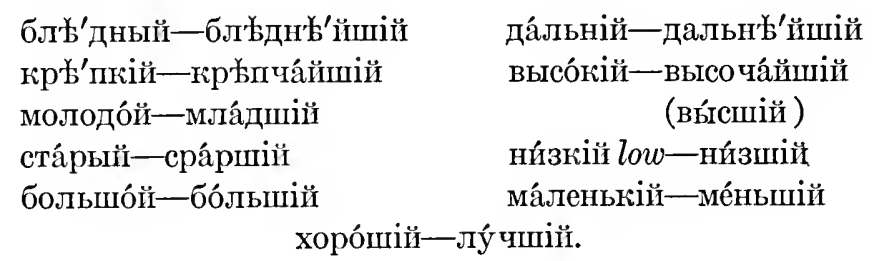

Rules are of little avail for the formation of the comparative; the forms in actual use must be ascertained by reading and reference to dictionaries.

C. THE SUPERLATIVE.

There is no special form for the superlative; it is expressed:

(a) By comparative forms; especially the attributive comparative in Łйшй, айшій has almost always comparative meaning.

(b) Ву самый with either the positive or the comparative: са́мый краси́вый most beautiful, са́мый лу́ чшій best.

(c) With a few adjectives, by the comparative with the prefix наII-, e.g., наилу́чшій best, наиббльшій biggest. 


\section{The NụmeraL-Имя числительное}

28. The Cardinals. -коли́ чественныя.

\begin{tabular}{|c|c|c|c|}
\hline 1 оди́нъ & 10 де́сять & 100 сто & 11 оди́ннадцать \\
\hline 2 два, двћ & 20 два́дцать & 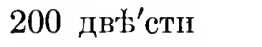 & 12 двъниа́дцать \\
\hline 3 три & 30 трі́дцать & 300 три́ста & 13 трина́дцать \\
\hline 4 четы́ре & 40 со́рокъ & 400 четь́реста & 14 четь́рннадцать \\
\hline 5 пять & 50 пятьдеся́тъ & 500 пятьсо́тъ & 15 пятна́дцать \\
\hline 6 шесть & 60 шестьдеся́тъ & 600 шестьсо́т' & 16 шестна́дцать \\
\hline 7 семь & 70 се́мьдесятъ & 700 семьсо́ть & 17 семна́дцать \\
\hline 8 во́семь & 80 во́семьдесять & 800 восемьсо́тъ & 18 восемна́дцать \\
\hline \multirow[t]{4}{*}{9 де́вять } & 90 девяно́сто & 900 девятьсо́тъ & 19 девятна́дцать \\
\hline & 21 два́дцать оди́нъ & 1000 ти́іс & \\
\hline & 32 три́дцать два, д & 2000 двъ & ги́сячии \\
\hline & 103 сто три & 5000 пят & ти́ся чъ \\
\hline
\end{tabular}

\section{DECLENSION:}

оди́нъ, see 23.

$2,3,4$ :

$\begin{array}{rcll} & \text { M.,N. F. } & \\ \text { N. } & \text { два двъ } & \text { три } & \text { четь́ре } \\ \text { A. } & =\text { N. or G. } & = & = \\ \text { G.L. } & \text { двухъ } & \text { трёхъ } & \text { четырёхъ } \\ \text { D. } & \text { двумъ } & \text { трёмъ } & \text { четырёмъ } \\ \text { I. } & \text { двумя́ } & \text { тремя́ } & \text { четырьмя́ }\end{array}$

Numbers in $\mathbf{b}$, ти́сяча, and милліо́нъ are declined like nouns with the same endings; $50,60,70,80$ have the same declension as пять, with the exception of the nominative and accusative, which end in $\mathbf{b}$ : пять-пяти́-пятью́; пятьдеся́тъ-пятйдесяти-пятью́десятыю;

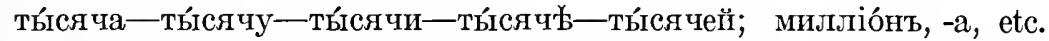

Со́рокъ, сто, девяно́сто generally have a in all oblique cases, but the dative (especially after the preposition no) often ends in $\mathbf{y}$.

Compound numbers (except 11-19) decline each element separately: $3333=\mathrm{N}$. три ты́сячи три́ста три́дцать три
G. трёхъ ти́сячъ трёхъсо́ть три́дцати трёхъ
D. трёмъ ты́сячамъ трёмстамъ три́дцати трёмъ, etc. 


\section{CONSTRUCTION:}

1. The counted noun stands in the genitive singular after the nominative and accusative of the numbers $2,3,4$, but in the genitive plural after all numbers from 5 up.

2. After numbers in oblique cases the noun stands in the same case as the number.

3. In the case of compound numbers the last element decides the form of the noun.

4. An adjective after a numeral agrees with its noun in number and case; but if the noun stands in the genitive singular, according to (1), the adjective may stand either in the nominative plural or the genitive plural.

\section{Instances:}

(1) два посль' 'дніе (посль'диихъ) дня the last two days

(2) пять посль'ь'днихт дней

(3) ти́сяча одна́ ночь 1001 nights (Arabian Nights).

29. The Ordinals. -порядко́выя.

1st пе́рвый

$2 \mathrm{~d}$ Bторóĭ

3d тре́тій

4th четвёртый

5th пя́тый

6th шестóii

7th седьмо́ї

8th восьмо́й

9th девя́тый 10th деся́тый

20th два́дцатый

30th' три́дцатый

40th сороково́й

50th пятидеся́тый

60th шестидеся́тый

70th семидеся́тый

80th восьмидеся́тый

90th девяно́стыї 100th со́тый

200th двухсо́тый

200th трехсо́тый

500th пятисо́тый

600th шестисо́тый

1000th тб́сячный

2000th двухти́сячный

21st два́дцать пе́рвый

32d три́дцать второ́й

The ordinals have regular adjective declension with the exception of тре́тій, which is declined like Божіій, 26. 


\section{The Preposition-Предлóгъ}

30. Prepositions may require one, two, or three cases, as shown in the following diagram:

Dat. Loc.

Acc. $\quad$ Instr.

Gen.

\begin{tabular}{|c|c|c|c|c|c|}
\hline $\begin{array}{l}\text { One } \\
\text { case }\end{array}$ & къ & при & про, че́резъ, сквозь & надъ & $\begin{array}{c}\text { безъ, для, до, } \\
\text { изъ, отъ, y }\end{array}$ \\
\hline \multirow{2}{*}{$\begin{array}{l}\text { Two } \\
\text { cases }\end{array}$} & & & 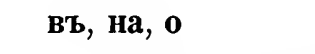 & & ме́жду \\
\hline & & & \multicolumn{2}{|c|}{ за, подъ, пе́редъ } & . \\
\hline \multirow{2}{*}{$\begin{array}{c}\text { Three } \\
\text { cases }\end{array}$} & \multicolumn{3}{|r|}{ по } & & \\
\hline & & & \multicolumn{3}{|c|}{ ç } \\
\hline
\end{tabular}

Besides, the genitive is required by practically all prepositional adverbs, i.e., prepositions which are derived from other parts of speech, chiefly from nouns (e.g., вм'b'cто in place of, instead).

Alphabetical List, including prepositional adverbs:

\begin{tabular}{|c|c|c|c|}
\hline безъ & G. without & на & A., L. on, upon \\
\hline лизь & G. near & - надъ (на́до) & I. above, over \\
\hline доль & G. down & o (объ, о́бо) & A. against, L. about \\
\hline и'сто & G. instead & о́коло . & G. around \\
\hline нутри́ & G. within & - отъ (о́то) & G. from \\
\hline H't & G. outside of & пе́редъ (предъ, & пре́до) А., I. in front of \\
\hline во́зль' & $\begin{array}{l}\text { alongside of } \\
\text { G. around }\end{array}$ & $\begin{array}{l}\text { - по } \\
\text { по́сль }\end{array}$ & $\begin{array}{l}\text { A. up to, L. after, D. on } \\
\text { G. after }\end{array}$ \\
\hline b (во) & A. into, L. in & подъ (по́до) & A., I. under \\
\hline ля & G. for & при & L. at, near \\
\hline & G. up to, until & про & A. about \\
\hline & A., I. behind, for & про́тивь & G. against \\
\hline & G. out of & ра́ди & G. for the sake of \\
\hline & G. besides & среди́ & G. in the midst of \\
\hline$b(\mathrm{ko})$ & D. to & съ (co) & G. from, A. up to, I. with \\
\hline е́жду & I., G. between & & G. at, with \\
\hline ймо & G. past & че́резъ (чрезъ) & A. through, across. \\
\hline
\end{tabular}

Note: If the following word begins with several consonants, $-\mathrm{z}$ is usually replaced by o, e.g., со мнб́ю, пре́до мнб́ю, по́до мнбю; the preposition o has the form объ before vowels (объ этомъ), ббо before consonant groups (ббо мнъ). 


\section{CONJUGATION-CIPЯЖEHIE}

\section{The Verb-Глаго́лъ.}

31. The Two Conjugations:

$$
\text { д'ъ'лать Infinitive }
$$

\section{Present}

Sing. 1. дь'лаю

2. ди' лаешь

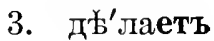

Plur. 2. дй'заемъ

1. дъ'лаете

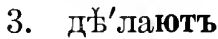

говори́ть

говори́ говори́ шь говори́ть говори́мъ говори́те говор я́т дъ́⿱宀⿻и一 Imperative дъ'зайте говорй говори́те

Past
дњъ'лалъ, a, о, и $\quad$ говорйлъ, a, o, и

\section{The First Conjugation:}

A. Vocalic Class.

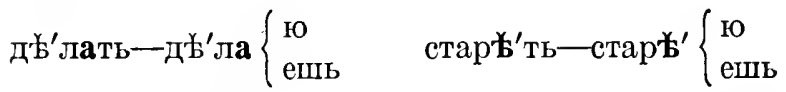

$$
\begin{aligned}
& \text { дава́ть一да }\left\{\begin{array}{l}
\text { о́ } \\
\text { ёшь }
\end{array}\right. \\
& \text { крыть-кро́ }\left\{\begin{array} { l } 
{ ю } \\
{ \text { ешь } }
\end{array} \text { пить-пь } \left\{\begin{array}{l}
ю \\
\text { ёшь }
\end{array}\right.\right.
\end{aligned}
$$

B. Consonantic Class.

(1) Without Consonant Softening.

$$
\begin{array}{ll}
\text { класть-клад }\left\{\begin{array}{l}
\hat{y} \\
\text { ёшь }
\end{array}\right. & \text { нести́-нес }\left\{\begin{array}{l}
\mathbf{y} \\
\text { ёшь }
\end{array}\right. \\
\text { везтй-вез }\left\{\begin{array}{l}
\hat{y} \\
\text { ёшь }
\end{array}\right. & \text { стать-ста́н }\left\{\begin{array}{l}
\text { ешш } \\
\text { ешь }
\end{array}\right. \\
\text { брать-бер }\left\{\begin{array}{l}
\hat{y} \\
\text { ёшь }
\end{array}\right. & \text { верну́ть-верн }\left\{\begin{array}{l}
\hat{y} \\
\ddot{~ е ̈ ш ь ~}
\end{array}\right.
\end{array}
$$


(2) With Consonant Softening.

a. In all persons:

пис-а́ть-пп шу́, пи́ шешь, пи́ шетъ; пи́ шемъ, пи́ шете, пи́ шутъ. каз-а́ть-кажу́, ка́жешь, ка́жетъ; ка́жемъ, ка́жете, ка́жутъ. сл-ать-шлю, шлёшь, шлётъ; шлёмъ, шлёте, шлютъ.

b. In the four middle persons only:

мочь-могу́-мо́жешь, мо́жетъ; мо́жемъ, мо́жете-мо́гутъ. течь-теку́—течёшь, течётъ; течёмъ, течёте-теку́тъ.

\section{The Second Conjugation:}

(1) Without Consonant Softening:

$$
\begin{aligned}
& \text { говорйть-говор }\left\{\begin{array} { l } 
{ \text { б́ } } \\
{ \text { и́ шь } }
\end{array} \text { держа́ть-держ } \left\{\begin{array}{l}
y ́ \\
\text { ишь }
\end{array}\right.\right. \\
& \text { смотрб'ть'т-смотр }\left\{\begin{array}{l}
\text { ю́ } \\
\text { ишь }
\end{array}\right.
\end{aligned}
$$

(2) With Consonant Softening-first person only.

$$
\begin{aligned}
& \text { вози́ть- }\left\{\begin{array} { l } 
{ \text { вожу́ } } \\
{ \text { во́дишь } }
\end{array} \text { ви́д安ть- } \left\{\begin{array}{l}
\text { ви́жу } \\
\text { ви́дишь }
\end{array}\right.\right.
\end{aligned}
$$

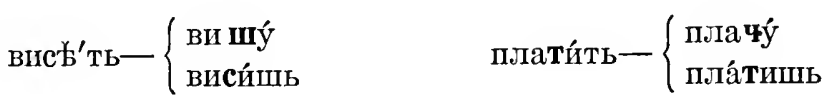

$$
\begin{aligned}
& \text { спать- }\left\{\begin{array}{l}
\text { сплю } \\
\text { спишь }
\end{array}\right.
\end{aligned}
$$

\section{Irregular Presents :}

1. Vowel Insertion: звать-зови́, брать-беру́.

2. Vowel Omission: жечь-жгу, -мере́ть-мру.

3. Vowel Change: лечь-ля́гу, крыть-кро́ю.

4. Nasal Insertion: стать-ста́ну.

5. Insertion of в: жить-живу́.

6. Omission of в: дава́ть-дать.

7. Mixed Conjugation: бъжа́ть一бЊгý, бъжи́шь, бъжи́тъ; бЊжиимъ, бъжи́те, бЊгу́тъ.

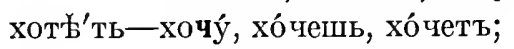
хотймъ, хоти́те, хот я́тъ.

8. Anomalous: быть, дать, Łеть一see $59 h$. 


\section{The Imperative:}

1. Full ending: и́, и́те: идй, иди́те; говорй, говори́те.

2. Weakened ending, if unaccented:

a. After consonants, ь, ьте: бу́дь, бу́дьте.

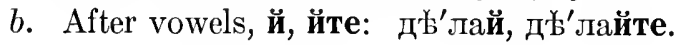

\section{The Infinitive:}

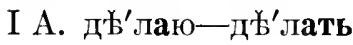
пожа́лую一пожа́ловать при́гтн-при́г гуть кро́ю-крыть даю́-дава́ть.

I B. (a) пи шý-писа́ть, мечý-мета́ть

(b) зову́-звать, беру́-брать

(c) паду́- пасть

(d) могу́-мочь.

II. (a) говори́ть, учи́ть

(b) держа́ть, сль́ шать

(c) смотры'ть, ви́дъть.

37. The Past Tense:

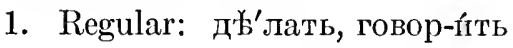
“ -

2. Verbs in чь, зть, зти, сть, сти: мо чь-могъ (могла́, могло́, могли́) нести́-нёсъ (несла́, несло́, несли́).

3. Verbs in сти, сть with stems in д, т:

$$
\begin{aligned}
& \text { ведý, вести́-вёль (вела́, вело́, вели́) } \\
& \text { паду́, пасть-палъ (па́ла, па́ло, па́ли). }
\end{aligned}
$$

\section{The Verbal Adjectives:}

Present Gerund: д д'委ла-[ютъ], говор-[я́тъ]

$$
\text { " -я "-я́ }
$$

Present Active Participle: дъъ'ла-[ютъ], говор-[я́тъ] -ющій “ -я́ щій.

Present Passive Participle: дъ'ла-[емъ], лю́б-[имъ]

$$
\text { " -емый "-и́мый. }
$$

Past Gerund: д'委ла-[лъ], полюби-[лъ] 
Past Active Participle: д д'ъ'ла-в шій, полюбі́в шій.

Past Passive Participle: д'犬'

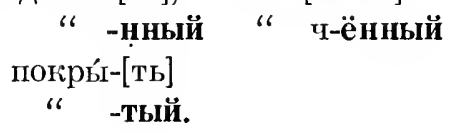

39. Perfective and Imperfective Aspect:

A. The Perfective is derived from the Imperfective Aspect by a prefix:

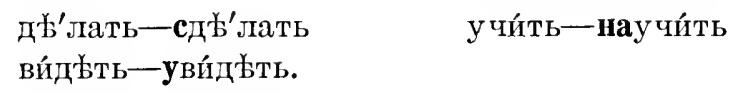

B. The Imperfective is derived from the Perfective by stem variation:

1. Compound Verbs:

a. By Suffix:

открыва́ть from откри́ть; прнду́мывать from приду́мать; науча́ть from научи́ть.

b. By Change of the Stem Vowel:

собира́ть from собра́ть, соберу́ посыла́ть “ посла́ть, пошлю́.

2. Simple Verbs:

a. Stem Lengthening:

дъва́ть from д它ть; станови́ться from стать; па́дать from пасть.

b. ать for ить ог нуть:

пуска́ть from пусти́ть; крича́ть from крі́кнуть.

40. Definite and Indefinite Aspect.

ходи́ть be in the habit of going-итти́ be on the way носи́ть wear (as a rule)-нести́ carry, wear (at present) води́ть be a guide (in general)-вести́ lead to a place. 



\section{VOCABULARIES}





\section{VOCABULARIES FOR TEXTS I-VIII}

I

ІІко́ла school.

э́тоть, э́та, э́то this.

комната room.

пппро́къ, á, ó wide.

высо́къ, á, ó high.

I and.

окно́ window.

потоло́къ ceiling.

воть here (there) is.

вон's there is.

ка́фқедра (teacher's) desk.

стуль chair.

шкапъ cupboard.

полт floor.

доска́ board, blackboard.

па́лка stick, pointer.

жёлть; желта́, жіёлто yellow.

тó́ze also.

каранда́ш'ь pencil.

nерó pen.

но́жiık's penknife.

a and, but (weak adversative conjunction).

но but (strong adv. conj.).

чёренъ, черна́, чёрно black.

мой my.

тупъ, á, ó dull, blunt.

остёръ, остра́, остро́ sharp.

бума́га paper.

гла́докъ, гладка́, гла́дко smooth вопро́сь question.

что what.

како́въ, á, ó of what kind

онъ, она́, оно́ he, she, it.
II

У чи́лнце school.

больпо́ї big.

зда́ніе building.

Í⿴囗十I or.

я I.

учи́тель teacher.

ймя first name.

фами́лія family name.

вы you.

у чепи́къ student (masc.).

учени́rцa student ( $\mathrm{fem}$.).

y ý́ I teach.

вы у́ чптесь уоu learn, studly.

вы хоти́те you want to.

пзу ча́ть learn, study.

pýccriĭr Russian.

язи́к'ь language.

кни́га book.

грамма́тига grammar.

а́нглійскіӥ English.

слова́pь dictionary.

тónkiї (то́нокъ, тонкá) thin.

лёгкій (лёгокъ, лекка́, ó) light.

вашъ уоur, нашъ our.

тетра́дь, fem. notebook.

ма́ленькій small.

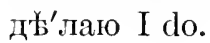

дъ' лаете уŏ do.

лII interrogative particle.

но̆ть nо, да уеs.

тяжіёлый (-ёлъ, -ела́, ó) heavy.

кто who.

который which.

kake how (what). 
III

Говориі́ть speak.

по-ру́cciı (in) Russian.

He not.

по-áıглійçıı (in) English.

слу́шать listen.

cпр́́muвats ask.

отв Вับа́ть answer.

на́до (it is) necessary, (one) must.

nо чTí almost.

вceritá always.

criópo fast, soon.

ме́дленно slow.

е́лाI if.

понима́ть understand.

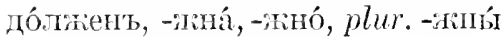
compelled, must.

когда́ when, тогдá then.

обълепи́ть explain.

пожи́луйста please.

пlaёть he gives.

oōъsсне́nie explanation.

б.тагодари́ть thank.

вас'ь you (acc.), nans us (dat.).

rmacíno thanks.

ypók lesson.

тру́дныї diffieult.

оччень very.

тінта́ть I'cal.

ка́ждый each, every.

rácro often.

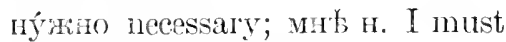
nереводи́ть translate.

To that.

Teneps now.

пропззоле́xic pronunciation.

Iñóxî̀ bar.

буддеть' will be.

xорóminĭ (-э́แт, á, ó) good.

пото́w then.
IV

Вещь, fem. thing. $\mathrm{Bъ}(w . l o c$.$) in.$ столь table.

гла́ссный class-.

II такъ да́л’’e and so forth.

на $(w . l o c$.$) upon.$

я́щикъ box, drawer.

мّ้ль chalk.

спди́т he is sitting.

гре́сло armchair.

crmý I am sitting.

cкaмéïka bench.

Iтросто́ï plain.

встаёть he gets up.

пдёть he goes.

i`s (w. dat.) to.

де́ржіпाт he holds.

pyriá hand.

пи́шеть he writes.

бъ'лый white.

пежи́́т ь lies.

свой his.

cтои́т' stands.

одно́мъ loc. of оді́н'ъ one.

у́голь, loc. (въ) углу́ corner.

припадлежкі́ть belongs.

прихо́димъ we come.

другъ friend.

здра́ветвуйте how are you

(lit., be in good health).

yхо́дпм's we go away.

до свпда́пія goodbye (au revoir).

проца́̆те goodbye.

піудá where, whither.

гдf where.

rosý to whom. 
Писáнie writing. нача́ло beginning. вызыва́ть call out. во́зль্' (w.gen.) alongside, near. открыва́ть open. вслухъ aloud. отвњ'тъ answer. оши́бка mistake. поправля́ть correct. eë her $(a c c$.$) .$ опя́ть again. закрыва́ть close. но́вый new.

безъ (w. gen.) without. $\mathrm{y}(w . g e n$.$) with, at.$ y че́бникъ textbook. у учйтеля the teacher has. вм'ъ'сто (w. gen.) instead of. вынима́ть take out. изъ $(w . g e n$.$) out of.$ кладёмъ we put, lay. пра́вый right. ль'з'вый left.

у меня́ I have. карма́нъ pocket. чиню́ I sharpen. загла́вie title. y koró who has. неѓ́, неи́ for eró, ея́ (gen. of онъ, она́) after prepositions. есть is.

чเัБмъ instr. of что. $\mathrm{y}^{\prime}$ тро morning. обыкнове́нно usually. встаю́ I get up. шесть six. ... . часо́въ o'clock. ва́нная bathroom. купа́ться bathe. мыться (1st p. м о́юь) wash (one's self).

холо́дный cold. вода́ water.

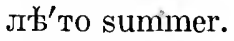
тёплый warm. зимá winter. чи́щу (inf. чисти́ть) clean. зубъ tooth. зубна́я щёточка toothbrush. пью (inf. пить) drink. стака́нъ glass. чи́стый clean. бр'ъ'юсь, бре́юсь (inf. бри́ться) shave.

безопа́сная бритва́ safety razor. причёсывать comb. во́лосъ hair. головна́я щётка hairbrush. ме́жду ть̌ъъ meanwhile. пе́редъ $(w$. instr.) in front of, before.

кру́глый round. зе́ркало mirror. виси́ть is hanging. crờruá wall. одъвва́ться dress, put on. 
спа́тьня bedroom.

pyбáxa shirt.

воротни́къ collar.

въ о́бцемъ altogether.

туале́тъ toilet.

продолжа́ется lasts, takes.

у меня́ with me.

полчаса́ half an hour.

по́сль (w. gen.) after.

захожу́ I go.

столо́вая dining-room.

сажу́сь I sit down.

за (w. instr. and acc.) behind, for.

за́втракъ breakfast.

eщё yet.

гото́вый ready.

у́тренній morning-.

газе́та newspaper.

ча́шка cup.

молоко́ milk.

горя́ чій hot.

чай tea.

два two.

ъсть еat, $59 h$.

яйца́ $\operatorname{egg}(\mathrm{s})$.

кусо́къ рiece.

хльбб bread.

съ (w. instr.) with.

мácло butter.

cáxapъ sugar.

люблю́ I love, like.

сла́дкій sweet.

сперва́ first.

зать' мъ after that, then.

какóï what kind.

ско́лько вре́мени how much time,

how long.

ку́шать eat.

почемý why.

потому́ что because.

Домъ house.
состойтъ consists.
кри́ша roof.
го́родъ city.
мно́го (w. gen.) many.

въ три (четь́ре) этажа́ of three

(four) floors.

эта́жъ floor.

кварти́pa dwelling, apartment.

нахо́дится is situated.

вторóĭ second.

неї loc. sing. of она́.

сль'дующіе the following.

гости́ная, пріёмная reception

room, parlor.

кýхня kitchen.

прннима́ть receive.

гость guest.

устла́нъ is covered.

ковёръ carpet.

прекра́сный beautiful.

карти́на picture.

спятъ they sleep.

дю́ли people:

стои́ть they stand.

крова́ть, fem. bed.

комо́дъ bureau, dresser.

приготовля́ть prepare.

кýшанье food.

съъстни́е припа́сы victuals.

храни́ть keep, store.

кладова́я pantry, larder.

по́гребъ cellar.

за́втракать eat breakfast.

объ'дать eat dinner.

ужжинать eat supper.

о́коло (w. gen.) around.

нъ'сколько several, a few.

покри́ть covered.

ска́терть tablecloth. 
таре́лка plate.

ножь knife.

ви́кла fork.

ло́жка spoon.

ло́жечка teaspoon.

салфе́тка napkin.

'Бди́мъ we eat.

супъ soup.

ми́co meat.

пьёмъ we drink. róde coffee.

садъ garden.

дс́рево, $p l$. дере́вья tree.

по́сль' (w.gen.) after.

гуля́ть take a walk.

тъни́стый sharly.

доро́га walk, way.

чего́ gen. of что.

для (w. gen.) for.

слу́жить serves.

\section{VIII}

Раздъиле́ніе division.

вре́мя time.

раздъиля́ть divide.

годъ year.

м'ь'сяцъ month.

назва́ніе name.

день, gen. дня day.

остально́й remaining, other.

составля́ть form.

нед'安'ля week.

пе́рвый first.

день пра́здничный holiday. paбó чій (день), бу́день week day. отдыха́ть rest.

отъ (w. gen.) from. весна́ spring.

начнна́ться begin.

стиль, masc. style, calendar.

но́вый new

ста́рый old.

осень, fem. autumn.

часъ hour; два часá two o’clock

мину́та minute.

полови́на half

число́ number, date.

сего́дня today.

ихъ gen.-acc. pl. of онъ, она́, оно́

o (w. loc.) about, for.

тако́ĭ such.

называ́ться be called. 


\section{LESSON XXXVII}

The words in this lesson are not included in the General Vocabulary.

Гла́вный principal, first. ви́игришъ prize, winner. счастли́вецъ lucky fellow. бо́лŁ̌e more.

crópa quarrel, dispute. открове́нно openly, frankly. узна́ть learn, find out. двухсо́тъ-ть́сячный of 200,000 , i.e., 200,000 rubles' worth. биле́тъ ticket.

достовъ'рный, superlative досто-

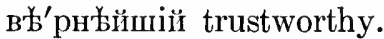
разска́зъ story, report. сообще́ніе information. найдётся will be found. пойди́ go! разбери́ select, find out! пра́вда truth. живёть lives. тот' that. арте́льщикъ (union) workman. писа́рь writer.

биржеви́къ speculator. столя́ръ cabinet-maker. моло́чица milkmaid. сапо́жнииъ shoemaker. купе́цъ merchant. реме́сленникъ artisan. ямцци́къ driver, drayman. куха́pка cook (fem.). бу́лочникъ baker. худо́жникъ artist. чино́вникъ official. пра́порщикъ ensign. поэ́тъ poet. жена́ woman, wife. дьячёкъ sexton. дочь daughter. букини́стъ dealer in old books. коро́че, сотр. of коро́ткій, short (in short, briefly). лицо́ face, person. назову́тъ they will name. 


\section{GENERAL VOCABULARY}

\section{NOTES}

References.-Bold-face figures refer to the sections of Part One, lightace figures preceded by $\uparrow$, to the sections of Part Two.

Pronunciation.-For phonetic transcription, see 5, 6, 10, 16, 17, 20, and If 3 and 94.

ACCENT.-The accent of primary forms (nom. sing. of nouns, inf. of verbs) is indicated by bold-face vowels in the transcription. Mobile accent is indicated for those forms that vary from the accent of the primary form, either by an accented ending, or by an acute preceded or followed by a dash, e.g.:

былъ, á: the feminine accents the ending, the other forms, like the masc. sing., the stem;

волкъ, g-ip.-': the singular and the nom. pl. have the accent on the stem, but gen. to instr. pl. accent the ending;

де́рево, $p l$. - '-: the singular stresses the first, the plural the second, syllable.

Nouns.-ns., gs., $d p$. ., ip., etc.: nom. sing., gen. sing., dat. pl., instr. pl., etc. The gender is indicated by $m$. or $f$. in the case of nouns in $ь$; with all other nouns it follows from 22 and $\uparrow 7$.

ADJECTIVEs. - pr.: predicative form, $c p .:$ comparative.

VerBs.-The two aspects are separated by a dash, the imperfective aspect preceding in every case. The past tense is stated if formation or accent are irregular.

A [a] and, but.

авось [avos] maybe.

аль [аl] interrog. particle.

англійскій [angliskыј] English.

Баба [baba] (peasant-)woman.

баранъ [baran] ram.

бари нъ [barin] gentleman.

безопасный [bizapasnыj] without danger; б-ая бри́тва, safety razor.

безъ $[b \varepsilon \mathrm{s}$, bis] prep. w. gen. without.

бить $\left[b \mathbf{i} t^{\prime}\right]$ бью, оьёшь-по- beat.

благодарить [blaradari $t^{t}$ ] -рю́, -ри́шь -no- thank.

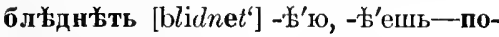
turn pale.

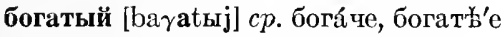
rich.

Богъ [box] voc. Бо́же, ๆ 8, God.
Божій [bоžïj] ๆ 26, God's, divine.

бой [boj] fight.

больть [bale $\left.t^{\prime}\right]$ - '⿳⺈, -б'ешь一за- be or become sick.

боль шой [balšoj] $c p$. бо́льшій, $a d v . c p$.

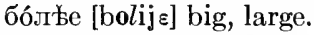

бояться [bajatsa] бою́сь, бойшься-поbe afraid.

opara [braga] fight.

брать [brat'] беру́, -рёшь-взять [vzat $\left.t^{6}\right]$ возьму́, -мёшь; взяль, -á, take.

бритва [britva] razor.

брить [brit $\left.t^{\prime}\right]$ бре́юсь, -е́ень-ви́- shave. будень [budin] gen. -дня week day.

буду, see быть.

бумага [bumaga] paper.

бу шевать [bušĩva $t^{\prime}$ ] -пу́ю, -шýешь3a- howl, roar.

буфетъ [bufet] sideboard. 
бывать [bыvat'] -áю, -áeшь-по- visit.

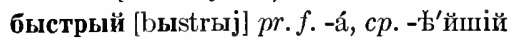
fast, rapid.

быть [bыt $\left.t^{t}\right]$ бу́ду, -дешь, 59 , (былъ, á, o) be.

бъгать [bعgat $\left.{ }^{\prime}\right]$-аю, -аешь-nо- run.

бъда [bida] need, misery.

бъдный [bعdnыj] poor.

бъжать $\left[b \mathrm{iža} t^{\prime}\right]$ бъгу́, -жи́шь-по- run.

бълка [bعlka] squirrel.

бұлый [bعlыј] pr. $f$. -á, white.

Ванная [vannaja] adj. decl. bathroom. васъ [vas] acc. of вы you.

ва шъ [vaš] your.

вверxy [virxu] above, up there.

везти [visti] вези́, -зёшь; вёзъ, везла́, ó

-no- convey, carry (on a wagon).

великій [vilikыj] $p r . f$. -á, great.

веселый [visoldj] $p r .{ }^{\prime}-, f$. -á, $c p$. - ‘'e, merry, happy.

весна [visna] $p l$. '- (вёсны) spring.

вести [visti] ведý, -дёшь; вёлъ, á, ó, и́ lead, guide.

весь, вся, всё $[v e s, \mathrm{f} s \mathbf{a}, \mathrm{f} s \mathbf{c}]$ all.

вечеръ [večir] $p l$. —', -á, evening.

ве щь $[v \mathbf{e} s ̌ c] f ., g-i p$. - $^{\prime}$ thing, object.

вздорт [vzdor] nonsense.

вида́ть $\left[v i d a t^{\prime}\right]$-а́ю, -аешь-y- see.

видт [vit] sight, look.

видьть $\left[v \mathbf{i} d \mathrm{i} t^{\prime}\right]$ ви́жу, -дишь-у- see.

вилка [vilka] fork.

винить $\left[v i n i t^{\prime}\right]$-ню́, -ни́шь-объ- blame. висъть [vise $t^{6}$ ] вишу́, -си́шь-пови́с-

иуть, -ну, -нешь hang (up).

вльво [vlıvo] on the left.

вмбсто [vmعsto] prep. w. gen. instead.

в нимать [vnimat $\left.t^{\prime}\right]$-áю, -а́ешь一внять, вниму́, -мёшь hear.

вода [vada] as., $n p$. '- water.

водить [vadit'] -жу́, 'дишь-no- guide.

воеть, see выть.

возить [vazi $\left.t^{\prime}\right]$-жу́, 'зишь-по- convey.

возль [vozls] prep. w. gen. near, at.

возъ [vos] load.

война [vajna] $p l$. ' - war.

войти, see входи́ть.

волкъ [volk] $g$-ip. - ' wolf. волосъ [volas] $p l$. -á or -ы, $d-i p .-^{\prime}$ hair.

вонт [von] there (is).

вопросъ [vapros] question.

ворота [varota, varata] neut. $p l$. gate.

воротникъ [varatnik] - ' collar.

воскресенье [vaskrise $n \varepsilon$ ] Sunday.

воть [vot] there (is).

впадать [fpada $t^{\prime}$ ] -а́ю, -а́ешь一впасть

-ду́, -дёшь (впаль) fall (into).

вполнъ [fpal $n \varepsilon$ ] entirely.

вправду [fpravdu] truly, indeed.

вправо [fpravo] to the right.

врагъ [vrak] -' enemy.

время [vrema] $\uparrow 13$, time.

Bcë [fso] everything, all.

всегда [f $s i \gamma$ da] always.

вскакивать [fskakivat'] -аю, -аешьвскочить [fskačit'] -чý, 'чншь jump up.

вслухъ [fslux] aloud.

вставать [fstava $t^{\prime}$ ] встаю́, -ёшь-встать вста́ну, -нешь, stand up, get up.

встр‡ чаться [fstričatsa] -áюсь, -áешься -встрџ'титься, 'чусь, 'тишься mеet. вс- $[\mathrm{f} s \varepsilon] p l$. of весь all.

всякій [fsakыj] each, every.

второй [ftaroj] second.

входить [fxadit'] -жќ́, 'дишь-войти

[vajti] войдý, -дёшь (вошёлъ, -шла́) go in, enter.

Въ $[\mathrm{v}, \mathrm{f}]$ prep. w. dat. and acc. in, into. выводить [vыva $d \mathbf{i} t^{\prime}$ ] -жу́, 'дишь-ви́вести [vыvisti] вы́веду, -дешь (-велъ) lead out.

выздоравливать [vыzdaravlivat'] -аю, -аешь-ви́здоровъть [vыzdaravit'], -Ђю, -Һешь recover.

вызывать [vыzыvat'] -а́ю, -а́ешь-вы́звать [vыzvat'] -зову, -вешь, call out.

выльчивать [vыlečivat'] -аю, -аешьвб́л

вынимать [vыnimat $t^{\prime}$ ] -а́ю, -а́ешьви́нуть [vыnut $t^{\prime}$ ] -ну, -нешь take out. выноси́ть [vыnasi $t^{t}$ ] -шý, 'сншь-ви́нести [уы $n$ isti] -cy, -сешь carry out. высокійі [vыsokыj] $p r .-^{\prime}, c p$. ви́ше, вы́сшій high. 
выть [vы $\left.t^{t}\right]$ во́ю, во́ешь-вз- roar.

выъзжать [vыjižat'] -жа́ю, -а́епьви́ґхать [vыjixat'] 'Һду, 'Һдешь ride, drive out.

въдь $\left[v t^{*}\right]$ indeed.

в Һрить [verit $\left.t^{\prime}\right]$ 'рю, 'рншь-по- believe.

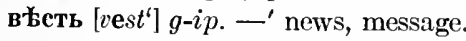
вътвь [vetf] $f$., $g$-ip. - ' branch. вътеръ [vetir] $p l$. -тра́, 'тры, wind. вътка [vetka] branch, twig.

Газета [gazzta] newspaper.

гдर्ठ $[\gamma d \varepsilon]$ where.

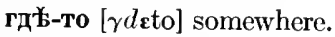

герой [giroj] hero.

гибнуть [gibnut $\left.t^{*}\right]$-ну, -нешь-поdestroy.

гладкій [glatkыj] $p r . f$. -á, $c p$. гла́же, smooth.

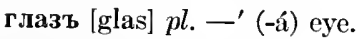

глубокій [glubokыj] $p r .-^{\prime}, c p$. глу́бже deep.

глупый [glupыj] pr.f. -á, stupid.

глядъть [glidet'] -жý, -ди́шь-no-look. гнать [gna $t^{\prime}$ ] гоню́, го́нишь-no- chase. говори́ть [gavarit'] -рю́, -ри́птъ-сказа́ть, скажу́, ска́жешь say.

годъ [got] $p l$. -á or -ы, $g-i p .--^{\prime}$, year. голова [galava] as., np.'-, head.

головной [galavnoj] head-.

голодный [galodnыj] cp. -Һ'e, hungry.

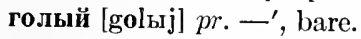

гончій [gončij] adj. decl. hound.

rope [gor $\varepsilon$ ] misfortune.

городъ [gorat] $p l .-^{\prime}$, -á, eity.

горячій [garačij] $p r .-^{\prime}, c p$. - f'e, hot. гостиная [gastinaja] adj. decl. parlor.

гость [gost'] $g$-ip. - ', guest.

готовый [gatovыj] ready.

грамматика [gramatika] grammar. грамота [gramata] alphabet, reading. гребень [grebin] gen. -бня, comb. гроб̄ъ [grop] $p l .-$ ', -б́ or -á, grave. гулять [gulat'] -я́ю, -я́ешь-по- walk.

IIa [da] yes.

давать [dava $t^{\prime}$ ] даю́, даёшь-дать [dat $\left.t^{\prime}\right]$ дамъ, дашь, $59 h$, цалъ, á, о, и, give давно [davno] long ago, 52. даже [daž $є]$ even.

далёкій [dalokыj] pr. -', cp. да́лЊе, да́льше, far.

двое [dvoj $\varepsilon$ ] two (together).

день $[d \mathbf{e} n] m$. , gen. дня, day.

деньги [dengi] m. pl. money.

деревня [direvna] gp. -венъ, $d-i p .-{ }^{\prime}$, village.

дерево [derivo] $p l .-^{\prime}-, n p$. дере́вья, tree.

держать [diržat'] -жу́, 'жишь-поhold.

дитя [dita] 13, ehild.

для $\left[d l \mathbf{a}, d l_{\mathrm{I}}\right]$ prep. $w$. gen. for.

до [do, da] prep. w. gen. to, until.

добрый [dobrыj] $c p$. добрњ'е, ду́чше, pr. -', good.

дождь [došt $\left.t^{\prime}\right]-{ }^{\prime}$, rain.

долгій [dolgыj] cp. до́льше, должа́йшінй, до́лће, long.

долгъ [dolk] $p l .{ }^{\prime}$ 'debt.

должент [dolžïn] -жна́, ó, í obliged, compelled (must).

доль [dol] dale, valley.

дома [doma] at home.

домъ [dom] -', np. дома́, house.

дорога [doroga] way.

дорогой [daragoj] pr. f. -', dear, $c p$. доро́же, дорожа́йшій.

доска [daska] as., np. '- blackboard.

дочь [doč] 13 daughter.

доъзжать [dajiža $t^{s}$ ] -а́ю, -а́ешь,一доъ-

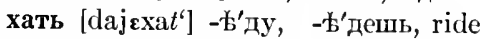
drive (through, to the end).

драка [draka] fight.

драть [drat'] церý, -рёшь-раз-, соtear to pieces, kill.

дрова [drava] wood, lumber.

дрожать [dražat $t^{6}$-жý, -жíшь-за-

tremble.

другой [drugoj] other.

другъ [druk] $p l .-^{\prime}, n p$. друзья́ friend.

дуракъ [durak] -' fool.

дума [duma] thought, meditation.

думать [dumat'] -аю, -аешь-по- think.

ду ша [duša] as., np. '- soul.

дъвочка [devačka] girl.

дъдъ $[d \varepsilon t]$ grandfather. 
дълать [delat'] 'аю, 'аешь-с- do. дъло $[d \varepsilon l o] p l$. - ' work, act.

на са́момъ ды'ль in fact, really. дъти [deti], see дитя́.

Если [jesli] if. е щё [jiščo] still, yet.

Жаль [žal] sad, regrettable; мнъ жаль, w. gen., I am sorry.

жать [žat'] жнну, ёшь-c- cut, harvest. ждать [ždat'] жғду, 一ёшь., w. gen. expect.

же [žs] emphatic particle.

желать [žïlat $\left.t^{\prime}\right]$-áю, -а́епь-по- wish. жёлтый [žoltыj] pr.f. -' yellow. жена [žïna] $p l . '$ - (жёны) woman. жертва [žrrtva] victim.

жечь [žес̌] жгу, жжёшъ (жёгъ, жгла) -c- burn.

животъ [žìvot] $\sim^{\prime}$ life.

жить [žï $\left.t^{t}\right]$ жіиву́, -вёшь (жилъ, á, o, и) no- live.

3a [za] prep. acc. or instr. behind, for. забольть, sеe больть.

заборъ [zabor] fence.

забъгать [zabigat'] -а́ю, -а́ешь-забłжать [zabižat $\left.t^{\prime}\right]$-гу́, -жи́шь, make a call.

завтракать [zaftrakat'] take breakfast. завтракъ [zaftrak] breakfast.

забывать [zabыvat $t^{\prime}$ ] -а́ю, а́ешь,一за-

быть [zabыt'] -бу́ду, 'дешь, forget. заглавіе [zaglavijє] title.

запоръ [[zapor] bolt, lock.

закрывать [zakrыva $t^{\prime}$ ] -áю, -аешьзакрыть, -кро́ю, -кро́ешь, cover, close.

заплатить see платі́ть.

заръзывать [zarєzыvat'] -аю, -аешь-

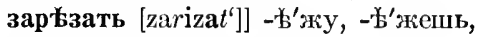
tear down, slaughter.

затьмь [zatem] after that, then.

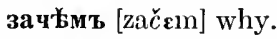

заходить [zaxadit'] -жу́, 'дншь-зайти

[zajti] зайдý, -дёшь (-шёлъ, -щла́,ó)

go, visit.

звукъ [zvuk] sound. зданіе [zdanijø] building.

здоровый [zdarovыj] cp. - - b'e, healthy. здравстовать [zdrastvavat'] -вую, -ешь

be well; здра́вствуйте how are you. зд'веь $[z d \mathbf{e} s]$ here.

зеркало [zerkala] $p l$. - ' mirror.

зима [zima] as., $n p$. '- winter.

злой [zloj] $p r$. золъ, зла, bad, evil.

злость [zlost'] $f$. wickedness.

знать [zna $t^{\prime}$ ] -áю, -а́ешь, know.

значить [znacit'] 'чу, 'чншьь, mean.

зоря [zora] dawn.

зубной [zubnoj] tooth-.

зубь [zup] $g$-ip. - ${ }^{\prime}$ tooth.

И [i] and.

и. ... и both.... and.

ива [iva] willow.

играть [igrat'] -áю, -а́ешь-по-, с-, play. изба [izba] $p l$. '- peasant's hut.

пзу чать [izuča $\left.t^{\prime}\right]$-а́ю, -а́ешь一-изучить

[izučit $\left.t^{\prime}\right]$-чý, 'чншь learn.

II3ъ [is, iz] prep. w. gen. out of.

пли [ili] or.

имя [i $m a$ ] $13 a$ name.

искать [iskat'] ищу́, и́цешь-по- seek.

искренный [iskrinnыj] $p r$. -ненъ, ¿-a, sincere.

итті [i $t$ i] иду́, пдёшь-по-go; see also ходи́ть.

Каждый [každыj] each, every.

казать [kazat'] кажу́, 'жешь-по-show; -cя seem.

каковой [kakavoj] pr. -о́въ, á, ó, б́ of what kind, appearance, etc.

какой [kakoj] which, what kind.

какъ [kak] how.

капать [kapat'] 'плю, 'плешь-заdrip, drizzle.

каранда шъ [karandaš] - ${ }^{\prime}$ pencil.

карманъ [karman] pocket.

картина [kartina] picture.

картинка [kartinka] little picture.

кафедра [kafidra] desk.

квартира [kvartira] dwelling, residence.

кладовая [kladavaja] adj. decl. storeroom.

классный [klasnыj] class-. 
класть $[$ klast'] кладу́, -дёшь (клаль) 一положить [palažït'] -жу́, 'жишь lay, put.

книга [kniga] book.

ковёръ [kavor] -', gs. ковра́ carpet.

когда $[\mathrm{ka \gamma da}]$ when.

кое-гд古 [kоj $\varepsilon \gamma d \varepsilon]$ somewherc.

кое-какъ [kojєkak] somehow, in some way.

козлёнокъ [kazlonak] $p l$. козля́та,

If 16,4 young goat.

колесо [kaliso] $p l$. — ' - (колёса) wheel.

комната [komnata] room.

комодъ [kamot] bureau, dresser.

кора [kara] bark, crust.

кормить [karmit'] -млю́, 'мишь-наfeed.

который [katorыj] which, who.

коть [kot] - ' (tom-) cat.

кофе [kof $\varepsilon]$ indecl. neut. coffee.

кресло [kreslo] armchair.

крестьянинъ [kristani $n] p l$. -я́не, farmer. крестьянство [kristanstvo] peasantry.

кричать [kricat'] -чý, -чи́шь-3a- and

крикнуть [kriknut'] 'ну, 'нешь, сrу. кровавый [kravavыj] bloody.

кровать [kravat'] $f$. bed.

кровь $[\mathrm{kro} f] f$. blood.

кром $\mathbf{6}$ [kroms] prep. w. gen. aside from.

круглый [kruglыj] $p r . f .-a ́, c p .-$-ъ'e round.

кружокъ [kružok] -' (-жкá) little circle, group.

крыть [krыt'] кро́ю, -о́ешь - по-cover. кры ша [krыša] roof.

кто [xto] โ 20 who.

кто-нибудь, кто-то [xto-nibut $t^{t}$, xtoto] whoever.

куда [kuda] where, whither.

кузне цъ [kuznвts] -' smith.

кузни ца [kuznitsa] smithy.

кулакъ [kulak] - ' fist.

кусокъ [kusok] gs. куска́, - ${ }^{\prime}$ piece.

кухня [kuxna] gp. ку́хонь or -онъ kitchen.

ку шанье [kušï $n$ є] food, meal.

ку шать [kušìt $\left.t^{\prime}\right]$ 'аю, 'aепь-no- eat.

къ $[\mathrm{k}, \mathrm{g}, \mathrm{x}]$ prep. w. dat. to.
Лёгкій [loxkыj] pr. лёгокъ, легка́, 6 , й, $c p$. ле́гче, легча́йmiї light.

ледяной [lidmoj] icy.

лежать [lizat $\left.t^{\prime}\right]$-жý, -жи́шь-no- lie.

лечь sеe ложи́ться.

ли [li] interrog. particle.

Juctr $[$ list $]$-' leaf.

лить $\left[l i t^{\prime}\right]$ лью, льёшь-по- pour.

ли цемърный [litsïmєrnыj] hypocritical.

ли шь [liš] only.

ложечка [ložička] little spoon.

ложиться [lažitsa] -жу́сь, -жкі́шьсялечь [leč] ля́гу, ля́жешь, ли́гутъ (лёгъ, легла́, ó, и́) lie down.

ложка [loška] spoon.

ломать [lamat $t^{\prime}$-áю, áешь-c- break.

лугъ [luk] $p l$. - $^{\prime}$ meadow.

луч шій [lučij] best.

львый [lвvыj] left.

львсь $\left[l_{\varepsilon s}\right] p l$. - $^{\prime}$ forest, woods.

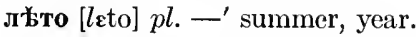

любить [lubit $\left.t^{t}\right]$-блю́, 'бпшь-по- love.

люди [lud $d \mathrm{i}] \quad m . p l .$, gen. люде́й, -' people.

Маленькій [malinkыj] small, little.

мало [malo] little.

малютка [malutka] $m$. and $f$. little child.

масло [maslo] butter.

мать [mat'] 13 mother.

мгла [mgla] fog, mist.

медленно [medlinno] slow.

между [mعždu] prep. $w$. instr. between.

мерцать [mirtsat $\left.t^{\prime}\right]$-а́ю, -а́ешь shine dimly.

метать $\left[m i t a t t^{\prime}\right]$-áю, -а́ешь or мечý,

-'чешь-метну́ть,- ну́, -нёшь throw.

мимо [mimo] prep. w. gen. past.

минута [minuta] minute.

міръ [mir] $p l$. - $^{\prime}$ world.

младенецъ [mladenits] gen. -нца little child.

много [mnogo] $w$. gen. much, many.

могучій [magučij] powerful.

мой [moj] ๆ $18 \mathrm{my}$.

молить [malit $\left.t^{\prime}\right]$-лю́, 'лишь-по-рray.

молоко [malako] milk. 
молчать [malča $\left.t^{\prime}\right]$-чý, -чи́шь-за- be silent.

морь [mor] plague.

мочь [тос̆] могу́, 'жешь (могъ, могла́, 6, и́)-no- can.

мудре цъ $[\operatorname{mud} r \varepsilon t s]-{ }^{\prime}$ wise man.

мужикъ [mužik] -' peasant.

мужичокъ [mužičok] gen. -чка́, -', dem. of мужи́къ.

мыть [mы $\left.t^{\prime}\right]$ мо́ю, -ешь--no- wash.

мҺжъ $[m \varepsilon \check{s}]=$ м'ъ'жду, ме́жду.

м.'̈ль [ $m \varepsilon \mathbf{l}]$ soap.

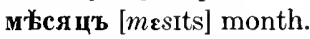

мясо [maso] meat.

Ha [na] prep. w. dat. and acc. on, upon. наварирать [navarivat $t^{\prime}$ ] -аю, -аешьнававить [navarit'] -pю́, -pи́mь brew. навстр б̆y [nafstreču] against, to meet. надо [nado] necessary; мн в н. I must.

над丸вать [nadivat $t^{\prime}$ ]-а́ю, а́ешь-надъть

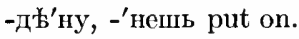

названіе [nazvanije] name.

называться [nazыvatsa] -а́юсь, -а́ешься be called.

найти see находи́ть.

наконецъ [nakancts] at last.

нам' [nam] (dat.) us.

нароботаться [narabotatsa] -аюсь, -аешься work enough.

народъ [narot] nation, people.

насаливать [nasalivat $t^{\prime}$ - аю, -аешьнасолить [nasalit'] -лю́, -ли́шь salt; make enemies.

насъ [nas] (acc.) us.

находить [naxadit'] -жу́, 'дишь-найти [najti] -ду́, -дёшь (-шёлъ, á, б, и́) find; -ся be found, be located.

начало [načalo] beginning.

начи нать [načina $\left.t^{\prime}\right]$-а́ю, -а́ешь-начать [načat'] -чну́, -чнёшь (на́чалъ, á, о, и) begin (trans.); -ся begin (intrans.).

наłзжать [najizat'] -áю, -а́ешь-наł хать [naj єxat $\left.t^{\prime}\right]-b^{\prime}$ ду, -дешь meet.

нађсться[ najestsa] see беть eat enough. не $[n \varepsilon, n \mathrm{i}]$ not.

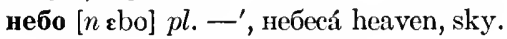

недъля [nidela] week.

некогда [ $n \varepsilon k a \gamma d a]$ мн's I have no time. нельзя [nilza] it is impossible, one cannot.

нести $[n$ isti] несу́, -сёшь-по- (нёсъ, несла́, ó, ú) carry.

ни . . . ни $[n \mathbf{i}]$ neither. . . nor.

нива [ $n$ iva] field.

никакой [nikakoj] of no kind, no.

никто [nixto] 122 no one.

но [no] but.

новый [поvыј] pr. $f$. -á, new.

ножикъ [nožik] pocket-knife.

ножь [noš] -' knife.

носить [nasit'] -шý, 'спшь-no-wear.

ночь [nос̌ $g$-ip. -, f. night.

нy [nu] now, well.

нуженъ [nužĩn] -жнá, -жно necessary; MH' $\mathrm{H}$. I must.

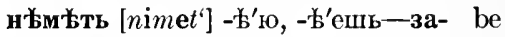
silent.

нъсколько [ $n$ eskalko] $w$. gen. a few.

н安ть $[n \varepsilon t]$ no.

$\mathbf{O}[\mathbf{o}$, a] prep. w. loc. [объ, обо] about. оба [oba] decl. like два, I 28 both.

обдирать [abdirat'] -а́ю, -а́шь-ободрать [abadrat $t^{i}$ ] обдерý, -ёшь tear to pieces.

обрадоваться seе ра́доваться.

образъ [obras] picture; каки́мъ б-омъ in what manner.

об щій [ор ščij] common, general; въ обцемъ all together.

объясненіе [abjısnenij $\varepsilon$ ] explanation.

объяснять [abjısnat'] -я́ю, -я́ешь-объ-

яснить [abjısnit $\left.t^{\prime}\right]$-ю́, -и́шь explain.

обыкновенно [abыknavenno] usually.

объдать [abedat'] -аю, -аешь-nо- eat dinner.

объ щать [a $b i$ šča $\left.t^{\prime}\right]$-а́ю, -а́ешь一-поpromise.

огонёкъ [aganok] -' gen. -нькá little flame.

одинъ [adin] ๆ 23 one.

одноколка [adnakolka] buggy.

одъвать [adivat'] -а́юсь, -аешь-од‡ть [adet $\left.t^{*}\right]$ од $\dot{b}^{\prime}$ ну, -'нешь dress. 
озимый [аzіmыj] winter (-grain). окно [akno] $p l . '-, g p$. бконъ window. около [okalo] prep. w. gen. around. onopa [apora] support.

опять [a $p$ a $\left.t^{\prime}\right]$ again.

осень [оsin] $f$. autumn.

остальной [astalnoj] remaining. острый [ostruj] $p r$. остёръ, á,ó,и́ sharp отвъть [atvet] answer.

отвъ чать [atvicat'] -а́ю, -а́ешь-отвłтить [atvetit'] 'чy, 'тишь answer.

отдыхать [addыxa $t^{\prime}$ ] -áю, -а́ешь-отдохнуть [addaxnut $t^{6}$ - -ну́, -нёшь rest. отецъ [atsts] -' gs. отца́ father.

открывать [atkrыvat'] -áю, -а́ешь一от-

крыть [atkrы $t^{\prime}$ ] -кро́ю, -кро́ешь open. оттого [attavo] therefore, for that reason. оттуда [attuda] from there.

отчаяніе [atčajınijє] despair.

отчего [atčivo] why.

отъ [ot, at] prep. w. gen. from, of.

отыскивать [atbskiva $t^{\prime}$ ] -аю, _-аешь-

отыскать [atыskat'] отыцу́, 'цешь seek, hunt for.

охотиикъ [axotnik] hunter.

очень [ос̌i $n]$ very.

о шибка [ašïpka] mistake.

Палка [palka] stick, pointer.

пальчикъ [palčik] little finger.

парить [parit'] -рю́, pи́шь hang, hover. первый [регvыj] first.

переводить [pirivadit'] -ду́, 'дишьперевести [pirivisti] -дý, -дёшь translate.

передняя [pire $d n$ rja] $a d j$. decl. anteroom, reception room.

передт [perit] prep. w. instr. in front of. перо [piro] $p l$. '-, пе́рья pen, feather. печатный [pičatnыj] printed.

печь $[p$ ес̌ $]$ stove.

писанiе [pisanij $\varepsilon]$ writing.

писать [pisat $\left.t^{\prime}\right]$ пишу́, 'шешь-на-write. пить $\left[p \mathbf{i} t^{t}\right]$ пью, пьёшь-вы- drink.

плакать [plakat'] пка́чу, -чешь-заweep.

платить [platit'] плачу́, 'тишь-3аpay. плохой [plaxoj] $p r .{ }^{\prime}-, f$. á, bad, $c p$. пло́ше.

Iо [po, pa] prep. w. dat., acc., loc. on.

побить, побльдньть, etc.; see бить, etc. погребъ [pogrip] $p l .{ }^{\prime}$ cellar.

поддержка [padderška] support, help.

поднимать [padnimat'] -áю, -а́ешьподнять [padnat'] -ниму́, -мёшь (-Јъ á, o, 1г)) lift, raise.

подсматривать [patsmatrivat'] -аю, -аешь- подсмотрбть [patsmatre $t^{s}$ ] -рю́, 'ришь observe.

подъ [pot, pat] prep. w. acc. and instr. under, below.

пожалуйста [pažalsta] please.

поздно [pozno] late.

покамъсть [pakamist'] for the time being.

поле [ро $l \varepsilon] p l$. - $^{\prime}$ field.

половина [palavina] half.

полчаса [palčrsa] half an hour.

поль [pol] $l s$. (на) $-\dot{y}$, floor.

помнить [pomnit'] 'мню, 'мнишь-сremember.

поникать [panikat $t^{\prime}$-áю, -áeшь一-поникнуть [paniknut'] -ну, -нешь droop.

понимать [panimat'] -а́ю, -а́ешь-понять [panat $t^{t}$ поймý, -мёшь (по́нялъ á, o, 11) understand.

послови ца [paslovitsa] proverb.

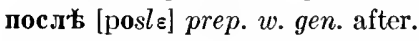

посылать [pasыlat'] -а́ю, -а́ешь-по-

слать [pasla $t^{\prime}$ ] пошлю́, -шлёшь send. потокъ [patok] brook, stream.

потолокъ [patalok] $s g .-^{\prime}, p l .-^{\prime}-$ (потолка́-потб́лки) ceiling.

потому что [patamu što] because.

почему [pačimu] why.

почти [pačti] almost.

по шлость [pošlast'] silliness.

почесать [рас̌isat $t^{\prime}$ ] -шý, 'шешь scratch. правдивый [pravdivыj] just, sincere.

правый [pravыj] $p r . f$. á, $c p$. - $\mathfrak{b}^{\prime} \mathrm{e}$ right.

прежде [prežd $d$ ] beforehand, first.

прекрасный [prikrasnыj] beautiful.

при [рri] prep. w. loc. at, near. 
приготовлять [prigatavla $\left.t^{\prime}\right]$-я́ю, -я́ешь -приготовнть [prigato $\left.v \mathbf{i} t^{\prime}\right]$-бвлю, -овишш make ready, prepare.

придумывать [pridumыvat'] -аю, -аешь пршдумать [pridumat'] -аю, -аешь think out, invent.

приказывать [prikazыvat'] -аю, -аешь приказать [prikazat'] -жу́, -жешь command.

принадлежать [prinad $\left.l i z ̌ a t^{t}\right]$-áю, -áешь belong.

принимать [prinimat $t^{\prime}$-а́ю, -а́ешьпринять [prinat $\left.t^{\prime}\right]$-нцмý, -мёшь (при́няльъ, á, o, н) accept.

прнпасъ [pripas] victuals, food.

приходить [prixadit'] -жý, 'дишь-прійти [priti] прійду́, -дёшь арproach; мн'́ прихо́дится I must.

причёсывать [pričosыva $t^{*}$ ] -аю, -аешь -причесать [pričisat $\left.t^{\prime}\right]$-пу́, 'шешь comb.

пріёмная [prijomnaja] adj. decl. reception room, parlor.

пріঝзжать [prijižat $\left.t^{*}\right]$-áю, -а́ешь-прі-

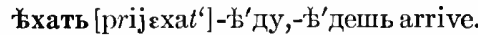
про [pro, pra] prep. w. acc. for, about.

продавать [pradavat']-даю, -ёшь-продать [proda $t^{\prime}$ ] -дамъ, -да́шь sell.

продолжать [pradalžat'] -а́ю, -а́ешь continue.

проза [proza] prose.

произношеніе [praiznašenij $\varepsilon$ ] pronunciation.

проноситься [pranasitsa] -шу́сь, 'спшься-пронестись [pranistis] -несу́ся, -сёшься vanish.

пропадать [prapadat $t^{\prime}$-áı, -а́ешь—пропасть [prapast'] -дý, -дёпь (-па́лъ) spoil, ruin.

просшть [prasit $\left.t^{6}\right]$-шý, 'сишь-по- ask. простой [prastoj] $p r .^{\prime}-, f$. -á, $c p$. про́ще plain.

прочитывать [pračitыvat'] -аю, -аешь -прочесть [pračest'] -чту́, -чтёшь read (aloud).

прочи цаться [pračisčatsa] -а́юсь, -áeшься-прочиститьсл [pračistitsa] -Іцу́сь, 'стпшься clear up. прыгать [prыgat'] 'аю, 'аешь-прыгнуть [prыgnut $t^{t}$ ], -ну, -непь play.

про щать [praščat'] -áю, -а́ешь--простить [prastit'] -щý, 'стишь forgive; проща́й, -те good-bye.

прямо [pramo] straight.

пускать [puskat'] -áю, -а́ешь-пустить пущу́, 'стишь let loose, release.

пустой [pustoj] empty, vain; пусто́e! nonsense!

пытать [pыtat $t^{\prime}$-а́ю, а́ешь-по- try.

пялить $\left[p a l i t^{\prime}\right]$ 'лю, 'лишь-рас- open wide.

Работа [rabota] work.

работать [rabotat'] 'аю, 'аешь-поwork.

рабочій [rabočij] (день) work day.

радоваться [radavatsa] -аюсь, -аешься - об- be glad.

радъ [rat] glad.

развъ [razve] perhaps.

раздуміе [rázdumije] hesitation, indecision, uncertainty.

раздъленіе [razdilenij $\varepsilon$ ] division.

раздћлять [razdilat $t^{\prime}$-я́ю, -я́епь-pas-

дъллить [razdelit'] 'лю, 'лшшь divide. разъ [ras] once.

растить [rastit‘] paщý (рощу́) -сти́шь 一ви́- raise, bring up.

ребёнокъ [ribonak] $p l$. реб́я́та, ๆ 64,4 , boy, child.

porъ [rok] $p l .-^{\prime}$, porá, horn.

родина [rodina] home, country.

ропоть [ropat] murmur.

рощу, see pactítь.

pyбaxa [rubaxa] shirt.

рубить [rubit $\left.t^{\prime}\right]$-блю́, 'бишь-на- cut.

pyкa [ruka] as., np. '- hand.

русскій [ruskыj] Russian.

ручей [ručej] gs. ручья́, $p l$. ручьи́ brook, creek.

Садиться [saditsa] сажу́сь, сади́шьсясћсть [sest'] ся́ду, 'дешь sit down.

садъ [sat] $p l$. -' garden.

салфетка [salf ftka] napkin.

сахаръ [saxar] gs. -y sugar. 
свёртывать [svortыva $t^{\prime}$ ] -аю, -аешьсвернуть [svirnut $\left.t^{\prime}\right]$-ну́, -нёпь turn aside.

свиданіе [svidanijs] sceing again, revoir. свобода [svaboda] freedom.

свободный [svabodnыj] free.

сводить [svadit'] -жу́, 'дишь-свести [sristi] -дý, -дёшь lead away.

свътить [svitit ] -чý, 'тишь shine.

св‡ пивать [svєšïva $t^{\prime}$ ] -аю， -аешьсвъсить [svisit $\left.t^{\prime}\right]$ [svesit'] св'b'шу, 'cinш hang down, lower.

святой [svitoj] holy, sacred.

сдълать, see дъ'лать.

сегодня [sivo $d n$ a] today.

семейство [simejstvo] family.

семья [simja] $n p$. '- (се́мьи) family.

сердиться [sirditsa] сержу́сь, се́рдипься-pas- be angry:

сердце [serts $\varepsilon$ ] $p l .-^{\prime}$ heart.

сидъть [side $\left.t^{\prime}\right]$ сижу́, -ди́пь-по- sit.

сильный [silnыj] $p r$. си́ленъ or силёнъ á, o, и; $c p$. -b'e strong.

сказать, sеe говори́ть.

скамейка [skamejka] bench.

скатерть [skatirt'] g-ip. - ' tablecloth.

сколько [skolko] w. gen. how much, how many.

скоро [skoro] quick, soon.

скучный [skučnыj] pr. f. -á, cp. -ъ'e, tedious; мн

слава [slava] glory.

сладкій [slatkыj] $p r . f$. -á, cp. сла́ще, сладча́йшій, sweet.

слеза [sliza] $p l . '$ - (слёзы) tear.

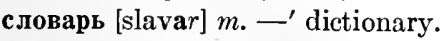

слово [slovo] $p l .{ }^{\prime}$ ' word.

c ग़yra [sluga] $p l$. ' - servant.

служить [služitit'] -жу́, 'жииьь-поserve.

случаться [slučatsa] -а́ется-случиться [slučitsa] случи́тся happen.

слу шать [slušì $\left.t^{\prime}\right]$-аю, -аешь-поlisten.

слы шать [slыšït'] 'mу, 'шишь-уhear.

слґзать [sliza $t^{*}$ ] -а́ю, -а́ешь一слЊзть [slest'] 'зу, 'зешь climb down. смотръть [smatret'] -трю́, -'трніпьno- look.

смысль [smы $l$ l] sense, meaning. $m$.

снимать [snimat $\left.t^{\prime}\right]$-áю, -а́ешь-снять [snat'] снимý, -ёшь (снялъ, a) take off.

собака [sabaka] dog.

созывать [sazыvat'] -áю, -а́ешь-coзвать [sazvat'] -зову́, -ёшь call together, summon.

собирать [sabira $t^{*}$ ] -áю, -а́епь-собрать [sabra $t^{\prime}$ ] -беру, -pёшь gather.

совер шиваться [savєršivatsa] -а́етсясовер шиться [saviršïtsa] -и́тся come to pass, happen.

сомнъніе [somnenije] doubt.

сонный [sonnыj] asleep, sleeping.

составлять [ sastavlat'] -áю, -а́ешьсоставить [sasta $\left.v i t^{\prime}\right]$ 'влю, 'вишь form.

состоять [sastajat $t^{\prime}$-ю́, -и́пь consist.

сосъдъ [sasst] neighbor.

спальня [spalna] bedroom.

спасать [spasat'] -а́ю, -а́ешь-спасти

[spasti] -cý, -cëmb save.

спасибо [spasibo] thanks.

спать $\cdot\left[\mathrm{spa} t^{\prime}\right]$ сплю, спишь-no- sleep.

сперва [spirva] first.

спорить [sंporit'] -рю, -рншь-поquarrel.

спра шивать [sprašïva $\left.t^{\prime}\right]$-аю, -аешьспросить [sprasit'] -шý, 'сншь ask.

среди [sridi] prep. w. gen. in the midst. средство [sretstvo] means.

стаканъ [stakan] glass.

старикъ [starik] -' old man.

старичокъ [staričok] -', gen. -чка́, dim. of старі́къ.

старый [starыj] pr.f. -á, cp. - b'e old. стать [sta $t^{\prime}$ ] ста́ну, 'нешь become, begin. стая [staja] pack.

стиль [stil] $m$. style, calendar.

стоить [stoil'] -о́ю, -о́ишь cost.

столовая [stalovaja] adj. decl. diningroom.

столъ [stol] —' table.

столько [stolko] so much, so.

стоять [stajat $t^{\prime}$ ] -ю́, -и́шь-по- stand. 
стра шный [strašndj] $p r . f .-a ́, c p$. - ‘'e terrible.

стуль [stul] $n p$. сту́лья, ๆ 14,5 chair. стьниа [stina] as., $n p$. '- wall.

сударь [sudar] lord, sir.

судьба [sud'ba] $n p$. ' - fate, destiny.

супъ [sup] soup.

счастливый [ščılivыj] happy.

счастье [ščast $\varepsilon$ ] happiness, good luck.

съ [s, z] prep. w. instr. with, w. gen., from.

съъдать [sjedat'] 'даю, 'даешь-съъсть [sjest $t^{\prime}$ - бмъ, -бшь eat up, devour.

съఓстной [sjisnoj] eatable; с-и́е припа́сы victuals, foodstuffs.

сынъ [sыn] $p l$. сыновья́, ๆ $14,5 a$ son. сыпать [sыраt'] 'плю, 'плешь-поscatter, pour.

съдой [sidoj] gray.

съно [sєno] hay.

състь, sеe садиться.

съять [sejat $\left.t^{\prime}\right]$ сь'ю, ешь-по- sow.

Такой [takoj] such, that.

такъ [tak] so.

тамъ [tam] there.

тарантасъ [tarantas] traveling coach.

тарелка [tarclka] plate.

телёнокъ [tilonak] $p l$. -я́та,' 16,4 calf.

тёмный [tomnыј] pr. -менъ, мна́, б́, и́;

-6'e dark, obscure.

тепrepb $[t i p e r]$ now.

тёплый [toplыј] pr. -пель; -пла́, о́, и́;

$c p$. - b'e warm.

тетрадь $\left[t\right.$ itra $\left.t^{\prime}\right] f$. notebook.

тихій [tiхыј] $c p$. ти́ше quiet, slow.

To [to] that.

тогда $[\operatorname{ta} \gamma \mathrm{da}$ ] then.

тоже [tož $\varepsilon$ ] also.

толкъ [tolk] sense.

только [tolko] only.

тонкій [tonkыj] $p r . f$. -á, cp. то́ньше, тонча́йшiй thin.

тот' [tot] then.

тотчасъ [tatčas] immediately.

тройка [trojka] team of three horses.

трудный [trudnыj] pr. -денъ, -дна́, о, и

$c p$. $-\mathrm{w}^{\prime} \mathrm{e}$ difficult. трудъ [trut] - ${ }^{\prime}$ effort, difficulty. трясти [tristi] -cý, -сёшь-по- tremble. туалетъ [tualst] toilet, dressing. туда [tuda] there.

тупой [tupoj] $p r .-^{\prime}$ dull.

туть [tut] then.

туча [tuča] cloud.

тънистый [tinistыj] shady.

тягостный [tagasnыj] burdensome, sad.

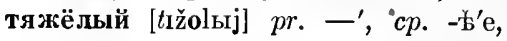
heavy.

тянуть $\left[t_{\mathbf{n} u} t^{\prime}\right]$ ну́, 'нешь-по- draw.

$\mathbf{y}[\mathrm{u}]$ prep. w. gen, at.

убирать [ubirat $t^{6}$-а́ю, -а́ешь-убрать [ubrat'] -pý, -pëшь (see $59 a$ ) take away, harvest.

увы [uvы] alas!

уголъ [ugal] —' (loc. въ углу́) corner.

ужасъ [užïs] terror.

уже [užє] (ужо́, ужъ) already.

ужинать [užĩnat'] -аю,-аешь eat supper.

узнавать [uznava $t^{\prime}$ ] -аю́, -аёшь-узнат

-а́ю, -а́ешь hear, learn.

укрывать [ukrыvat'] -áю, -а́ешьукрыть [ukrыt $t^{\prime}$ ] -о́ю, -о́ешь cover. умирать [umirat $\left.t^{\prime}\right]$-áı, -а́ешь-умереть [umiret'] умру́, -рёшь die.

умный [umnыј] $p r .-^{\prime}$ (умёнъ, умна́) $c p$. -b'e sensible, clever.

унимать [unimat $t^{\prime}$-а́ю, -аешь一унять [unat'] уймý, уймёшь (уня́лъ, á, ó, и́) stop, silence.

уносить [unasit'] -шу́, 'сишь-унести́ [unisti] -cý, -cëшь carry away, take.

упадать [upada $t^{\prime}$ ] -áю, -а́ешь-упасть [upast'] упаду́, -дёшь (упа́лъ) fall.

урокъ [urok] lesson.

устланъ [uslan] covered.

утренный [utrinnыj] morning-.

утро [utro] $p l$. - $^{\prime}$ morning.

утъ шать [utiša $\left.t^{\prime}\right]$-áю, -áeшь-уть' ши-

ть [utešit $\left.t^{\prime}\right]$ 'шy, 'шишь comfort.

yxo [uxo] np. ýmII, $g$-ip. - ' ear.

уходить [uxadit'] -жу́, 'дишь-уйти

[ujti] уйду́, -дёшь (ушёлъ, ушла́, $́$ ) go away.

учебникъ [učebnik] textbook. 
ученикъ [uс̌inik] -' student.

учени ца [učinitsa] student (girl).

учили ще [učilišč $\varepsilon$ ] school.

учитель [učitil] $p l$. -ІІ or -я́, I 14, 5 teacher.

учить [ucit $\left.t^{t}\right]$ учу́, у́чишь-на- teach; -ся study, learn.

Фамплія [familija] family name.

Хлғббъ [хlєp] $p l$. 'ы bread; $p l$. -á grain. холмз [xolm] hill. $p l$. -'.

холодный [xalodnыj] $p r$. '-, -дна́, -ó, -b́r cold.

хоро шіиі [xarošij] $p r .-^{\prime} \operatorname{good}, c p$. лу́ чाше.

хоть $\left[\operatorname{xot}^{\prime}\right]$ although.

хот'́十ть [xate $\left.t^{\prime}\right]$-чý, 'чешь, за- will.

хранить [xrani $\left.t^{\prime}\right]$-ню́, -ни́́шь-соkeep, store.

Царскій [tsarskыj] Tsar's. царство [tsarstvo] empire.

царь [tsar] —' Tsar.

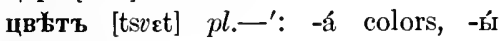
flowers.

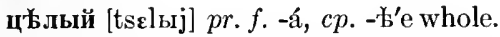

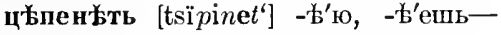
o- become rigid, congeal.

Yaï [čaj] gen. 'y tea. pl. -'.

часто [často] often.

часть $\left[\check{c} \mathbf{a s t} t^{\prime}\right] g-i p .-^{\prime}$ part.

часъ [čas] -' time, hour.

ча шка [čaška] cup.

человъкт [čilavek] pl. лю́ди man.

чёрный [čornыj] pr. -ренъ, -рна́, o, и black.

чесать [čisat']-шý, 'шешь comb; поscratch. чинить [činit'] -ню́, 'нпшь-по- o- do, make, repair, sharpen.

число [čislo] $p l$. ' - number, date.

чнстить [čistit'] 'іцу, 'стишь-по-, выclean.

чистый [čistыj] $p r . f .-a, c p$. чи́цце, clean.

читать [čitat $\left.t^{\prime}\right]$-áю, -áешь-по- read.

что [što] what, I 20.

чтобы [štobы] so that, in order that.

что-нибудь [što-nibut $t^{\prime}$ ] whatever.

чуять [čujıt'] чу์ю, -ешь-no- feel.

IIIan ka [šapka] hat.

широкій [šïrokыj] $p r .-^{\prime}, c p$. ши́ре, широча́ї шій broad, wide.

шкапъ [škap] $l s$. въ ш-ý, $p l$. - $^{\prime}$ cupboard.

школа [škola] school.

шкура [škura] fur, skin.

шмыгать [šmыgat'] -аю, -аешьшмыгнуть [šmыgnut'] -ну, -нешьь slip.

шопотъ [šopat] whispering.

Щётка [ščotka] brush.

щёточка [ščotačka] little brush.

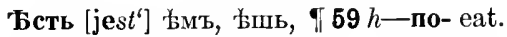

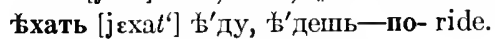

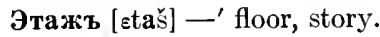
этотъ [ctat] this, I 19.

Я [ja] $17 \mathrm{I}$.

ягнёнокъ [jignonak] -я́та, ๆ 14, 5 lamb. языкъ [jzыk] -' tongue, language. яй цо [jitso] $p l$. '-, gp. яи́ц'ь, egg. лровой [jıravoj] summer- (grain). я щиикъ [jaščik] drawer. 




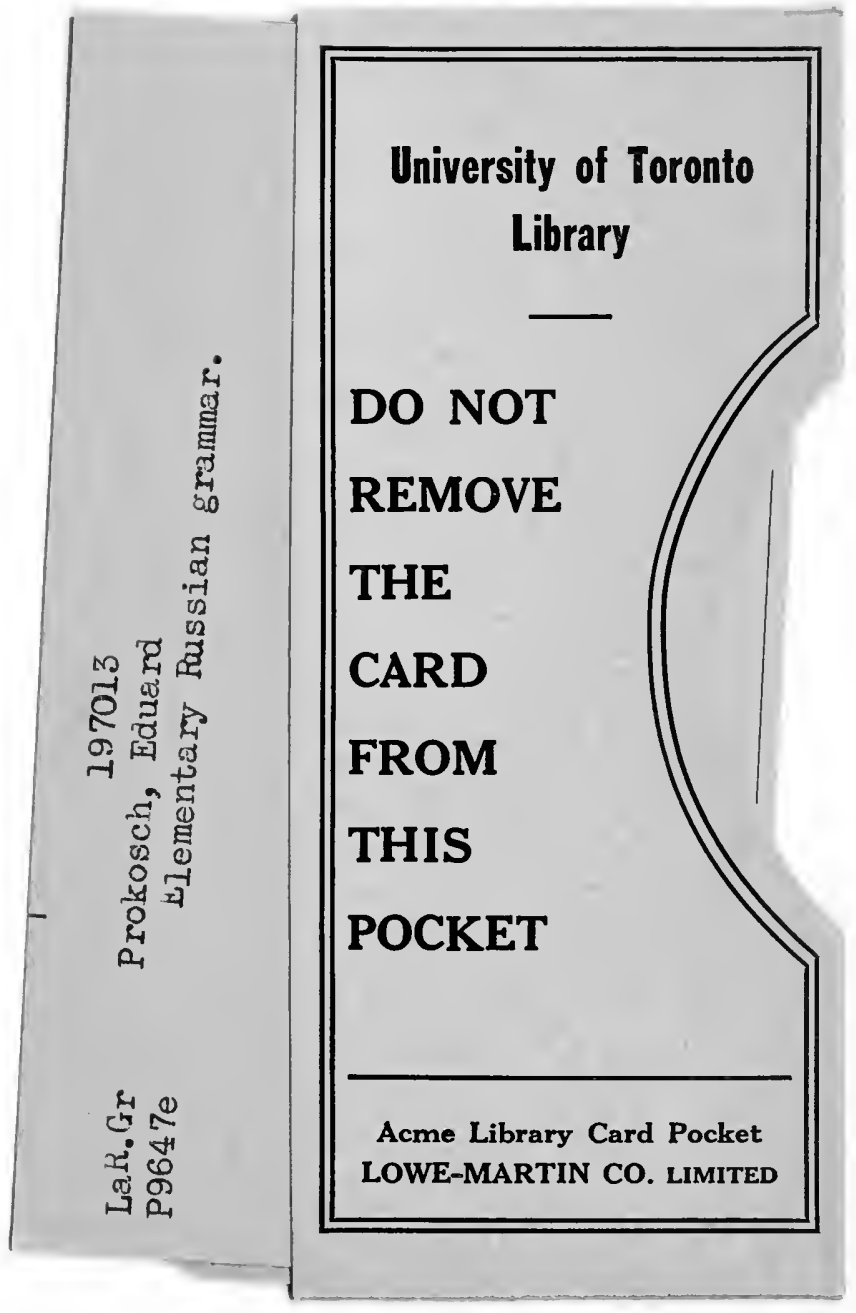


